\title{
The Potential of Secondary Metabolites from Plants as Drugs or Leads against Protozoan Neglected Diseases-Part III: In-Silico Molecular Docking Investigations
}

\author{
Ifedayo Victor Ogungbe ${ }^{1}$ and William N. Setzer ${ }^{2, *}$ \\ 1 Department of Chemistry and Biochemistry, Jackson State University, Jackson, MS 39217, USA; \\ ifedayo.v.ogungbe@jsums.edu \\ 2 Department of Chemistry, University of Alabama in Huntsville, Huntsville, AL 35899, USA \\ * Correspondence: wsetzer@chemistry.uah.edu; Tel.: +1-256-824-6519 \\ Academic Editor: Thomas J. Schmidt \\ Received: 16 September 2016; Accepted: 12 October 2016; Published: 19 October 2016
}

\begin{abstract}
Malaria, leishmaniasis, Chagas disease, and human African trypanosomiasis continue to cause considerable suffering and death in developing countries. Current treatment options for these parasitic protozoal diseases generally have severe side effects, may be ineffective or unavailable, and resistance is emerging. There is a constant need to discover new chemotherapeutic agents for these parasitic infections, and natural products continue to serve as a potential source. This review presents molecular docking studies of potential phytochemicals that target key protein targets in Leishmania spp., Trypanosoma spp., and Plasmodium spp.
\end{abstract}

Keywords: Leishmania; Trypanosoma; Plasmodium; natural products drug discovery

\section{Introduction}

Parasitic protozoal diseases continue to be a cause of considerable morbidity and mortality, particularly in underdeveloped countries around the world. These diseases include malaria [1], Chagas disease [2], human African trypanosomiasis [3], and leishmaniasis [4]. Current chemotherapeutic options for these neglected diseases can have severe side effects, may be ineffective, or even non-existent, and in cases where drug treatment is available, resistance is emerging [5-8]. Thus, there is a need to discover and develop of new chemotherapeutic agents for these parasitic infections. Natural products have been served as important leads for drug development and databases of natural products provide a convenient source for virtual screening against drug targets [9], including parasitic protozoal diseases [10-12]. Natural products offer important complementary opportunities in drug discovery: (a) They occupy different regions of biologically relevant chemical space [13], including abundant oxygen-containing functionalities (rarely nitrogen) and high degrees of chirality and complexity [14]; (b) although outside the "rule-of-five", numerous natural products have proven to be efficacious drugs [15]; (c) they have been optimized for activity, including active transport, by evolution [16]; and (d) natural products serve as lead structures for semisynthetic modification to improve activity, selectivity, or bioavailability [17]. In this review, we present in-silico efforts at natural product drug discovery for neglected parasitic protozoal diseases; molecular docking of phytochemical ligands with potential parasitic protein targets (Table 1). 
Table 1. Protein targets with three-dimensional structures available from the Protein Data Bank (PDB).

\begin{tabular}{|c|c|c|c|c|c|c|c|}
\hline \multirow{2}{*}{ Protein Target } & \multicolumn{7}{|c|}{ PDB Protein Structure } \\
\hline & L. donovani & L. infantum & L. major & L. mexicana & P. falciparum & T. brucei & T. cruzi \\
\hline $\begin{array}{l}\text { Adenine phosphoribosyl } \\
\text { transferase (APRT) }\end{array}$ & $\begin{array}{l}\text { 1QB7, 1QB8, } \\
\text { 1QCC, 1QCD [18] }\end{array}$ & & & & & & \\
\hline Adenosine kinase (AK) & & & & & & 2ХTB, 3ОTX [19], 4N09 [20] & \\
\hline $\begin{array}{l}\text { Adenoylsuccinate synthetase } \\
\text { (AdSS) }\end{array}$ & & & & & 1P9B [21] & & \\
\hline Aminopeptidase (Apase) & & & & & & 4EFD; 4FUK [22] & \\
\hline $\begin{array}{l}\text { Apical membrane antigen I } \\
\text { (AMA1) }\end{array}$ & & & & & 3SRI, 3SRJ, 3ZWZ [23] & & \\
\hline Arginase (ARG) & & & & $\begin{array}{l}\text { 4ITU, 4IU0, 4IU1, } \\
\text { 4IU4, 4IU5 [24] }\end{array}$ & 3MMR [25], 3SL0, 3SL1 [26] & & \\
\hline Arginine kinase (ArgK) & & & & & & & 2J1Q [27] \\
\hline $\begin{array}{l}\text { Aspartate aminotransferase } \\
\text { (AspAT) }\end{array}$ & & & & & $3 \mathrm{~K} 7 \mathrm{Y}[28]$ & & \\
\hline Autophagy protein 8 (Afg8) & & & & & 4EOY [29] & & \\
\hline Cathepsin B (CatB) & & & & & & $\begin{array}{l}\text { 3HHI [30], 3MOR [31], } \\
4 \mathrm{HWY}[32]\end{array}$ & \\
\hline Choline kinase (CK) & & & & & 3F18 [33] & & \\
\hline Cruzain & & & & & & & $\begin{array}{l}\text { 2AIM [34], 1F29, 1F2A, } \\
\text { 1F2B, 1F2C [35], 1ME3, } \\
\text { 1ME4 [36], 1U9Q [37], 2OZ2 } \\
\text { [38], 3HD3 [39], 3I06 [40], } \\
\text { 3IUT [41], 3LXS [42], 4BKL } \\
\text { [43], 1EWL; 1EWM; 1EWO; } \\
\text { 1AIM [44] }\end{array}$ \\
\hline Cyclophilin (Сур) & 2HAQ, 3EOV [45] & & 2HQJ [46] & & 1QNG [47] & & \\
\hline Cysteine synthase (CS) & & & 4AIR [48] & & & & \\
\hline $\begin{array}{l}\text { Deoxyuridine triphosphate } \\
\text { nucleotidohydrolase (dUTPase) }\end{array}$ & & & $\begin{array}{l}\text { 2CJE, 2YAY, 2YAZ, } \\
\text { 2YBO [49] }\end{array}$ & & $\begin{array}{l}\text { 1VYQ [50], 2Y8C [51], 3T60, } \\
\text { 3T64, 3T6Y, 3T70 [52] }\end{array}$ & $\begin{array}{l}\text { 4DK2, 4DK4, 4DKB, 4DL8, } \\
\text { 4DLC [53] }\end{array}$ & 1OGK, 1OGL [54] \\
\hline $\begin{array}{l}\text { Diadenosine tetraphosphatase } \\
\text { (DATP) }\end{array}$ & & & & & & 1QJC [55] & \\
\hline
\end{tabular}


Table 1. Cont

\begin{tabular}{|c|c|c|c|c|c|c|c|}
\hline \multirow{2}{*}{ Protein Target } & \multicolumn{7}{|c|}{ PDB Protein Structure } \\
\hline & L. donovani & L. infantum & L. major & L. mexicana & P. falciparum & T. brucei & T. cruzi \\
\hline $\begin{array}{l}\text { Dihydrofolate } \\
\text { reductase-thymidylate synthase } \\
\text { (HDFR-TS) }\end{array}$ & & & & & $\begin{array}{l}\text { 1J3I [56]; 3DGA [57]; 3QGT } \\
\text { [58]; 3UM8 [59]; 4DDR, } \\
\text { 4DP3, 4DPD, 4DPH [60] }\end{array}$ & 3QFX, 3QGT, 3RG9 [58] & $\begin{array}{l}\text { 2H2Q, 3CL9, 3CLB [61]; } \\
\text { 3HBB [62]; 3KJS [63] }\end{array}$ \\
\hline $\begin{array}{l}\text { Dihydroorate dehydrogenase } \\
\text { (DHODH) }\end{array}$ & 3C61 [64] & & $\begin{array}{l}\text { 3MHU, 3MJY [65]; } \\
\text { 3TQ0 [66]; 4EF8, } \\
\text { 4EF9 [67]; 3GYE, } \\
\text { 3GZ3 [68] }\end{array}$ & & $\begin{array}{l}\text { 1TV5 [69]; 3I65, 3I68; 3I6R } \\
\text { [70]; 3O8A [71]; 3SFK [72]; } \\
\text { 4CQ8, 4CQ9, 4CQA [73] }\end{array}$ & 2B4G [74] & $\begin{array}{l}\text { 3C3N [75]; 2E6D [76]; 2E68, } \\
\text { 2E6A, 2E6F, 2DJL, 2DJX [77]; } \\
\text { 3W1A , 3W1L, 3W1M, } \\
\text { 3W1N, 3W1P, 3W1Q, 3W1R, } \\
\text { 3W1T, 3W1U, 3W1X, 3W22, } \\
\text { 3W23, 3W2J, 3W2K, 3W2L, } \\
\text { 3W2M, 3W2N, 3W2U [78]; } \\
\text { 3W3O [79]; 3W6Y, 3W70, } \\
\text { 3W71, 3W72, 3W73, 3W74, } \\
\text { 3W75, 3W76, 3W7C, 3W7D, } \\
\text { 3W7E, 3W7G, 3W7H, 3W7I, } \\
\text { 3W7J, 3W7K, 3W7L, 3W7M, } \\
\text { 3W7N, 3W7O, 3W7P, 3W7Q, } \\
\text { 4JD4, 4JDB [80]; 3W83, } \\
\text { 3W84, 3W85 [81]; 3W86, } \\
\text { 3W87, 3W88 [82] }\end{array}$ \\
\hline $\begin{array}{l}\text { D-Tyrosyl-tRNATyr } \\
\text { deacylase (DTD) }\end{array}$ & & & & & $\begin{array}{l}\text { 3KNP, 3KNF, 3KO3, 3KO4, } \\
\text { 3KO5, 3KO7, 3KO9, 3KOB, } \\
\text { 3KOC [83]; 3LMT, 3LMU, } \\
\text { 3LMV [84]; 4NBI, 4NBJ [85] }\end{array}$ & & \\
\hline Enolase & & & & & & $\begin{array}{l}\text { 1OEP [86]; 2PTW, 2PTX, } \\
\text { 2PTY, 2PTZ, 2PU0, } \\
\text { 2PU1 [87] }\end{array}$ & \\
\hline $\begin{array}{l}\text { Enoyl acyl-carrier-protein } \\
\text { reductase (FabI = ENR) }\end{array}$ & & & & & $\begin{array}{l}\text { 1NHD, 1NHG, 1NHW, } \\
\text { 1NNU, 1VRW [88]; 1UH5, } \\
\text { 1V35 [89]; 1ZSN, 1ZW1, } \\
\text { 1ZXB, 1ZXL [90]; 2O2S, } \\
\text { 2O2Y [91]; 2FOI, 2NQ8, } \\
\text { 2OL4, 2OOS, 2OP0, 2OP1 } \\
\text { [92]; 3LSY, 3LT0, 3LT1, 3LT2, } \\
\text { 3LT4 [93]; 4IGE, 4IGF [94] }\end{array}$ & & \\
\hline Falcipain 2 (FP-2) & & & & & $\begin{array}{l}\text { 1YVB [95]; 2GHU [96]; } \\
\text { 2OUL [97]; 3BPF [98]; } \\
\text { 3PNR [99] }\end{array}$ & & \\
\hline
\end{tabular}


Table 1. Cont

\begin{tabular}{|c|c|c|c|c|c|c|c|}
\hline \multirow{2}{*}{ Protein Target } & \multicolumn{7}{|c|}{ PDB Protein Structure } \\
\hline & L. donovani & L. infantum & L. major & L. mexicana & P. falciparum & T. brucei & T. cruzi \\
\hline Falcipain 3 (FP-3) & & & & & 3ВРМ [98]; 3ВWК [38] & & \\
\hline $\begin{array}{l}\text { Farnesyl diphosphate } \\
\text { synthase (FPPS) }\end{array}$ & & & $\begin{array}{l}\text { 4K10, 4JZX, } \\
4 \mathrm{JZB}[100]\end{array}$ & & & $\begin{array}{l}\text { 2EWG, 2I19 [101]; 2P1C } \\
\text { [102]; 3DYF, 3DYG, 3DYH, } \\
\text { 3EFQ, 3EGT [103]; } \\
\text { 2OGD [104] }\end{array}$ & $\begin{array}{l}\text { 1YHL, 1YHM [105]; 3IBA, } \\
\text { 3ICK, 3ICM, 3ICN, 3ICZ, } \\
\text { 3ID0 [106]; 4DWB, 4DWG, } \\
\text { 4DXJ, 4DZW, 4E1E [107] }\end{array}$ \\
\hline $\begin{array}{l}\text { Ferredoxin-NADP+ } \\
\text { reductase (FNR) }\end{array}$ & & & & & 2OK7, 2OK8 [108] & & \\
\hline FK506 binding protein (FKBP35) & & & & & $4 J 4 N$ [109] & & \\
\hline $\begin{array}{l}\text { Fructose-1,6-bisphosphate } \\
\text { aldolase (ALDO) }\end{array}$ & & & & $\begin{array}{l}\text { 1EPX [110]; } \\
\text { 2QAP, 2QDG, } \\
\text { 2QDH [111] }\end{array}$ & $1 \mathrm{~A} 5 \mathrm{C}[112]$ & & \\
\hline $\begin{array}{l}\text { Glutamate dehydrogenase } 2 \\
\text { (GDH2) }\end{array}$ & & & & & 3R3J [113] & & \\
\hline $\begin{array}{l}\text { Glutathione peroxidase-like } \\
\text { enzyme } 1 \text { (GPX1) }\end{array}$ & & & & & & & 3EOU [114] \\
\hline Glutathione reductase (GR) & & & & & 1ONF [115] & & \\
\hline Glutathione $S$-transferase (GST) & & & & & $\begin{array}{l}\text { 1OKT [116]; 1PA3, } \\
\text { 1Q4J [117]; 2AAW [118] }\end{array}$ & & \\
\hline $\begin{array}{l}\text { Glyceraldehyde 3-phosphate } \\
\text { dehydrogenase (GAPDH) }\end{array}$ & & & & $\begin{array}{l}\text { 1GYP [119]; 1A7K } \\
\text { [120]; 1GYQ [121] }\end{array}$ & $\begin{array}{l}\text { 1YWG [122]; 2B4R, } \\
\text { 2B4T [123] }\end{array}$ & 2X0N [124]; 4P8R [125] & $\begin{array}{l}\text { 1K3T [126]; 1ML3 [127]; } \\
\text { 1QXS [128]; 3IDS [129] }\end{array}$ \\
\hline $\begin{array}{l}\text { Glycerol-3-phosphate } \\
\text { dehydrogenase (GPDH) }\end{array}$ & & & & $\begin{array}{l}\text { 1EVY, 1EVZ } \\
\text { [130];1JDJ, 1M66, } \\
\text { 1M67, 1N1G [131]; } \\
\text { 1N1E [132] }\end{array}$ & & & \\
\hline Glyoxalase I (GLO1) & & & $2 \mathrm{C} 21[133]$ & & & & \\
\hline Glyoxalase II (GLO2) & & 2P18, 2P1E [134] & & & & & \\
\hline GMP synthetase (GMPS) & & & & & 3UOW [135] & & \\
\hline Guanylate kinase (GK) & & & & & 1Z6G [136] & & \\
\hline Heat shock protein 90 (HSP90) & & & $\begin{array}{l}\text { 3H80 [137], 3Q5J, } \\
\text { 3Q5K, 3Q5L, [138]; } \\
\text { 3U67 [139] }\end{array}$ & & & & \\
\hline
\end{tabular}


Table 1. Cont.

\begin{tabular}{|c|c|c|c|c|c|c|c|}
\hline \multirow{2}{*}{ Protein Target } & \multicolumn{7}{|c|}{ PDB Protein Structure } \\
\hline & L. donovani & L. infantum & L. major & L. mexicana & P. falciparum & T. brucei & T. cruzi \\
\hline $\begin{array}{l}\text { Histidyl-tRNA synthetase } \\
\text { (HisRS) }\end{array}$ & & & & & & 3HRI [140] & 3HRK, 3LC0 [140] \\
\hline Histo-aspartic protease (HAP) & & & & & 3FNS, 3FNT, 3FNU [141] & & \\
\hline $\begin{array}{l}\beta \text {-Hydroxyacyl-acyl carrier } \\
\text { protein Dehydratase (FabZ) }\end{array}$ & & & & & $\begin{array}{l}\text { 3AZ8, 3AZ9, 3AZA, } \\
\text { 3AZB [142] }\end{array}$ & & \\
\hline $\begin{array}{l}\text { (E)-4-hydroxy-3-methyl-but- } \\
\text { 2-enyl-diphosphate reductase } \\
\text { (LytB) }\end{array}$ & & & & & 4N7B [143] & & \\
\hline $\begin{array}{l}\text { Hypoxanthine-guanine } \\
\text { phosphoribosyl transferase } \\
\text { (HGPRT) }\end{array}$ & & & & & 1CJB [144] & & $\begin{array}{l}\text { 1TC1, 1TC2 [145]; } \\
\text { 1P19 [146] }\end{array}$ \\
\hline Lactate dehydrogenase (LDH) & & & & & $\begin{array}{l}\text { 1LDG [147]; 1CEQ, 1CET } \\
\text { [148]; 1T24, 1T25, 1T26, } \\
\text { 1T2C, 1T2D [149]; 1U4O, } \\
\text { 1U4S, 1U5A, 1U5C, 1XIV } \\
\text { [150]; 2A94 [151]; } \\
\text { 4B7U [152] }\end{array}$ & & \\
\hline $\begin{array}{l}\text { Lipoamide dehydrogenase } \\
\text { (LADH) }\end{array}$ & & & & & & & 2QAE [153] \\
\hline Lysyl-tRNA synthetase (Lys-RS) & & & & & $4 \mathrm{H} 02$ [154] & & \\
\hline M1 amino peptidase (A-M1) & & & & & $\begin{array}{l}\text { 4K5L, 4K5M, 4K5N, 4K5O, } \\
4 \mathrm{~K} 5 \mathrm{P}[155]\end{array}$ & & \\
\hline M17 amino peptidase (A-M17) & & & & & $\begin{array}{l}\text { 4K3N [155]; 3KQX, 3KQZ, } \\
\text { 3KR4, 3KR5 [156]; 3T8V, } \\
\text { 3T8W [157] }\end{array}$ & & \\
\hline $\begin{array}{l}\text { M18 aspartyl aminopeptidase } \\
\text { (M18AAP) }\end{array}$ & & & & & 4EME [158] & & \\
\hline $\begin{array}{l}\text { Macrophage infectivity } \\
\text { potentiator (MIP) }\end{array}$ & & & & & & & 1JVW [159] \\
\hline Metacaspase-2 (MCA2) & & & & & & 4AF8, 4AFP, 4AFV [160] & \\
\hline $\begin{array}{l}\text { Metallocarboxypeptidase } 1 \\
\text { (MCP-1) }\end{array}$ & & & & & & & 3DWC [161] \\
\hline $\begin{array}{l}\text { Methionine aminopeptidase } 1 \mathrm{~b} \\
\text { (MAP1b) }\end{array}$ & & & & & 3S6B [162] & & \\
\hline
\end{tabular}


Table 1. Cont

\begin{tabular}{|c|c|c|c|c|c|c|c|}
\hline \multirow{2}{*}{ Protein Target } & \multicolumn{7}{|c|}{ PDB Protein Structure } \\
\hline & L. donovani & L. infantum & L. major & L. mexicana & P. falciparum & T. brucei & T. cruzi \\
\hline $\begin{array}{l}\text { Methionyl-tRNA synthetase } \\
\text { (MetRS) }\end{array}$ & & & 3KFL [163] & & & $\begin{array}{l}\text { 4EG1, 4EG3, 4EG4, 4EG5, } \\
\text { 4EG6, 4EG7, 4EG8, 4EGA } \\
\text { [164]; 4MVW, 2MVX, 4MVY, } \\
\text { 4MW0, 2MW1, 4MW2, } \\
\text { 4MW4, 4MW5, 4MW6, } \\
\text { 4MW7, 4MW9, 4MWB, } \\
\text { 4MWC, 4MWD, } \\
\text { 4MWE [165] }\end{array}$ & \\
\hline $\begin{array}{l}\text { Mitogen-activated protein kinase } \\
\text { (MAPK) }\end{array}$ & & & 3PGI, 3UIB [166] & & & & \\
\hline $\begin{array}{l}N^{5}, N^{10} \text {-Methylenetetrahydrofolate } \\
\text { dehydrogenase/cyclohydrolase } \\
\text { (DHCH) }\end{array}$ & & & $4 \mathrm{~A} 26$ [167] & & & & \\
\hline Nicotinamidase (PnC1) & & 3R2J [168] & & & & & \\
\hline$N$-Myristoyl transferase (NMT) & 2WUU [169] & & $\begin{array}{l}\text { 3H5Z, 2WSA [170]; } \\
\text { 4A2Z, 4A30, 4A31, } \\
\text { 4A32, 4A33 [171] }\end{array}$ & & & & \\
\hline $\begin{array}{l}\text { Nucleoside } \\
\text { 2-deoxyribosyltransferase } \\
\text { (NDRT) }\end{array}$ & & & & & & $\begin{array}{l}\text { 2A0K, 2F2T, 2F62, 2F64, } \\
\text { 2F67 [172] }\end{array}$ & \\
\hline $\begin{array}{l}\text { Nucleoside diphosphate kinase B } \\
\text { (NDKB) }\end{array}$ & & & $\begin{array}{l}\text { 3NGR, 3NGS, } \\
\text { 3NGT, 3NGU [173] }\end{array}$ & & & $\begin{array}{l}\text { 4FKX, 4FKY [174]; 4F4A, } \\
\text { 4F36 [175] }\end{array}$ & $\begin{array}{l}\text { 3NGR, 3NGS, NGT, 3NGU, } \\
\text { 3PRV [173] }\end{array}$ \\
\hline Nucleoside hydrolase (NH) & & & 1EZR [176] & & & & \\
\hline $\begin{array}{l}\text { Inosine-Adenosine-Guanosine } \\
\text { nucleoside hydrolase (IAGNH) }\end{array}$ & & & & & & $\begin{array}{l}\text { 4I70, 4I71, 4I72, 4I73, 4I74, } \\
4 \mathrm{II}[177]\end{array}$ & \\
\hline $\begin{array}{l}\text { Inosine-Guanosine nucleoside } \\
\text { hydrolase (IG-NH) }\end{array}$ & & & & & & $\begin{array}{l}\text { 3FZ0, 4I70, 4I71, 4I72, 4I73, } \\
4 \mathrm{II} 74,4 \mathrm{I} 75[178]\end{array}$ & \\
\hline $\begin{array}{l}\text { Nucleosome assembly } \\
\text { protein (NapL) }\end{array}$ & & & & & $\begin{array}{l}\text { 3FS3 [179]; 3GYV, } \\
\text { 3GYW [180] }\end{array}$ & & \\
\hline Old yellow enzyme (OYE) & & & & & & & $\begin{array}{l}\text { 3ATY, 3ATZ [181]; 4E2B, } \\
\text { 4E2D [182] }\end{array}$ \\
\hline Oligopeptidase B (OPB) & & & 2XE4 [183] & & & 4BP8, 4BP9 [184] & \\
\hline Ornithine decarboxylase (ODC) & & & & & & $\begin{array}{l}\text { 1QU4 [185]; 1F3T [186]; } \\
\text { 1NJJ [187] }\end{array}$ & \\
\hline
\end{tabular}


Table 1. Cont

\begin{tabular}{|c|c|c|c|c|c|c|c|}
\hline \multirow{2}{*}{ Protein Target } & \multicolumn{7}{|c|}{ PDB Protein Structure } \\
\hline & L. donovani & L. infantum & L. major & L. mexicana & P. falciparum & T. brucei & T. cruzi \\
\hline $\begin{array}{l}\text { Ornithine } \delta \text {-aminotransferase } \\
\text { (OAT) }\end{array}$ & & & & & 3NTJ, 3LG0 [188] & & \\
\hline $\begin{array}{l}\text { Orotidine } 5^{\prime} \text {-monophophate } \\
\text { decarboxylase (OMPDC) }\end{array}$ & & 3QW3 [189] & & & $\begin{array}{l}\text { 2QAF, 2Q8Z, 3BAR [190]; } \\
\text { 2ZCG [191]; 2ZA1, 2ZA2, } \\
\text { 2ZA3 [192]; 3S9Y [193]; } \\
\text { 3VI2 [194]; 2Q8L [195]; 2F84 } \\
\text { [196]; 3MWA, 3N2M, 3N34, } \\
\text { 3N3M [197]; }\end{array}$ & & \\
\hline $\begin{array}{l}\text { Oxoacyl acyl-carrier-protein } \\
\text { reductase (OAR) }\end{array}$ & & & & & 2C07 [198] & & \\
\hline Peptide deformylase (PDF) & & & & & $\begin{array}{l}\text { 1JYM [199]; 1RL4, } \\
\text { 1RQC [200] }\end{array}$ & & \\
\hline $\begin{array}{l}\text { Peroxisomal targeting } \\
\text { signal } 1 \text { (PTS1) }\end{array}$ & & & & & & $\begin{array}{l}\text { 3CV0, 3CVL, CVN, 3CVP, } \\
\text { 3CVQ [201] }\end{array}$ & \\
\hline $\begin{array}{l}\text { Peroxisomal targeting } \\
\text { signal } 2 \text { (PTS2) }\end{array}$ & & & & & & 2F2J [110] & \\
\hline $\begin{array}{l}\text { Phosphethanolamine } \\
\text { methyltransferase (PMT) }\end{array}$ & & & & & $\begin{array}{l}\text { 3UJ6, 3UJ7, 3UJ8, 3UJ9, } \\
\text { 3UJA, 3UJB [202] }\end{array}$ & & \\
\hline Phosphodiesterase B1 (PDEB1) & & & 2R8Q [203] & & & $4 \mathrm{I} 15$ [204] & \\
\hline Phosphodiesterase C (PDEC) & & & & & & & 3V93 [205]; 3V94 [206] \\
\hline $\begin{array}{l}\text { Phosphoenolpyruvate } \\
\text { carboxykinase (PEPCH) }\end{array}$ & & & & & & & 1II2 [207] \\
\hline Phosphofructokinase (PFK) & & & & & & 3F5M [208] & \\
\hline 6-Phosphoglucolactonase (6PGL) & & & & & & 2J0E [209]; 3E7F, 3EB9 [210] & \\
\hline $\begin{array}{l}\text { 6-Phosphogluconate } \\
\text { dehydrogenase (6PGDH) }\end{array}$ & & & & & & 1PGJ [211] & \\
\hline Phosphoglucose isomerase (PGI) & & & & 1Q50, 1T10 [212] & & $2 \mathrm{O} 2 \mathrm{C}, 2 \mathrm{O} 2 \mathrm{D}[213]$ & \\
\hline Phosphoglycerate kinase (PGK) & & & & & 3OZA, 3OZ7 [214] & 13PK [215]; 16PK [216] & \\
\hline $\begin{array}{l}\text { Phosphoglycerate mutase } \\
\text { (PGAM) }\end{array}$ & & & & 3IGY, 3IGZ [217] & $3 \mathrm{EOZ}[218]$ & 3NVL [219] & \\
\hline
\end{tabular}


Table 1. Cont.

\begin{tabular}{|c|c|c|c|c|c|c|c|}
\hline \multirow{2}{*}{ Protein Target } & \multicolumn{7}{|c|}{ PDB Protein Structure } \\
\hline & L. donovani & L. infantum & L. major & L. mexicana & P. falciparum & T. brucei & T. cruzi \\
\hline Phosphomannomutase (PMM) & & & & 2I54, 2I55 [220] & & 3F9R [221] & \\
\hline Plasmepsin I (PMI) & & & & & $\begin{array}{l}\text { 2R9B [222]; 3QRV, 3QS1 } \\
\text { [223]; }\end{array}$ & & \\
\hline Plasmepsin II (PMII) & & & & & $\begin{array}{l}\text { 1SME [224]; 1LEE, 1LF2 } \\
\text { [225]; 1LF3, 1LF4 [226]; } \\
\text { 2BJU [227]; 2IGX, 2IGY } \\
\text { [228]; 3F9Q [229]; 1M43 } \\
\text { [230]; 1ME6 [231]; 1W6H, } \\
\text { 1W6I [232]; 1XDH, 1XE5, } \\
\text { 1XE6 [233] }\end{array}$ & & \\
\hline Plasmepsin IV (PMIV) & & & & & 1LS5 [225] & & \\
\hline Proline racemase (PRACA) & & & & & & & 1W61, 1W62 [234] \\
\hline Protein Kinase 5 (PK5) & & & & & 1OB3, 1V0O, 1V0P [235] & & \\
\hline $\begin{array}{l}\text { Protein tyrosine } \\
\text { phosphatase } 1 \text { (PTP1) }\end{array}$ & & & & & & $3 \mathrm{M} 4 \mathrm{U}[236]$ & $4 \mathrm{AZ1}[237]$ \\
\hline Pteridine reductase 1 (PTR1) & $2 \mathrm{XOX}[238]$ & & $\begin{array}{l}\text { 1E7W, 1E92 [239]; } \\
\text { 1WOC [240]; 2BF7, } \\
\text { 2BFA,2BFM, 2BFO, } \\
\text { 2BFP [241]; 2QHX, } \\
\text { 3H4V [242] }\end{array}$ & & & $\begin{array}{l}\text { 2C7V [243]; 2WD7, 2WD8, } \\
\text { 3GN1, 3GN2 [244]; 2VZ0 } \\
\text { [245]; 3BMC, 3BMN, 3BMO, } \\
\text { 3BMQ, 3JQ6, 3JQ7, 3JQ8, } \\
\text { 3JQ9, 3JQA, 3JQB, 3JQC, } \\
\text { 3JQD, 3JQE, 3JQF, 3JQG } \\
\text { [246]; 2X9N, 2X9G, 2X9V, } \\
\text { 3MCV [247]; 2YHI [248] }\end{array}$ & \\
\hline Pteridine reductase 2 (PTR2) & & & & & & & 1MXF, 1MXH [249] \\
\hline $\begin{array}{l}\text { Purine nucleoside } \\
\text { phosphorylase (PNP) }\end{array}$ & & & & & $\begin{array}{l}\text { 1NW4, 1Q1G [250]; 2BSX, } \\
\text { 1SQ6 [251]; 3ENZ [252] }\end{array}$ & & \\
\hline Pyridoxal kinase (PdxK) & & & & & & 3ZS7 [253] & \\
\hline Pyruvate kinase (PYK) & & & & $\begin{array}{l}\text { 1PKL [254]; 3E0V, } \\
\text { 3E0W [255]; 3IS4, } \\
\text { 3KTX [256]; } \\
\text { 3HQN, 3HQO, } \\
\text { 3HQP, 3HQQ } \\
\text { [257]; 3PP7, 3QV6, } \\
\text { 3QV7, 3QV8, } \\
\text { 3QV9 [258]; } \\
\text { 3SRK [259] }\end{array}$ & $3 \mathrm{KHD}[260]$ & $\begin{array}{l}\text { 4HYV, 4HYW [261]; 4KCT, } \\
4 \mathrm{KCU}, 4 \mathrm{KCV}, 4 \mathrm{KCW} \text { [262] }\end{array}$ & $\begin{array}{l}\text { 3PP7, 3QV6, 3QV7, 3QV8, } \\
\text { 3QV9 [258] }\end{array}$ \\
\hline
\end{tabular}


Table 1. Cont

\begin{tabular}{|c|c|c|c|c|c|c|c|}
\hline \multirow{2}{*}{ Protein Target } & \multicolumn{7}{|c|}{ PDB Protein Structure } \\
\hline & L. donovani & L. infantum & L. major & L. mexicana & P. falciparum & T. brucei & T. cruzi \\
\hline Rhodesain & & & & & & 2P7U [38], 2P86 [263] & \\
\hline $\begin{array}{l}\text { Ribose 5-phosphate isomerase } \\
\text { type B (RPIB) }\end{array}$ & & & & & & & $\begin{array}{l}\text { 3K7O, 3K7S, 3K8C, } \\
\text { 3M1P [264] }\end{array}$ \\
\hline $\begin{array}{l}\text { Ribulose 5-phosphate } \\
\text { 3-epimerase (a1RPE) }\end{array}$ & & & & & 1TQX [265] & & \\
\hline RNA Editing ligase 1 (REL1) & & & & & & $1 \mathrm{XDN}[266]$ & \\
\hline $\begin{array}{l}\text { S-Adenosylhomocysteine } \\
\text { hydrolase (SAHH) }\end{array}$ & & & 3G1U [267] & & 1V8B [268] & 3H9U [269] & \\
\hline Seryl-tRNA synthetase (SerRS) & & & & & & 3LSQ, 3LSS [270] & \\
\hline Sirtuin 2A (Sir2A) & & & & & 3U31, 3U3D [271] & & \\
\hline Spermidine synthase (SpdSyn) & & & & & $\begin{array}{l}\text { 2HTE [136] ; 2I7C, 2PSS, } \\
\text { 2PT6, 2PT9 [272]; 3B7P; } \\
\text { 2PWP [273]; 3RIE [274] }\end{array}$ & & 3BWC [275] \\
\hline Sterol 14- $\alpha$ Demethylase (CYP51) & & 3L4D [276] & & & & $\begin{array}{l}\text { 3G1Q, 3GW9 [277]; 2WV2, } \\
\text { 2X2N [278]; 3P99 [279]; } \\
\text { 3TIK [280]; 4BJK [281]; } \\
\text { 4G7G, 4G3J [282]; }\end{array}$ & $\begin{array}{l}\text { 2WUZ, 2WX2 [278]; 3K1O, } \\
\text { 3KHM, 3KSW [283]; 4H6O } \\
\text { [284]; 3ZG2, 3ZG3 [285]; } \\
\text { 4COH [286]; 4BY0 [287]; } \\
\text { 4BMM [288] }\end{array}$ \\
\hline $\begin{array}{l}\text { Sterol carrier protein, type } 2 \\
\text { thiolase (SCP2-thiolase) }\end{array}$ & & & & 3ZBG, 4B19 [289] & & 4BI9 [289] & \\
\hline Superoxide dismutase (SOD) & & & & & 2BPI [290] & 3ESF [291] & 2GPC [291] \\
\hline $\begin{array}{l}\text { Terminal RNA uridyltransferase } \\
\text { (TUTase) }\end{array}$ & & & & & & $\begin{array}{l}\text { 2B4V, 2B51, 2B56 [292]; 2IKF, } \\
\text { 2NOM [293]; 2Q0C, 2Q0D, } \\
\text { 2Q0E, 2Q0F, 2Q0G [294] }\end{array}$ & \\
\hline $\begin{array}{l}\text { Thiamine phosphate } \\
\text { synthase (TPS) }\end{array}$ & & & & & & $2 Y 6 Z$ [295] & \\
\hline $\begin{array}{l}\text { Thiol-dependent } \\
\text { reductase } 1 \text { (TDR1) }\end{array}$ & & 4AGS [296] & & & & & \\
\hline Thioredoxin reductase (TrxR) & & & & & 4J56, 4J57 [297] & & \\
\hline Thymidylate kinase (TMPK) & & & & & $\begin{array}{l}\text { 2WWF, 2WWG, 2WWH, } \\
\text { 2WWI [298]; 2YOF, 2YOG, } \\
\text { 2YOH [299] }\end{array}$ & & \\
\hline
\end{tabular}


Table 1. Cont.

\begin{tabular}{|c|c|c|c|c|c|c|c|}
\hline \multirow{2}{*}{ Protein Target } & \multicolumn{7}{|c|}{ PDB Protein Structure } \\
\hline & L. donovani & L. infantum & L. major & L. mexicana & P. falciparum & T. brucei & T. cruzi \\
\hline Transkelolase (Tk) & & & & 1R9J [300] & & & \\
\hline $\begin{array}{l}\text { Translationally controlled tumor } \\
\text { protein (TCTP) }\end{array}$ & & & & & 3Р3К [301] & & \\
\hline trans-Sialidase (TS) & & & & & & & $\begin{array}{l}\text { 1MS0, 1MS1, 1MS3, 1MS4, } \\
\text { 1MS5, 1MS8, 1MS9, 1MR5 } \\
\text { [302]; 1S0I, 1S0J, 2AH2 } \\
\text { [303]; 3B69 [304]; } \\
\text { 3OPZ [305] }\end{array}$ \\
\hline Triosephosphate isomerase (TIM) & & & & $\begin{array}{l}\text { 1AMK [306]; 1IF2; } \\
\text { [307]; 1N55 [308]; } \\
\text { 2VXN [309]; 2Y61, } \\
\text { 2Y62, 2Y63 [310] }\end{array}$ & $\begin{array}{l}\text { 1YDV [311]; 1LYX, 1LZO } \\
\text { [312]; 1M7O, 1M7P [313]; } \\
\text { 1O5X [314]; 2VFI [315] }\end{array}$ & $\begin{array}{l}\text { 1AG1 [316]; 3TIM [317]; } \\
\text { 1IIG, 1IIH; 6TIM [318]; } \\
\text { 5TIM [319]; 4TIM [320]; } \\
\text { 1TPD, 1TRD, 2V5L [321]; } \\
\text { 1TPE, 1TPF [322]; 1ML1 } \\
\text { [323]; 1DKW [324]; 2J24, } \\
\text { 2J27 [325]; 2X1U [326] }\end{array}$ & $\begin{array}{l}\text { 1TCD [327]; 1CI1 [328]; } \\
\text { 1SUX [329]; 2OMA [330]; } \\
\text { 2V5B [331]; 3Q37 [332]; } \\
\text { 4JEQ [333] }\end{array}$ \\
\hline Trypanothione reductase (TR) & & $\begin{array}{l}\text { 2JK6, 2W0H [334]; } \\
\text { 2X50 [335]; 2YAU } \\
\text { [336]; 4ADW, } \\
\text { 4APN [337] }\end{array}$ & & & & $\begin{array}{l}\text { 2WBA [338]; 2WOI, 2WOV, } \\
\text { 2WOW, 2WP5, 2WP6, 2 } \\
\text { WPC, 2WPE, 2 WPF [339]; } \\
\text { 4NEV [340]; }\end{array}$ & $\begin{array}{l}\text { 1NDA [341]; 1AOG [342]; } \\
\text { 1BZL [343]; 1GXF [344]; } \\
\text { 4NEW [340] }\end{array}$ \\
\hline $\begin{array}{l}\text { Tryparedoxin-dependent } \\
\text { peroxidase (TDPX) }\end{array}$ & & & & & & 2VUP [345] & 4LLR [346] \\
\hline $\begin{array}{l}\text { Tryptophanyl-tRNA synthetase } \\
\text { (TrpRS) }\end{array}$ & & & & & $4 J 75,4 J 76[347]$ & $3 \mathrm{I} 05[348]$ & \\
\hline Tyrosyl-tRNA synthase (TyrRS) & & & $\begin{array}{l}\text { 3P0H, 3P0I, 3Р0J } \\
{[349]}\end{array}$ & & 3VGJ [350] & & \\
\hline $\begin{array}{l}\text { Ubiquitin and Nedd8 } \\
\text { Hydrolase (UCHL3) }\end{array}$ & & & & & 2WDT, 2WE6 [351] & & \\
\hline $\begin{array}{l}\text { UDP-Galactose } \\
4^{\prime} \text {-epimerase (UGE) }\end{array}$ & & & & & & 1GY8 [352] & \\
\hline $\begin{array}{l}\text { UDP-Galactopyranose } \\
\text { mutase (UGM) }\end{array}$ & & & & & & & 4DSG, 4DSH [353] \\
\hline $\begin{array}{l}\text { UDP-glucose } \\
\text { pyrophosphorylase (UGP) }\end{array}$ & & & $\begin{array}{l}\text { 4M28, 4M2A, } \\
\text { 2OEF, 2OEG [354] }\end{array}$ & & & & \\
\hline $\begin{array}{l}\text { UDP-N-acetylglucosamine } \\
\text { pyrophosphorylase (UAP) }\end{array}$ & & & & & & 4BQH [355] & \\
\hline UMP synthase (UMPS) & 3QW4 [189] & & & & & & \\
\hline Uridine phophorylase (UP) & & & & & & 3BJE [356] & \\
\hline
\end{tabular}




\section{Parasite Molecular Targets}

Numerous protozoal proteins have been identified as druggable or potentially drugable targets, including deoxyuridine triphosphate nucleotidohydrolase, dihydroorotate dehydrogenase, farnesyl diphosphate synthase, glyceraldehyde 3-phosphate dehydrogenase, nucleoside diphosphate kinase B, pteridine reductase, pyruvate kinase, sterol $14 \alpha$-demethylase, triosephosphate isomerase, and trypanothione reductase [10], and many of these have been characterized crystallographically (see Table 1). These protein crystal structures serve as-structural models for in-silico screening using molecular docking techniques. Often, there are different structures, usually with different co-crystallized ligands, that can provide slightly different and complementary binding sites for docking studies.

\section{Molecular Docking Studies}

Molecular docking has become one of the most important modeling tools in modern drug discovery. It is a very convenient and cheap means to study protein-ligand interactions. It can be used to rank compounds for prioritization in lead discovery and development. It can also be used to identify potential inhibitors, substrates, activators or binding partners from compound libraries that contains few hundreds to millions of compounds. Several recent reviews on molecular docking have appeared [357-360], so molecular docking principles and approaches will not be covered here.

Molecular docking has become a well-accepted complement to X-ray crystallography and NMR spectroscopy in studying drug-drug target interactions. It also gives the medicinal chemist a means to access certain ligand binding poses that even X-ray crystallography and NMR spectroscopy may not inform the most experienced structural biologist thereby aiding the medicinal chemist in the creative enterprise of structure-based drug design. In some cases, it has become a replacement or a complement to high throughput compound screening.

Despite current and potential applications, as well as the successes of molecular docking in drug discovery, there remain limitations and caveat in the interpretation of results from molecular docking studies. These limitations stem, mostly, from the inability of the scoring functions in molecular docking algorithms to account for local and global macromolecular dynamics, in addition to inability to accurately predict covalent interactions and solvent accessibilities: (1) in most cases the protein is modeled as a rigid structure without flexibility; (2) solvation of the active/binding site and of the ligand is usually excluded; (3) free-energy estimation of protein-ligand complexes is largely ignored [357,361,362]. Molecular docking methodology, cavity definition and search algorithms, and thermodynamic scoring functions continue to improve, however [363].

Molecular docking has increasing found use in drug discovery programs focused on tropical diseases. The applications include target-based screening of natural products libraries or databases [364,365]. Popular natural product databases include the Dictionary of Natural Products [366], Napralert [367], and the ZINC natural products database [368].

Table 2 lists popular molecular docking software recently used for virtual screening of natural product libraries. The list is not meant as an endorsement, but does reflect the current availability of molecular docking software. In addition, several other commercial and freeware molecular docking packages are available. There are, however, additional effects to be considered in docking studies with natural products: (1) many natural products may have poor bioavailability due to limited solubility, membrane permeability, hydrolysis, or other metabolic transformations; (2) the ligands may also target homologous isozymes in humans and cause serious side effects; (3) the docking studies do not account for possible synergism with the bioactive antiparasitic compounds.

In spite of the above limitations, molecular docking studies of phytochemical ligands with identified protein targets provide the possibilities to identify natural compounds that may themselves function as efficacious drugs, may serve as lead structures for chemical modification and optimization, or provide structural templates for de novo drug synthesis. 
Table 2. Popular molecular docking programs used for virtual screening of natural product libraries.

\begin{tabular}{ll}
\hline Docking Program & Source \\
\hline AutoDock & Scripps Research Institute, http://autodock.scripps.edu/ [369] \\
\hline Molegro Virtual Docker & Molegr ApS (no longer available) [370] \\
\hline GLIDE & Schrödinger, https://www.schrodinger.com/Glide/ [371] \\
\hline AutoDock Vina & Scripps Research Institute, http://vina.scripps.edu/ [372] \\
\hline Molecular Operating Environment (MOE) & $\begin{array}{l}\text { Chemical Computing Group, http://www.chemcomp.com/MOE- } \\
\text { Molecular_Operating_Environment.htm }\end{array}$ \\
\hline CDOCKER (Discovery Studio) & $\begin{array}{l}\text { Dassault Systèmes BIOVIA, http://accelrys.com/products/ } \\
\text { collaborative-science/biovia-discovery-studio/ }\end{array}$ \\
\hline ArgusLab & http://www.arguslab.com/arguslab.com/ArgusLab.html \\
\hline iGemDock & $\begin{array}{l}\text { National Chiao Tung University, } \\
\text { http://gemdock.life.nctu.edu.tw/dock/download.php }\end{array}$ \\
\hline Surflex-Dock & Certara USA, Inc., https://www.certara.com/ [373] \\
\hline GOLD & $\begin{array}{l}\text { Cambridge Crystallographic Data Centre (CCDC), http: } \\
\text { //www.ccdc.cam.ac.uk/solutions/csd-discovery/components/gold/ }\end{array}$ \\
\hline FlexX & BioSolveIT, http://www.biosolveit.de/FlexX/ \\
\hline
\end{tabular}

Some published reports have focused on natural products that are biologically active against one or more protozoan organism or any of their validated drug targets [374-378] while other works have focused on natural products or phytochemicals that were isolated from plants with historical ethnomedicinal therapeutic use [379,380]. Molecular docking has been used to identify, in silico, the selectivity of some compounds or classes of compounds for specific protozoan drug targets. In the reports by us about the selectivity of antiparasitic isoprenoid derivatives for drug targets from Leishmania spp., for example, antiparasitic monoterpenoids were found to selectively dock to L. infantum nicotinamidase, L. major uridine diphosphate-glucose pyrophosphorylase, and methionyl $\mathrm{t}$-RNA synthetase, while germacranolide sesquiterpenoids were selective for L. major methionyl t-RNA synthetase, and dihydroorotate dehydrogenase [375]. It was also shown in that work that diterpenoids generally favored docking to L. mexicana glycerol-3-phosphate dehydrogenase. In addition, the tetranortriterpene limonoids showed some selectivity for L. mexicana glycerol-3-phosphate dehydrogenase and L. major dihydroorotate dehydrogenase while withanolides docked more selectively with $L$. major uridine diphosphate-glucose pyrophosphorylase.

Also, although not surprising, were the strong docking preference of several steroids and triterpenoids for L. infantum sterol $14 \alpha$-demethylase (LinfCYP51). Of particular note is the strong docking preference of the hydroperoxy sterol 24-hydroperoxy-24, 25-vinylcholesterol and 24,25-epoxywithanolide D (Figure 1) to LinfCYP51 (Figure 2). In vitro evaluation of these compounds as possible inhibitors of LinfCYP51 remains to be tested, but in vitro antileishmanial screening and in silico docking with LinfCYP51 of oleanolic acid (Figure 1) corroborate these findings [381].

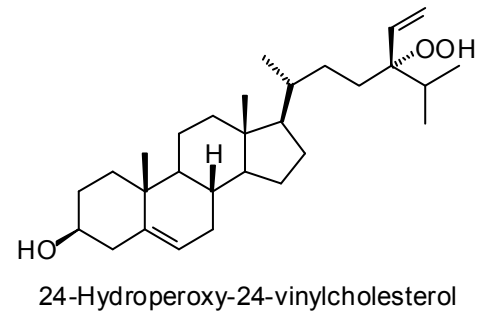

Figure 1. Phytochemical ligands with encouraging docking properties with L. infantum sterol $14 \alpha$-demethylase (LinfCYP51). 


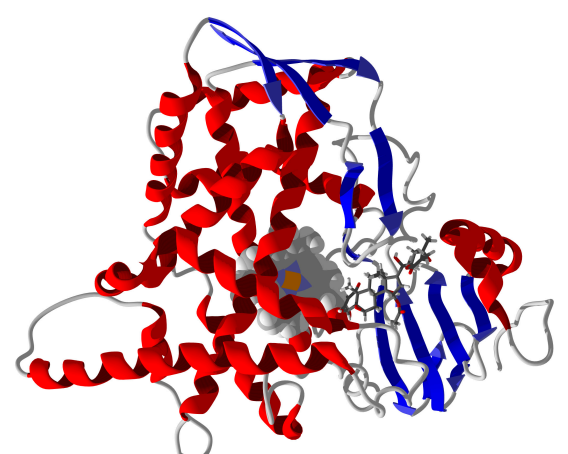

(A)

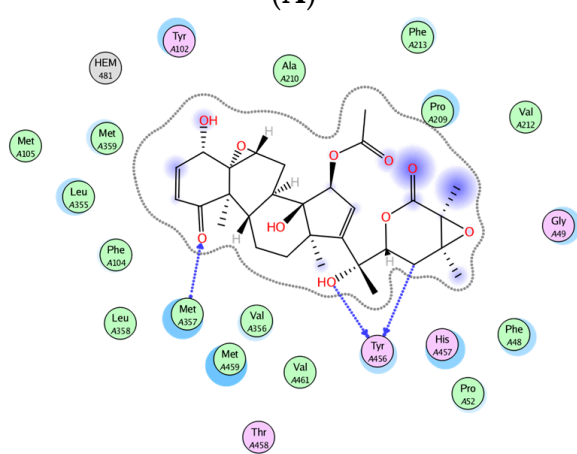

(C)

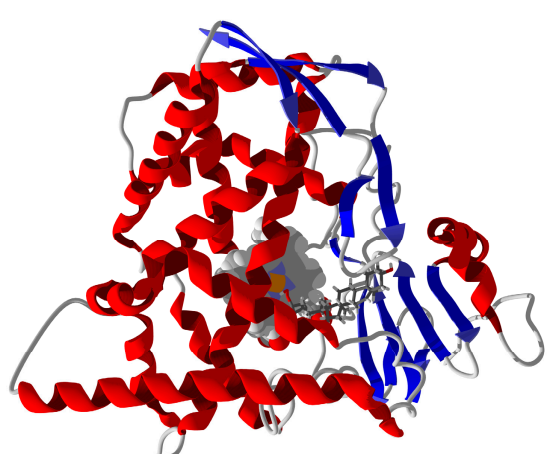

(B)

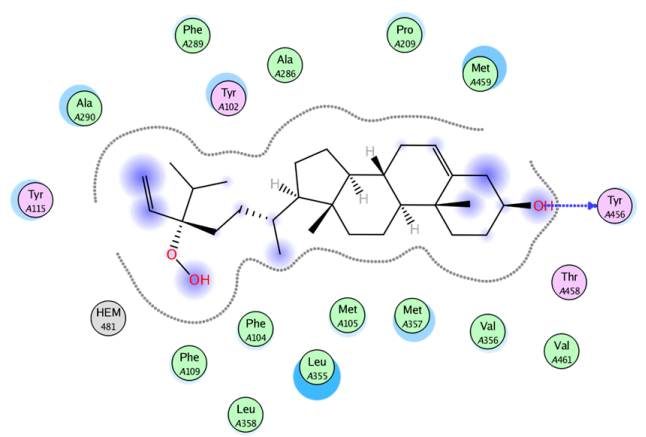

(D)

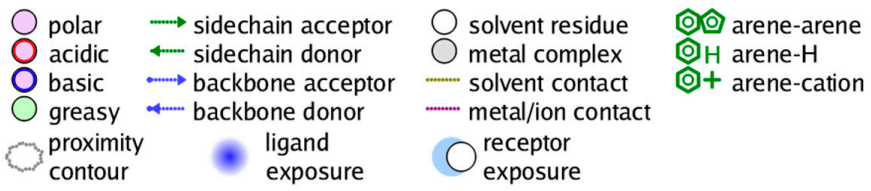

Figure 2. The lowest energy docking poses of L. infantum sterol $14 \alpha$-demethylase (LinfCYP51) with 24,25-epoxywithanolide D (A) and 24-hydroperoxy-24,25-vinylcholesterol (B) (stick figures); The heme cofactor is shown as a space-filling model. LinfCYP51 was predicted to have hydrogen bonding interactions with 24,25-epoxywithanolide D through the backbones of Tyr 458 and Met 357 residues, in addition, to van der Waals interactions with Leu 355, Met 359 and Val 356 (C); In the case of 24-hydroperoxy-24,25-vinylcholesterol, hydrogen bonding with Tyr 456 was predicted as well (D). Extensive van der Waals interactions between the hydroperoxy sterol and Met 357, Met 459 and Phe 104 of LinfCYP51 were also predicted.

\subsection{Leishmania and Trypanosoma Targets}

The flavonoids (+)-catechin and (-)-epicatechin (Figure 3) have been shown to be effective inhibitors of Leishmania amazonensis arginase with $\mathrm{IC}_{50}$ values of 0.77 and $1.8 \mu \mathrm{M}$, respectively [382]. Molecular docking (MolDock) of these compounds has revealed differences in their interactions with the amino acid residues of the active site of arginase. (+)-Catechin docks in the active site with primary hydrogen-bonding interactions to Ala192, Thr257, and Asp141. In contrast, the primary hydrogen-bonding contacts for (-)-epicatechin were with Ser150, His154, Asp245, Asn 152, Thr257, and Asn243.

Venkatesan and co-workers [383] carried out a docking investigation of Leishmania trypanothione synthase with the MS Discovery database of 800 compounds, using AutoDock. The best phytochemicals docking to the crystal structure of $L$. major trypanothione synthase were theaflavin, hecogenin acetate, $\beta$-carotene, glycyrrhetic acid, $18 \alpha$-glycyrrhetic acid, convallatoxin, tubocurarine, and lunarine (Figure 4). Strongly docking phytochemical ligands to a homology-modeled structure of L. donovani trypanothione synthase included 10-hydroxycamptothecin, camptothecin, tubocurarine, tomatine, cafestol, (-)-asarinin, pomiferin, 7-oxocholesterol, mundulone, and dehydrorotenone (Figure 4). 
In a complementary examination of antileishmanial sesquiterpenoids, Bernal and Coy-Barrera found the coumarin-derived sesquiterpenoid kamalone to be a strongly docking ligand for L. major trypanothione synthase [378].<smiles>Oc1cc(O)c2c(c1)OC(c1ccc(O)c(O)c1)C(O)C2</smiles>

$(+)$-Catechin<smiles>Oc1cc(O)c2c(c1)OC(c1ccc(O)c(O)c1)C(O)C2</smiles>

(-)-Epicatechin

Figure 3. Leishmania amazonensis arginase inhibitors.

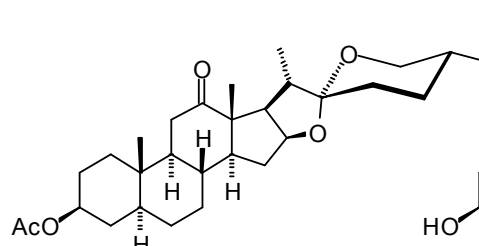

Hecogenin acetate<smiles>C=CC1=C(C)CCCC1(C)C</smiles><smiles>CC(C)(C)O</smiles>
Glycyrrhetic acid<smiles>C/C=C/C=C/C</smiles><smiles>C/C=C\C=C\C=C(C)\C=C\C=C(C)\C=C\C1=C(C)CCCC1(C)C</smiles><smiles>O=c1c(O)cc([C@@H]2Oc3cc(O)cc(O)c3C[C@H]2O)cc2c(C3Oc4cc(O)cc(O)c4CC3O)cc(O)c(O)c12</smiles><smiles>COc1cc2c(cc1O)[C@H](Cc1ccc(Oc3ccc(O)cc3)cc1)N(C)CC2</smiles>
Tubocurarine

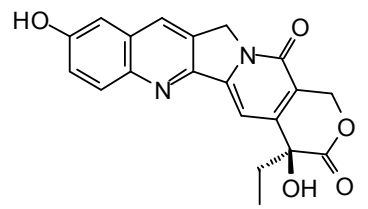
10-Hydroxycamptothecin<smiles>O=C1CC[C@@]2(c3cc4ccc3NCCCCNCCCNC(=O)/C=C/4)OC2C1</smiles>

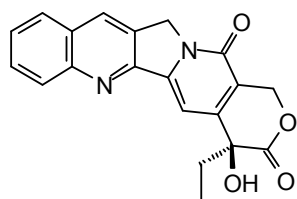
Camptothecin<smiles>C[C@]12CCc3occc3[C@H]1CC[C@@H]1C[C@H]3CC[C@@]12C[C@@]3(O)CO</smiles>

Cafestol 型

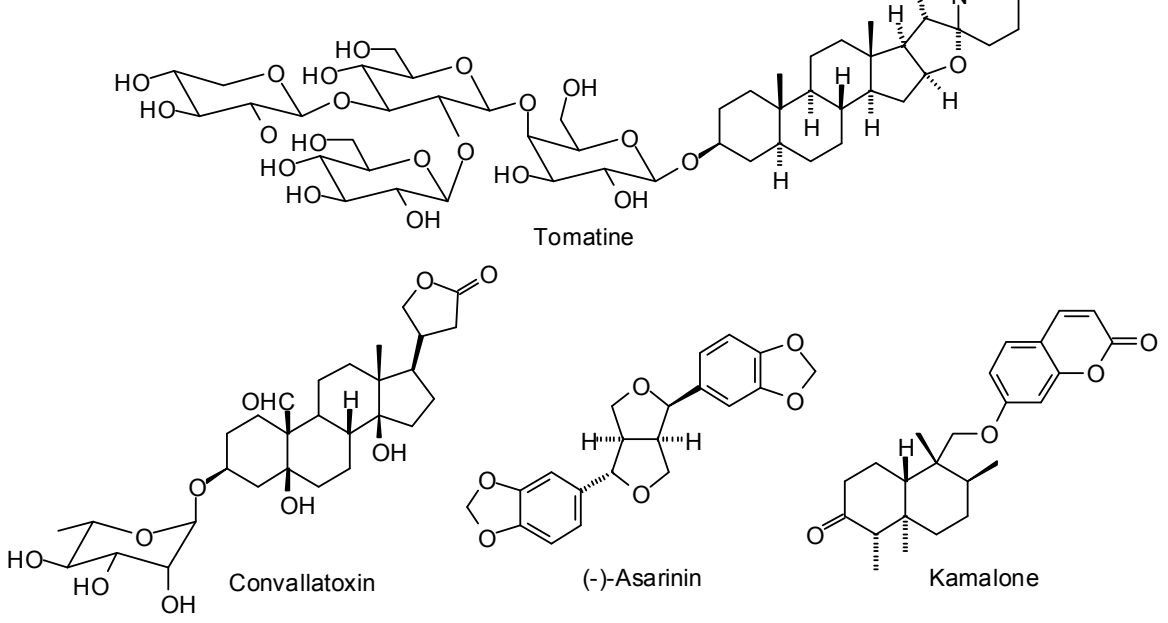

Figure 4. Cont. 


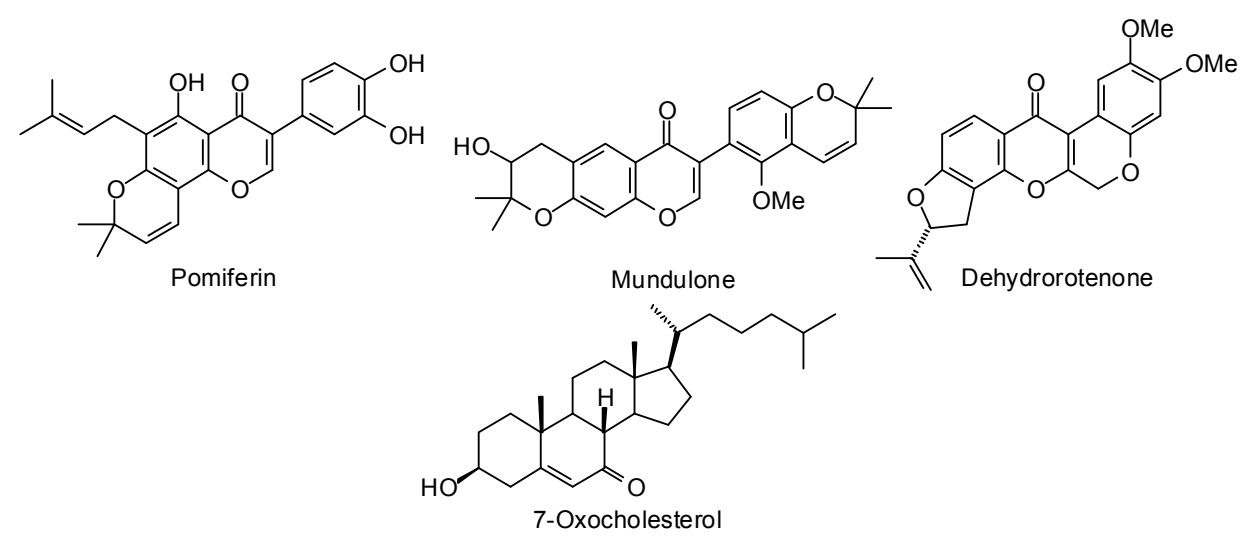

Figure 4. Phytochemical ligands with encouraging docking properties with Leishmania trypanothione synthase.

An in-silico screening study (MolDock) of antiparasitic medicinal plants from West Africa has revealed several phytochemicals with strong, selective docking to a number of Trypanosoma brucei protein targets [379]. This investigation revealed that several triterpenoid and steroid ligands (e.g., grandifoliolenone, lawnermis acid methyl ester, lawsaritol A, wallichianol, 14-hydroxy-isocarpanolide, physagulins J, K, and L, vamonolide, withangulatins E, F, and I, clerosterol, and $\beta$-sitosterol, Figure 5) were selective for T. brucei sterol $14 \alpha$-demethylase.

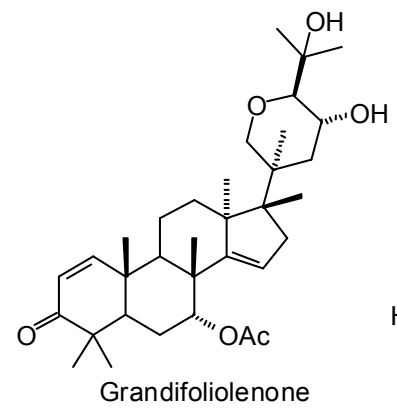

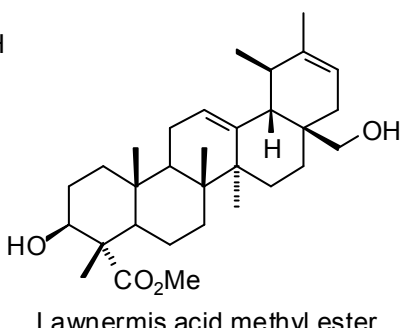<smiles>CC(CO)C1CCC2(C)CCC3(C)C(CCCC4(C)C5CCC(O)C(C)(C)C5CCC34)C12</smiles>

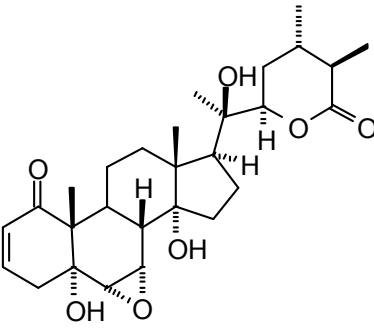

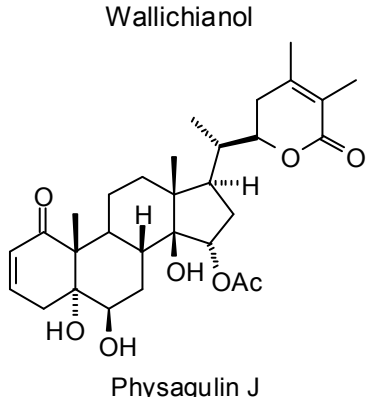

14-Hydroxyisocarpanolide

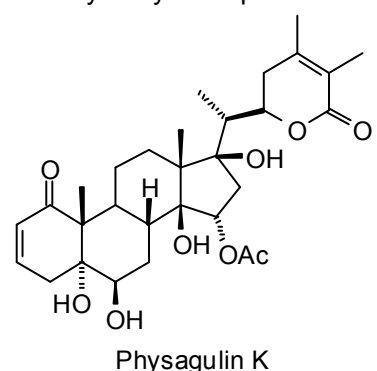<smiles>CC1=C(C)C(=O)OC(C(C)C2(O)C[C@H](O)[C@]3(O)C4CC(O)C5(O)CC=CC(=O)C45CCC23C)C1</smiles>

Figure 5. Cont. 

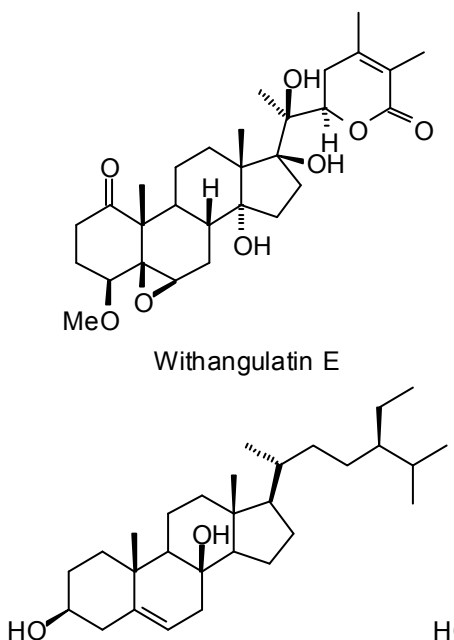

Lawsaritol A

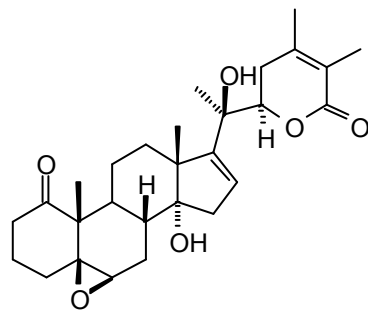

Withangulatin $\mathrm{F}$

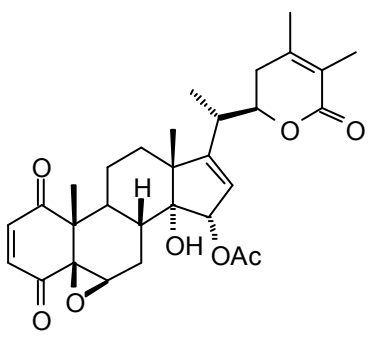

Withangulatin I

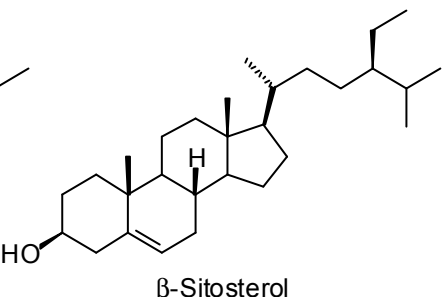

Figure 5. Phytochemical ligands that docked selectively with Trypanosoma brucei $14 \alpha$-demethylase.

Chromenes (e.g., 6-acetyl-2,2-dimethylchroman, $\mathrm{O}$-methylencecalinol, and garcipyran, Figure 6), showed preferential docking to T. brucei triosephosphate isomerase, while indole alkaloids (e.g., reserpine, rescinnamine, methyl reserpate, geissoschizol, and 19,20-dehydroreserpiline, Figure 7) exhibited notably low docking energies for T. brucei UDP-galactose-4'-epimerase.<smiles>CC(=O)c1ccc2c(c1)CCC(C)(C)O2</smiles>

6-Acetyl-2,2-dimethylchroman<smiles>COc1cc2c(cc1C(C)OC)C=CC(C)(C)O2</smiles>

O-Methylencecalinol<smiles>COc1cc(-c2ccc3c(c2)C=CC(C)(CO)O3)cc(O)c1O</smiles>

Garcipyran

Figure 6. Phytochemical ligands that docked selectively with Trypanosoma brucei triosephosphate isomerase.

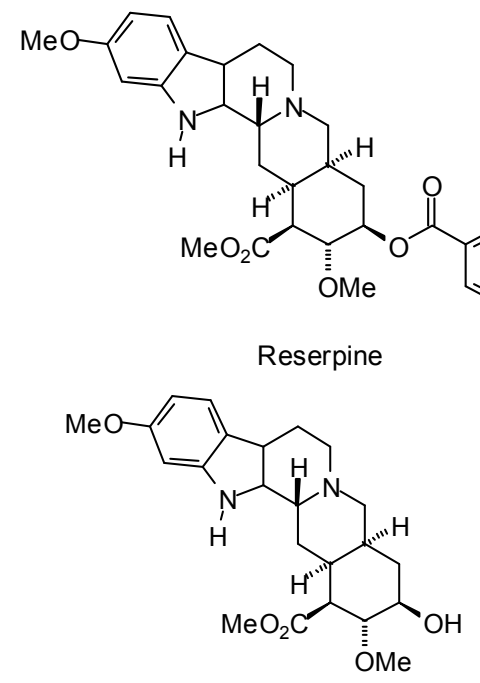

Methyl reserpate<smiles>COC(OC)OC</smiles>

Rescinnamine<smiles>COc1cc2c(cc1OC)C1CCN3CC4=C(C)OC=C(C(C)=O)[C@H]4C[C@@]13C2</smiles>

19,20-Dehydroreserpiline

Figure 7. Phytochemical ligands with encouraging docking properties with Trypanosoma brucei UDP-galactose-4'-epimerase. 
Trypanothione reductase has been investigated as a protein target for several parasitic protozoa, including Leishmania spp., T. brucei, and T. cruzi [384]. The flavonoid taxifolin (Figure 8) was found to dock (AutoDock) at the active site of L. infantum trypanothione reductase [385]. Similarly, Ribeiro and co-workers, using MolDock, found the flavonoid ladanein to dock strongly with L. infantum trypanothione reductase [386]. Ogungbe and co-workers [377] have found that dimeric flavonoids such as amentoflavone tetramethyl ether, bilobetin, isoginkgetin, and sciadopitysin (Figure 8), dock (MolDock) much more strongly to L. infantum trypanothione reductase than monomeric flavonoids, although these dimeric compounds generally violate Lipinski's rule of five [387]. The glycosylxanthone mangiferin was shown to dock (AutoDock) in the active site of L. infantum trypanothione reductase [388]. Prenylated xanthones have also demonstrated notably strong docking (MolDock) to L. infantum trypanothione reductase [377]. Of the polyphenolic ligands examined, Ogungbe and co-workers [377] found the flavonoids artonin B and cycloartobiloxanthone (Figure 8) to show selective docking to this protein target. Strongly docking (MolDock) terpenoid ligands for $L$. infantum trypanothione reductase included the cassane diterpenoids $6 \beta-O-2^{\prime} 3^{\prime}$-dihydrocinnamoyl-12hydroxy-(13)15-en-16,12-olide-18-cassaneoic acid and 6ß-O-cinnamoyl-12-hydroxy-(13)15-en-16,12olide-18-cassaneoic acid, and the limonoid 3-O-acetylkhayalactone (Figure 8) [375]. As part of her M.S. thesis, Ritika Chauhan developed a homology model of L. donovani trypanothione reductase and found curcumin (Figure 8) and curcumin derivatives to be strongly docking using AutoDock [389]. The alkaloid tomatidine (Figure 8), the aglycone of tomatine, from Solanum spp. was identified as a potential inhibitor of Leishmania infantum trypanothione reductase using molecular docking (AutoDock) by Venkatesan and Dubey [390]. Tomatidine is a known inhibitor of multidrug resistance transporter in human cancer cells [391] and a more recent report has indicated that tomatidine affects sterol biosynthesis in promastigotes of Leishmania amazonensis and can lead to mitochondrial dysfunction in those parasites [392]. There is no known published report on the inhibitory activity of the compound on trypanothione reductase, but the authors suggested that tomatidine has a structural scaffold that makes it a potential inhibitor of trypanothione reductase.

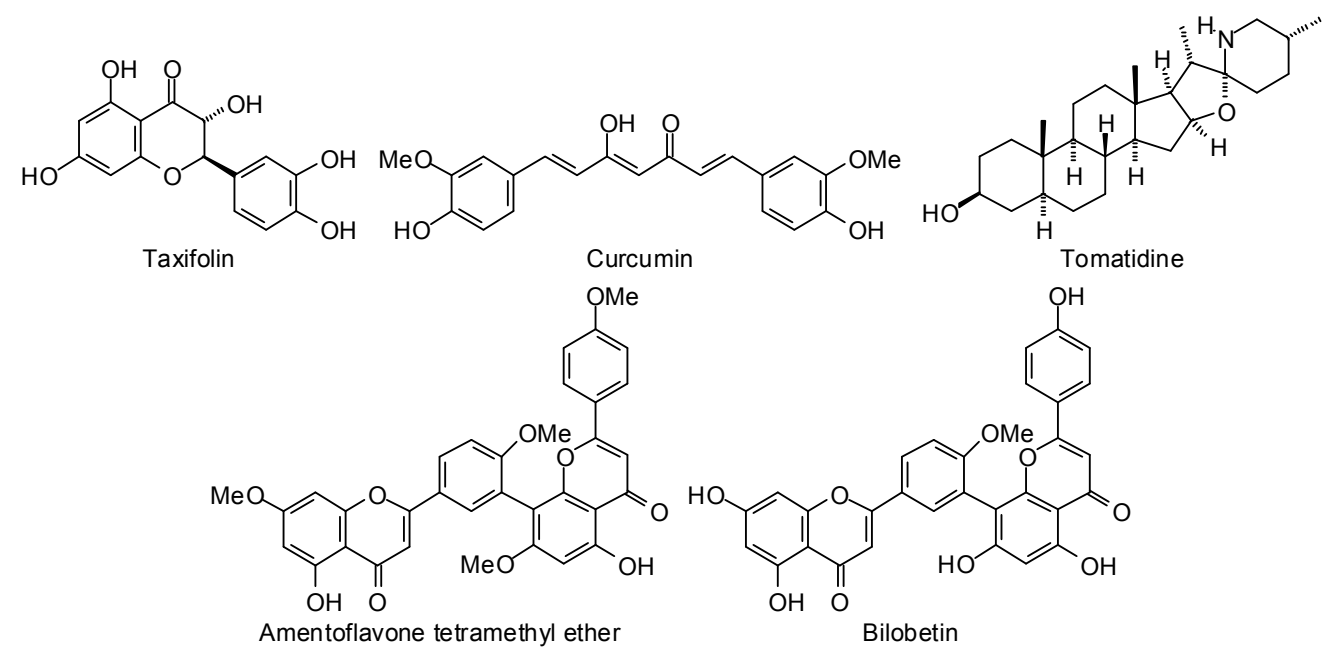

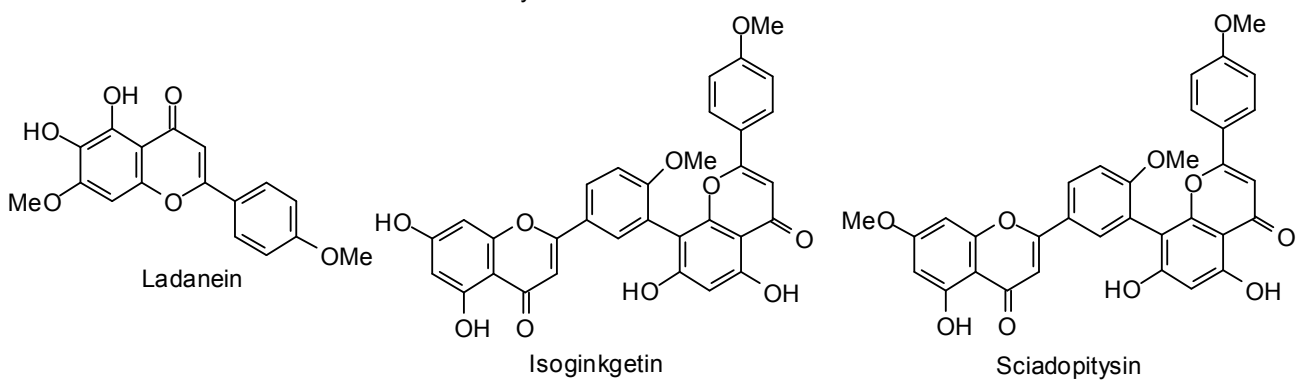

Figure 8. Cont. 


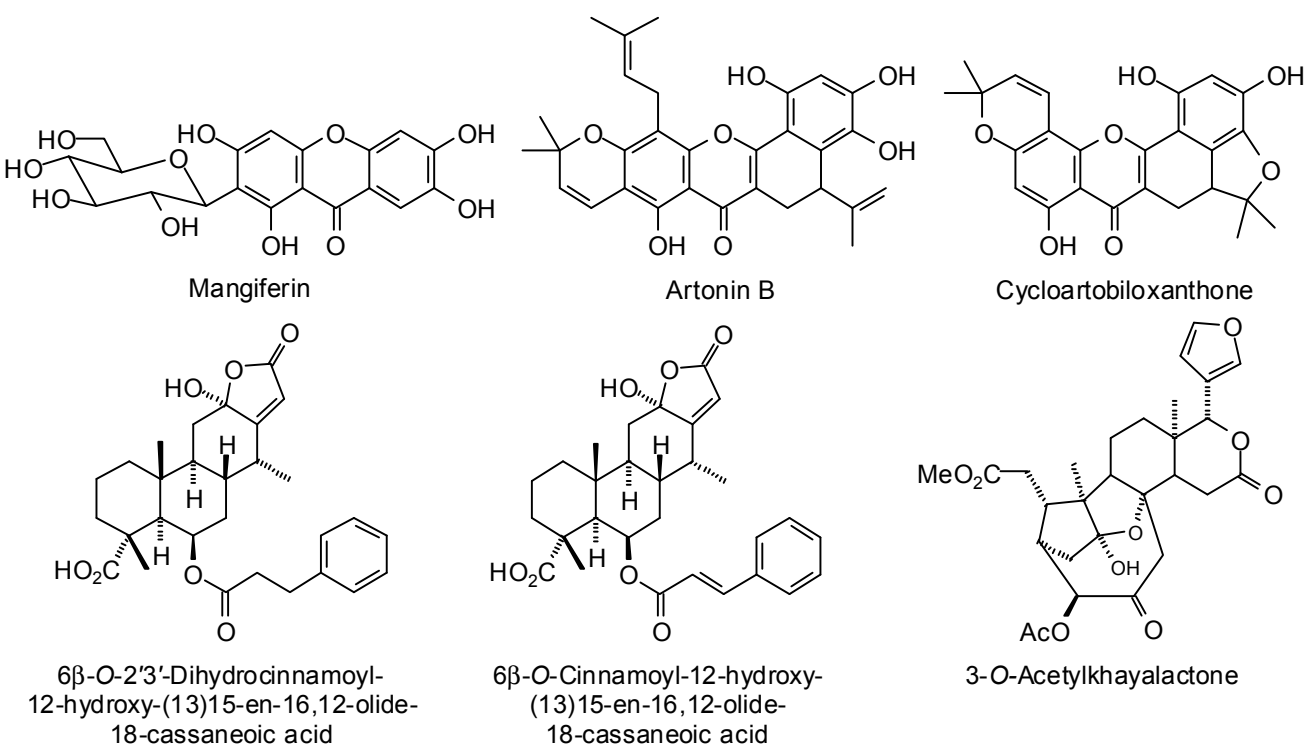

Figure 8. Phytochemical ligands with encouraging docking properties with Leishmania trypanothione reductase.

Several antitrypanosomal phytochemicals have shown strong docking (MolDock) to T. brucei trypanothione reductase, including the iridoid ningpogenin, the diacetylenes 8-hydroxyheptadeca-1 -ene-4,6-diyn-3-yl acetate and 8-hydroxyheptadeca-4,6-diyn-3-yl acetate, the flavonoid cissampeloflavone, the anthracenone vismione D, and aculeatin D (Figure 9) [393]. A number of Rauwolfia vomitoria indole alkaloids (ajmalimine, isoajmaline, mitoridine, normitoridine, nortetraphyllicine, and raucaffrinoline, Figure 9) have shown selective docking (MolDock) to this protein target [379]. Numerous phytochemicals have shown antiparasitic activity against T. cruzi [394] and a molecular docking study (MolDock) has revealed several of these to show selective docking to T. cruzi trypanothione reductase [380]. A number of flavonoids (galangin, luteolin, pinobanksin, pinocembrin, tectochrysin, and 5,6,7-trihydroxy-4'-methoxyflavone, Figure 9), as well as the lignan ganschisandrin, the diterpenoids 5-epi-icetexone, and the stilbenoid isonohalaenic acid (Figure 9), showed notable selective docking to T. cruzi trypanothione reductase. Additionally, several flexible, hydrophobic ligands, geranylgeraniol (Figure 9) and $C_{17}$ fatty alcohol derivatives from Persea americana, also docked strongly. In a similar study, the flavonoid tamarixetin showed strong selective docking to T. cruzi trypanothione reductase [386]. In a molecular docking search of alkaloids, Argüelles and co-workers concluded that quebrachamine, cephalotaxine, cryptolepine, tomatidine (Figure 8), solanidine, and solasodine (Figure 9) could serve as lead molecular scaffolds for T. cruzi trypanothione reductase inhibitors [395]. Likewise, the alkaloid asparagamine A docked selectively to both L. infantum and T. cruzi trypanothione reductase [396]. An AutoDock study by Saha and Sharma revealed the withanolide 18-acetoxy-5,6-deoxy-5-withenolide D and the steroidal alkaloid sarachine (Figure 9) to be strongly docking phytochemical ligands for T. cruzi trypanothione reductase [397].
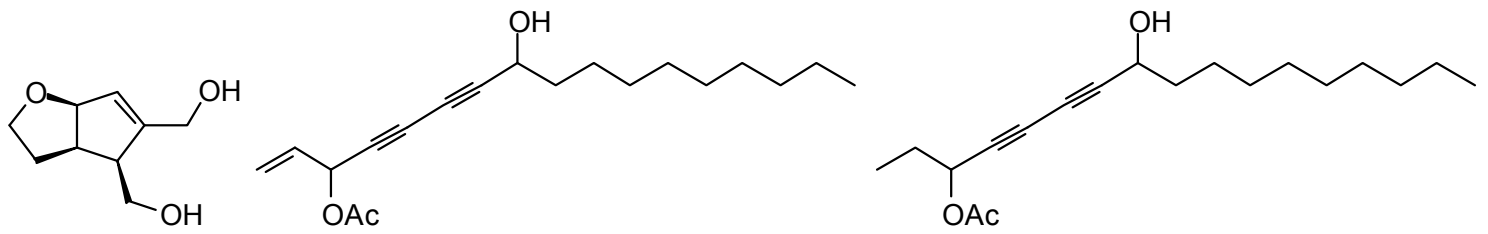

Ningpogenin 8-Hydroxyheptadeca-1-ene-4,6-diyn-3-yl acetate 8-Hydroxyheptadeca-4,6-diyn-3-yl acetate

Figure 9. Cont. 


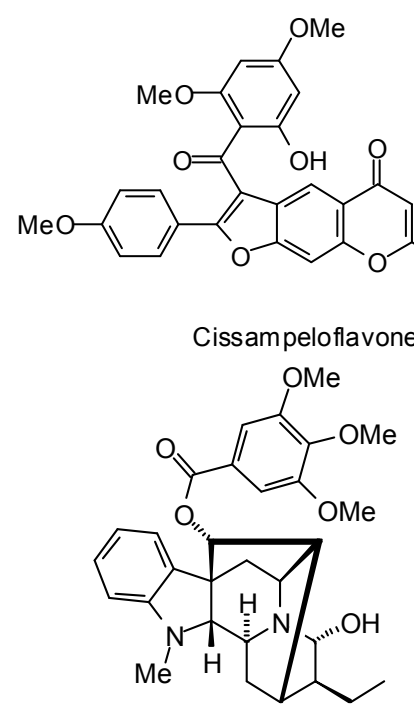

Ajmalimine

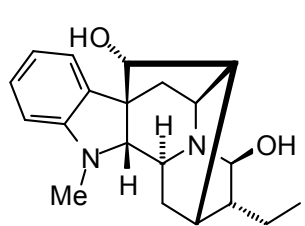

Isoajmaline<smiles>CC(C)=CCC/C(C)=C/COc1cc(O)c2c(O)c3c(cc2c1)C[C@](C)(O)CC3=O</smiles>

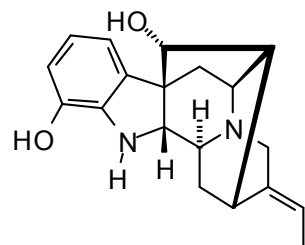

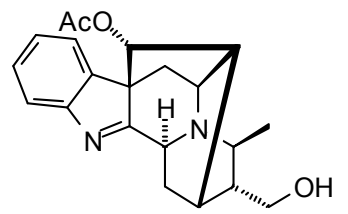<smiles>O=c1c(O)c(-c2ccccc2)oc2cc(O)cc(O)c12</smiles><smiles>O=c1cc(-c2ccc(O)c(O)c2)oc2cc(O)cc(O)c12</smiles>

Nortetraphyllicine

Raucaffrinoline

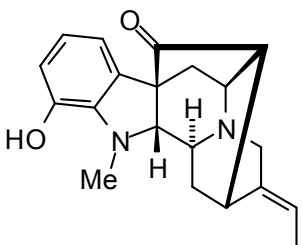

Mitoridine

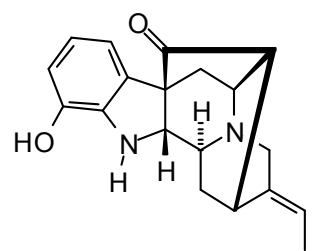

Normitoridine<smiles>O=C1c2c(O)cc(O)cc2OC(c2ccccc2)[C@@H]1O</smiles><smiles>O=C1CC(c2ccccc2)Oc2cc(O)cc(O)c21</smiles>

Galangin

Luteolin<smiles>COc1cc(O)c2c(=O)cc(-c3ccccc3)oc2c1</smiles><smiles>COc1ccc(-c2cc(=O)c3c(O)c(O)c(O)cc3o2)cc1</smiles>

Pinobanksin

Pinocembrin

Tectochrysin

5,6,7-Trihydroxy-4'-methoxyflavone<smiles>COc1ccc(C2O[C@@H](c3ccc(OC)c(OC)c3)C(C)C2C)cc1OC</smiles><smiles>COc1ccc(-c2oc3cc(O)cc(O)c3c(=O)c2O)cc1O</smiles>

Tamarixetin

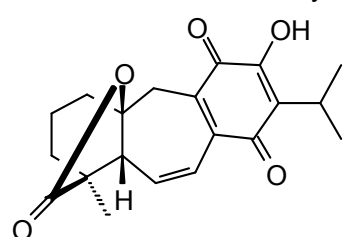

5-epi-Icetexone<smiles>CC[C@@]12CCCN(CCc3c([nH]c4ccccc34)C1)C2</smiles>

Quebrachamine<smiles>COc1ccc(CCc2cc(O)cc(OC)c2C(=O)O)cc1</smiles>

Isonoholaenic acid<smiles>COC1C[C@]23CCCN2CCc2cc4c(cc2[C@@H]3[C@H]1O)OCO4</smiles>

Cephalotaxine

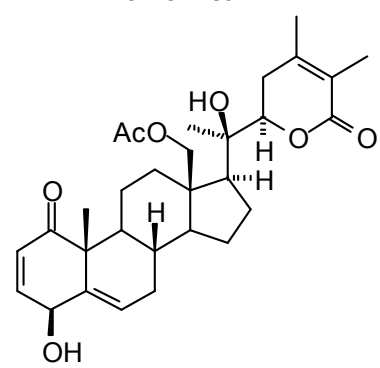

18-Acetoxy-5,6-deoxy-5-withenolide D<smiles>CC(C)=CCC/C(C)=C/CC/C(C)=C/CC/C(C)=C/CO</smiles>

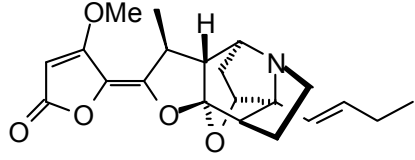

Asparagamine $\mathrm{A}$

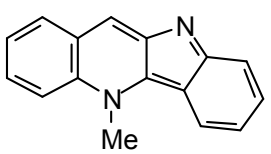

Cryptolepine

Figure 9. Cont. 


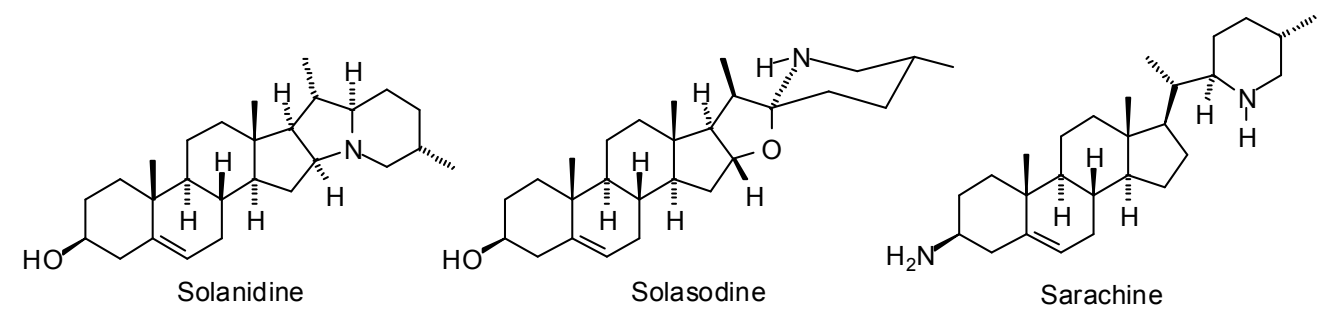

Figure 9. Phytochemical ligands with encouraging docking properties with Trypanosoma trypanothione reductase.

Parasitic trypanosomatids salvage pterins from their host organisms using pteridine reductase (PTR1), and this enzyme is a potential target for antiparasitic drug development [242]. Sahi and co-workers have carried out in vitro antileishmanial screening of constituents from Piper longum fruit and found the alkaloid piperlongumide (Figure 10) to be the most active compound [398]. A molecular docking study using a homology model for L. donovani PTR1 has suggested that this protein may be the target for piperlongumide. An in-silico screening study of antitrypanosomal phytochemicals has found the alkaloids $N$-methyltetrahydropalmatine, nordomesticine (Figure 10), and sarachine (Figure 9) to dock preferentially to T. cruzi pteridine reductase [380]. The bis-indole alkaloids flinderole B and flinderole C, as well as the steroidal alkaloid hookerianamide I (Figure 10) showed docking preferences for L. major pteridine reductase 1 [374]. Bernal and Coy-Barrera have examined several antileishmanial sesquiterpenoids for docking (AutoDock Vina) to L. major PTR1 and found pungiolide A, pungiolide B, and microlobidene (Figure 10), to be the strongest docking ligands [378]. In another study, the guaianolide sesquiterpenoid lactupicrin (Figure 10) docked strongly to L. major PTR1 [375].

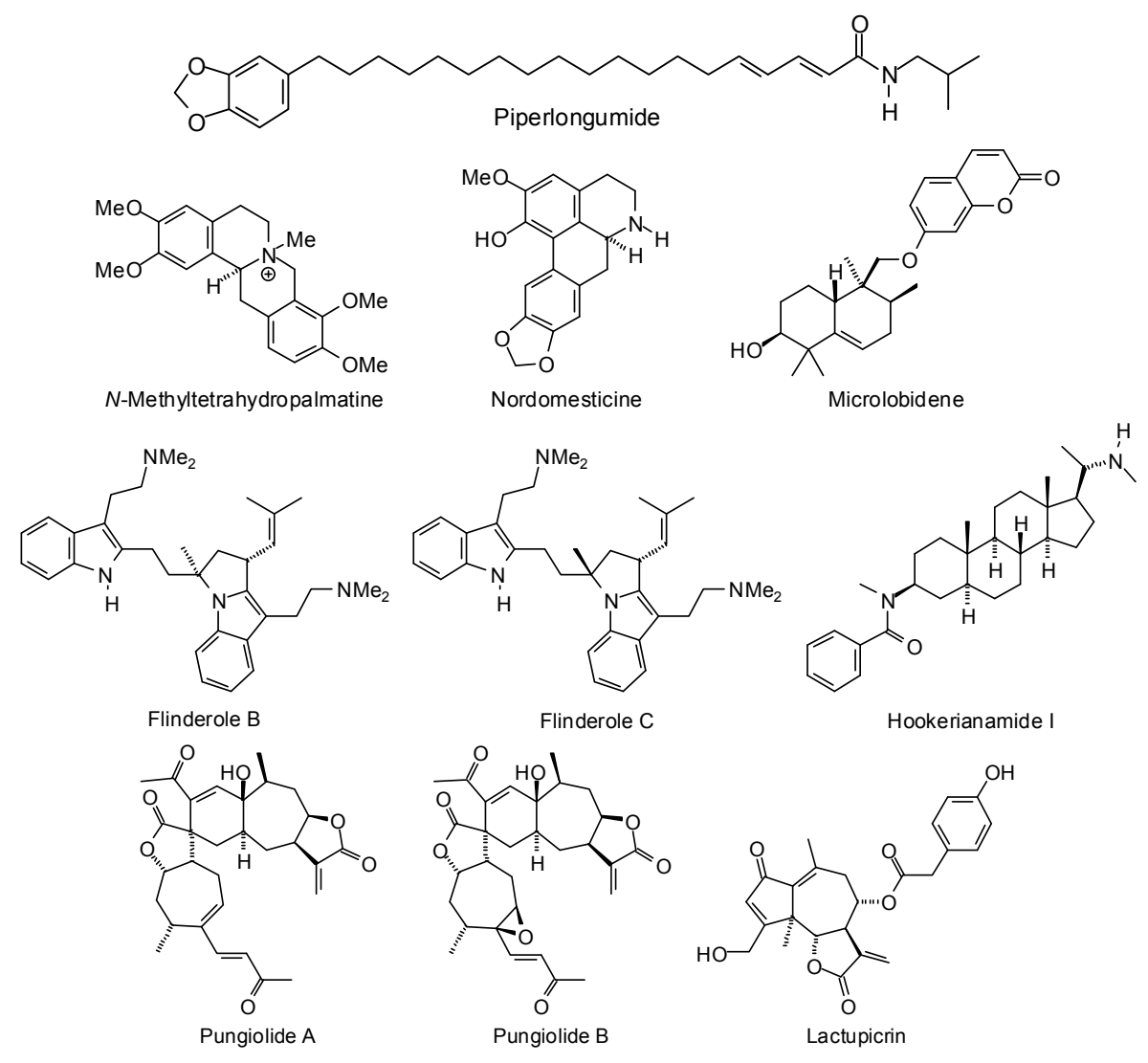

Figure 10. Phytochemical ligands with encouraging docking properties with parasite pteridine reductases. 
Herrmann and co-workers have carried out an in-silico screening of a natural products library of 700 structures against T. brucei glyceraldehyde-3-phosphate dehydrogenase (TbGAPDH) [399]. These investigators were able to identify 13 "hits" based on the molecular docking and of these, five compounds (three geranylated benzophenones, flavaspidic acid $\mathrm{AB}$, and a bis-resorcinyl tetradecene derivative, Figure 11) showed significant in vitro inhibitory activity against recombinant TbGAPDH as well as T. brucei rhodesiense.<smiles>CC(C)=CCC/C(C)=C/Cc1ccc(O)c(C(=O)c2c(O)cc(C(=O)O)cc2O)c1O</smiles><smiles>CCCC(=O)c1c(O)c(C)c(O)c(CC2=C(O)C(C)(C)C(O)=C(C(C)=O)C2=O)c1O</smiles><smiles>CC(C)=CCC/C(C)=C/Cc1ccc(O)c(C(=O)c2c(O)cc(C(=O)O)cc2C=O)c1O</smiles><smiles>Oc1cc(O)cc(CCC/C=C\CCCCCCCCCCc2cc(O)cc(O)c2)c1</smiles>

Figure 11. Phytochemical ligands with encouraging docking properties with Trypanosoma brucei glyceraldehyde 3-phosphate dehydrogenase.

An in-silico analysis of a dataset of 683 flavonoids for molecular docking to L. mexicana pyruvate kinase found that 3-glycosylated flavonoids (seven compounds), 6,8-diglycosyl flavonoids (one compound), and biflavonoids (four compounds) were the most promising ligands [400]. Promastigote surface antigen has been identified as a common protein drug target for L. braziliensis, L. major, and L. infantum. $N$-Acetylglucosamine was identified as a potential lead target molecule based on docking studies (ArgusDock) [401].

Inhibition of Trypanosoma cruzi silent-information regulator 2 proteins (sirtuins) is known to cause arrested growth of the parasite [402]. Sacconnay and co-workers assembled two conformational states of TcSir2rp1 using homology modeling and carried out molecular docking of a library of antitrypanosomal phytochemicals [403]. Four compounds were found to have particularly promising docking characteristics, (15:2)-anacardic acid, 3,18-diacetoxy-1-octadecene-4,6-diyne-8-ol, aculeatin D, and vismione D (Figure 12).
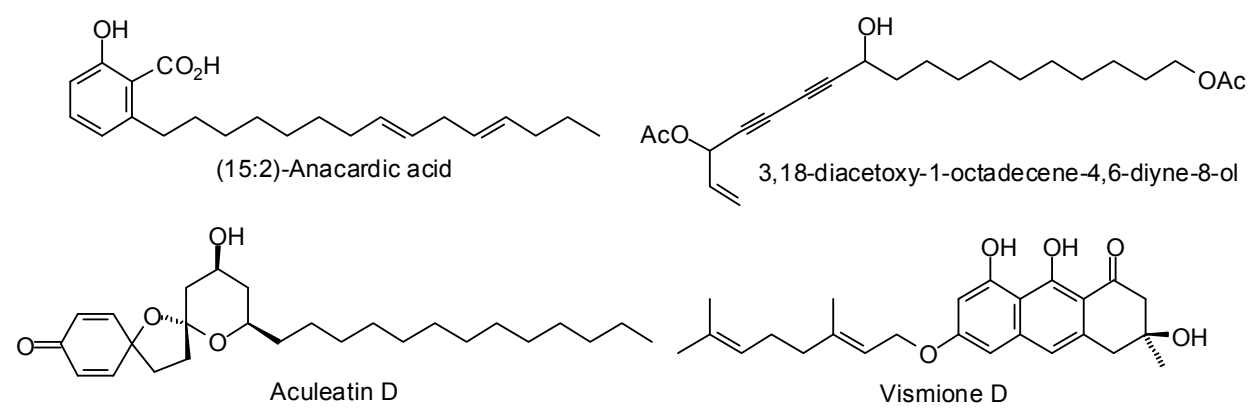

Figure 12. Phytochemical ligands with encouraging docking properties with Trypanosoma cruzi silent-information regulator 2 protein 1.

Leishmania lack the ability to synthesize purines de novo and therefore salvage purines. Adenosine kinase is one of the enzymes in the purine salvage pathway, and Leishmania adenosine kinase is crucial for parasite survival [404]. Molecular docking (Glide, FlexX, GOLD) of a library of natural products 
with a homology-modeled structure of $L$. donovani adenosine kinase has revealed 1,6-digalloylglucose and lawsone (Figure 13) as top hit phytochemical ligands [405].

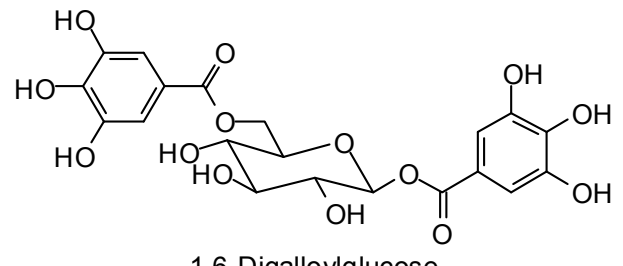

1,6-Digalloylglucose<smiles>O=C1C=C(O)C(=O)C2C(=O)OCC12</smiles>

Figure 13. Phytochemical ligands with encouraging docking properties with Leishmania donovani adenosine kinase.

\subsection{Plasmodium Targets}

Curcumin (Figure 8) has shown antimalarial activity $\left(\mathrm{IC}_{50} 5 \mu \mathrm{M}\right)$ against $P$. falciparum, and experimental evidence has suggested disruption of parasite microtubules to be responsible for the antiplasmodial activity [406]. Molecular docking studies (AutoDock) have revealed that curcumin interacts with homology-modeled P. falciparum tubulin dimer at the colchicine binding site of tubulin rather than the paclitaxel or vinblastine binding sites [406].

The sarco/endoplasmic reticulum $\mathrm{Ca}^{2+}$-ATPase orthologue of P. falciparum (PfATP6) has been suggested to be a viable drug target for antimalarial chemotherapy [407]. Homology modeling has allowed construction of the three-dimensional structure of PfATP6 and allowed molecular docking/ in-silico screening of potential antimalarial drugs, including artemisinin [408] and curcumin [409,410]. Curcumin has also shown selectively strong docking (MolDock) to L. major methionyl tRNA synthetase [377]. Bousejra-El Garah and co-workers, however, found no correlation between in silico docking energies to PfATP6 and antimalarial activities of several structurally diverse antimalarial compounds [411].

Kumar and co-workers have carried out a molecular docking examination (AutoDock) of several bioactive natural products with $P$. falciparum dihydrofolate reductase [376]. These workers found ochrolifuanine A, chrobisiamone A, ailanthinone, korupensamine A, butyraxanthone B, ancistrolikokine A, calothwaitesixanthone, 7-deacetylkhivorin, 5-prenylbutein, methyl 6-hydroxyangolensate, and aulacocarpin A (Figure 14), to show notable docking energies (i.e., lower than the co-crystallized inhibitor WR99210).

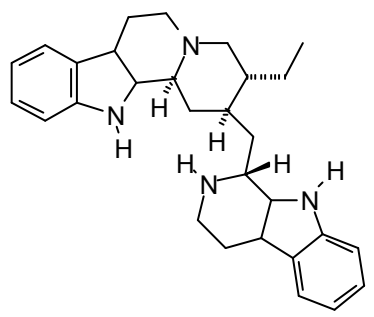

Ochrolifuanine A

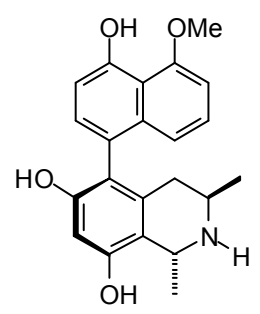

Korupensamine A<smiles>COc1cccc(C2CC(C)N(C)c3cc(O)cc(OC)c32)c1OC</smiles>

Ancistrolikokine A<smiles>CC(C)=CCc1cc(O)c2oc3ccc4c(c3c(=O)c2c1O)C=CC(C)(C)O4</smiles>

Calothwaitesixanthone

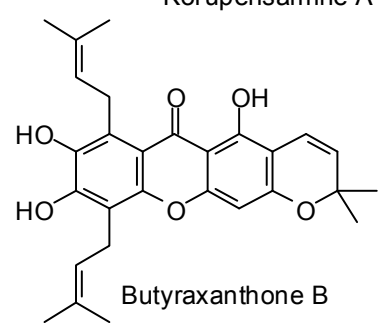<smiles>CC(=O)Cc1cc(O)cc2c1C(=O)CC(C)(Cc1cc(=O)c3c(CC(C)=O)cc(O)cc3o1)O2</smiles>

Chrobisiamone A

Figure 14. Cont. 

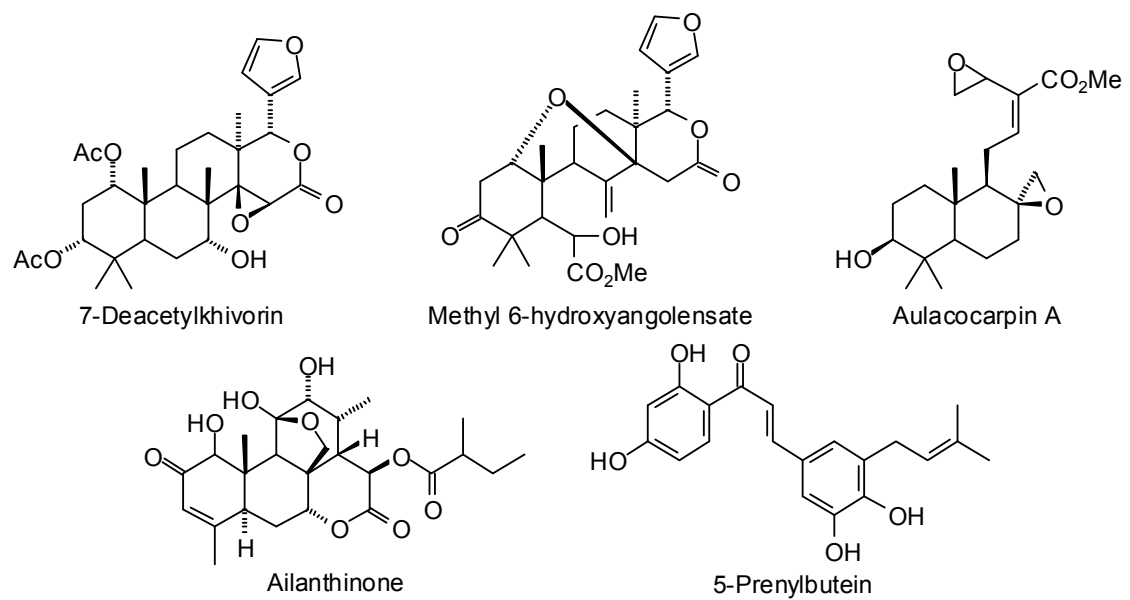

Figure 14. Phytochemical ligands with encouraging docking properties with Plasmodium falciparum dihydrofolate reductase.

Plasmodium lactate dehydrogenase has been identified as a potential drug target for antimalarials due to parasite dependence on glycolysis for ATP production [412]. Molecular docking of the tea flavonoid gallocatechin (Figure 15) to P. falciparum lactate dehydrogenase revealed strong docking, more strongly than either chloroquine or mefloquine, to the NADH binding site of the enzyme [413]. Glycyrrhetic acid (Figure 4) has exhibited notable ( $\mathrm{IC}_{50} 1.69 \mu \mathrm{g} / \mathrm{mL}$ ) in vitro antiplasmodial activity against $P$. falciparum, and docking studies (Discovery Studio) have also shown glycyrretic acid to dock moderately well to P. falciparum lactate dehydrogenase [414].<smiles>Oc1cc(O)c2c(c1)OC(c1cc(O)c(O)c(O)c1)C(O)C2</smiles>

Gallocatechin<smiles>CCN(CC)CCCC(C)Nc1ccnc2cc(Cl)ccc12</smiles>

Chloroquine<smiles>OC(c1cc(C(F)(F)F)nc2c(C(F)(F)F)cccc12)C1CCCCN1</smiles>

Mefloquine

Figure 15. Strongly docking ligands with Plasmodium falciparum lactate dehydrogenase.

(+)-Usnic acid, a secondary metabolite from lichen, was identified as an active and selective inhibitor of the liver stage form of Plasmodium berghei by Lauinger and co-workers [415]. In the molecular docking study to identify the binding affinities and binding sites of (+)-usnic acid and three other lichen secondary metabolites (evernic acid, vulpic acid, and psoromic acid, Figure 16) with Plasmodium type II fatty acid biosynthesis pathway (FAS-II) enzymes, these workers found that the mechanism of action of lichen acids on FAS-II may be different from those of previously described FAS-II enzymes inhibitors. The modeling study they carried out indicated that those compounds appear to inhibit FAS-II enzymes indirectly via binding to allosteric sites on the protein surface and not to the active sites of FAS-II enzymes. This indirect binding is speculated to possibly affect the enzyme conformations and subsequently interfere with the catalytic activities [415].

Enoyl-acyl carrier protein reductase is a critical enzyme in type II fatty acid biosynthesis in the hepatocyte-stage of Plasmodium falciparum. Tallorin and co-workers, based on molecular docking and subsequent in vitro screening, have identified celestrol as a potent PfENR inhibitor [416]. Using molecular docking (AutoDock) coupled with three-dimensional quantitative structure activity relationships (3D-QSAR), Wadhwa and co-workers identified five phytochemicals ( $3 \alpha, 20$-lupanediol, ergosterol peroxide, 24-methylenecycloartan-3-ol, 2'-epicycloisobrachycoumarinone epoxide, and atalaphyllidine, Figure 16) as potential PfENR inhibitors [417]. 


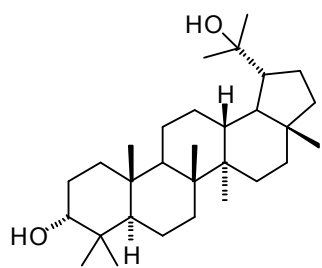

$3 \alpha, 20$-Lupanediol<smiles>CC(C)C(C)CCC(C)C1CCC2C3CCC4(CCC(O)CC4)C3CCC12C</smiles>

Ergosterol peroxide<smiles>C=C(C)C(C)CCC(C)C1CCC2C3CCC4(C)C(C)CCCC4(C)C3CCC12C</smiles>

24-Methylenecycloartan-3-ol<smiles></smiles>

2'-Epicycloisobrachycoumarinone epoxide

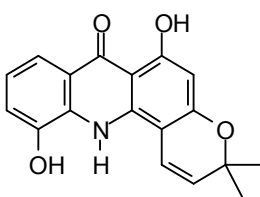

Atalaphyllidine

Figure 16. Phytochemical ligands with encouraging docking properties with Plasmodium type II fatty acid biosynthesis pathway enzymes.

Recently, Gupta and co-workers have used homology modeling to construct parasitic mitogen-activated protein kinases (MAPKs) for Leishmania mexicana, Plasmodium falciparum, and Trypanosoma brucei [418]. These workers carried out a molecular docking study on a small library of 10 antiparasitic phytochemicals. Of these, aspidocarpine showed excellent docking to both LmxMPK4 and TbMAPK5, and cubebin and eupomatenoid 5 (Figure 17) both docked well with PfMAK2.
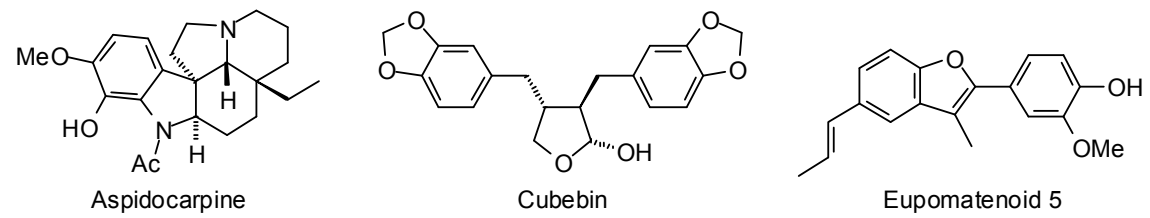

Figure 17. Phytochemical ligands with encouraging docking properties with parasitic mitogen-activated protein kinases.

\section{Conclusions}

This review has catalogued the numerous druggable parasitic protein targets, with more being identified and three-dimensional structures determined, allowing many potential sites for identification and development of new and selective inhibitors. The theoretical predictions need to be experimentally validated, and the results can be used to guide an effective development of selective and targeted natural products analogues. A perusal of the structures in this review reveals several of the phytochemical ligands with promising docking properties are not likely to have suitable drug-like properties. Therefore, pharmacokinetic and pharmacodymanic studies as well as structure-based design and optimization studies are needed to resolve issues of bioavailability and selectivity. It is advisable to carry out additional filtering for "drug-likeness" [387,419,420], ADME [421], and toxicity prediction [422].

Acknowledgments: This work was performed as part of the activities of the Research Network Natural Products against Neglected Diseases (ResNet-NPND), http:/ /www.uni-muenster.de/ResNetNPND/index.html.

Author Contributions: I.V.O. and W.N.S. both contributed to the writing of this review.

Conflicts of Interest: The authors declare no conflict of interest.

\section{References}

1. Murray, C.J.L.; Rosenfeld, L.C.; Lim, S.S.; Andrews, K.G.; Foreman, J.K.; Haring, D.; Fullman, N.; Naghavi, M.; Lozano, R.; Lopez, A.D. Global malaria mortality between 1980 and 2010: A systematic analysis. Lancet 2012, 379, 413-431. [CrossRef] 
2. Rassi, A., Jr.; Rassi, A.; Marin-Neto, J.A. Chagas disease. Lancet 2010, 375, 1388-1402. [CrossRef]

3. Brun, R.; Blum, J.; Chappuis, F.; Burri, C. Human African trypanosomiasis. Lancet 2010, 375, $148-159$. [CrossRef]

4. Alvar, J.; Vélez, I.D.; Bern, C.; Herrero, M.; Desjeux, P.; Cano, J.; Jannin, J.; den Boer, M.; The WHO Leishmaniasis Control Team. Leishmaniasis worldwide and global estimates of its incidence. PLoS ONE 2012, 7, e35671. [CrossRef] [PubMed]

5. Burrows, J.N.; Waterson, D. Discovering new medicines to control and eradicate malaria. Top. Med. Chem. 2011, 7, 125-180.

6. Coura, J.R.; de Castro, S.L. A critical review on Chagas disease chemotherapy. Mem. Inst. Oswaldo Cruz 2002, 97, 3-24. [CrossRef]

7. Fairlamb, A.H. Chemotherapy of human African trypanosomiasis: Current and future prospects. Trends Parasitol. 2003, 19, 488-494. [CrossRef] [PubMed]

8. Croft, S.L.; Olliaro, P. Leishmaniasis chemotherapy-Challenges and opportunities. Clin. Microbiol. Infect. 2011, 17, 1478-1483. [CrossRef] [PubMed]

9. Harvey, A.L.; Edrada-Ebal, R.A.; Quinn, R.J. The re-emergence of natural products for drug discovery in the genomics era. Nat. Rev. Drug Discov. 2015, 14, 111-129. [CrossRef] [PubMed]

10. Schmidt, T.J.; Khalid, S.A.; Romanha, A.J.; Alves, T.M.A.; Biavatti, M.W.; Brun, R.; da Costa, F.B.; de Castro, S.L.; Ferreira, V.F.; de Lacerda, M.V.G.; et al. The potential of secondary metabolites from plants as drugs or leads against protozoan neglected diseases-Part I. Curr. Med. Chem. 2012, 19, 2128-2175. [PubMed]

11. Schmidt, T.J.; Khalid, S.A.; Romanha, A.J.; Alves, T.M.A.; Biavatti, M.W.; Brun, R.; da Costa, F.B.; de Castro, S.L.; Ferreira, V.F.; de Lacerda, M.V.G.; et al. The potential of secondary metabolites from plants as drugs or leads against protozoan neglected diseases-Part II. Curr. Med. Chem. 2012, 19, 2176-2228. [CrossRef] [PubMed]

12. Annang, F.; Genilloud, O.; Vicente, F. Contribution of natural products to drug discovery in tropical diseases. In Comprehensive Analysis of Parasite Biology: From Metabolism to Drug Discovery; Müller, S., Cerdan, R., Radulescu, O., Eds.; Wiley-VCH: Weinheim, Germany, 2016; pp. 75-104.

13. Rosén, J.; Gottfries, J.; Muresan, S.; Backlund, A.; Oprea, T.I. Novel chemical space exploration via natural products. J. Med. Chem. 2009, 52, 1953-1962. [CrossRef] [PubMed]

14. Feher, M.; Schmidt, J.M. Property distributions: Differences between drugs, natural products, and molecules from combinatorial chemistry. J. Chem. Inform. Comput. Sci. 2003, 43, 218-227. [CrossRef] [PubMed]

15. Ganesan, A. The impoact of natural products upon modern drug discovery. Curr. Opin. Chem. Biol. 2008, 12, 306-317. [CrossRef] [PubMed]

16. Keller, T.H.; Pichota, A.; Yin, Z. A practical view of 'druggability'. Curr. Opin. Chem. Biol. 2006, 10, $357-361$. [CrossRef] [PubMed]

17. Newman, D.J.; Cragg, G.M. Natural products as sources of new drugs over the 30 years from 1981 to 2010. J. Nat. Prod. 2012, 75, 311-335. [CrossRef] [PubMed]

18. Phillips, C.L.; Ullman, B.; Brennan, R.G.; Hill, C.P. Crystal structures of adenine phosphoribosyltransferase from Leishmania donovani. EMBO J. 1999, 18, 3533-3545. [CrossRef] [PubMed]

19. Kuettel, S.; Greenwald, J.; Kostrewa, D.; Ahmed, S.; Scapozza, L.; Perozzo, R. Crystal structures of T. $b$. rhodesiense adenosine kinase complexed with inhibitor and activator: Implications for catalysis and hyperactivation. PLoS Negl. Trop. Dis. 2011, 5, e1164. [CrossRef] [PubMed]

20. Timm, J.; González-Pacanowska, D.; Wilson, K.S. Structures of adenosine kinase from Trypanosoma brucei brucei. Acta Crystallogr. F Struct. Biol. Commun. 2014, 70, 34-39. [CrossRef] [PubMed]

21. Eaazhisai, K.; Jayalakshmi, R.; Gayathri, P.; Anand, R.P.; Sumathy, K.; Balaram, H.; Murthy, M.R. Crystal structure of fully ligated adenylosuccinate synthetase from Plasmodium falciparum. J. Mol. Biol. 2004, 335, 1251-1264. [CrossRef] [PubMed]

22. Wernimont, A.K.; Osman, K.T.; Loppnau, P.; Arrowsmith, C.H.; Edwards, A.M.; Bountra, C.; Hui, R.; Lin, Y.H. Crystal Structure of an M17 aminopeptidase from Trypanosoma brucei, Tb427tmp.02.4440. Unpublished work, 2012, doi:10.2210/pdb4efd/pdb.

23. Vulliez-Le Normand, B.; Tonkin, M.L.; Lamarque, M.H.; Langer, S.; Hoos, S.; Roques, M.; Saul, F.A.; Faber, B.W.; Bentley, G.A.; Boulanger, M.J.; et al. Structural and functional insights into the malaria parasite moving junction complex. PLoS Pathog. 2012, 8, e1002755. [CrossRef] [PubMed] 
24. D'Antonio, E.L.; Ullman, B.; Roberts, S.C.; Dixit, U.G.; Wilson, M.E.; Hai, Y.; Christianson, D.W. Crystal structure of arginase from Leishmania mexicana and implications for the inhibition of polyamine biosynthesis in parasitic infections. Arch. Biochem. Biophys. 2013, 535, 163-176. [CrossRef] [PubMed]

25. Dowling, D.P.; Ilies, M.; Olszewski, K.L.; Portugal, S.; Mota, M.M.; Llinás, M.; Christianson, D.W. Crystal structure of arginase from Plasmodium falciparum and implications for L-arginine depletion in malarial infection. Biochemistry 2010, 49, 5600-5608. [CrossRef] [PubMed]

26. Ilies, M.; Di Costanzo, L.; Dowling, D.P.; Thorn, K.J.; Christianson, D.W. Binding of $\alpha$, $\alpha$-disubstituted amino acids to arginase suggests new avenues for inhibitor design. J. Med. Chem. 2011, 54, 5432-5443. [CrossRef] [PubMed]

27. Fernandez, P.; Haouz, A.; Pereira, C.A.; Aguilar, C.; Alzari, P.M. The crystal structure of Trypanosoma cruzi arginine kinase. Proteins 2007, 69, 209-212. [CrossRef] [PubMed]

28. Wrenger, C.; Müller, I.B.; Schifferdecker, A.J.; Jain, R.; Jordanova, R.; Groves, M.R. Specific inhibition of the aspartate aminotransferase of Plasmodium falciparum. J. Mol. Biol. 2011, 405, 956-971. [CrossRef] [PubMed]

29. Hain, A.U.; Weltzer, R.R.; Hammond, H.; Jayabalasingham, B.; Dinglasan, R.R.; Graham, D.R.; Colquhoun, D.R.; Coppens, I.; Bosch, J. Structural characterization and inhibition of the Plasmodium Atg8-Atg3 interaction. J. Struct. Biol. 2012, 180, 551-562. [CrossRef] [PubMed]

30. Kerr, I.D.; Wu, P.; Marion-Tsukamaki, R.; Mackey, Z.B.; Brinen, L.S. Crystal Structures of TbCatB and rhodesain, potential chemotherapeutic targets and major cysteine proteases of Trypanosoma brucei. PLoS Negl. Trop. Dis. 2010, 4, e701. [CrossRef] [PubMed]

31. Koopmann, R.; Cupelli, K.; Redecke, L.; Nass, K.; Deponte, D.P.; White, T.A.; Stellato, F.; Rehders, D.; Liang, M.; Andreasson, J.; et al. In vivo protein crystallization opens new routes in structural biology. Nat. Methods 2012, 9, 259-262. [CrossRef] [PubMed]

32. Redecke, L.; Nass, K.; DePonte, D.P.; White, T.A.; Rehders, D.; Barty, A.; Stellato, F.; Liang, M.; Barends, T.R.; Boutet, S.; et al. Natively inhibited Trypanosoma brucei cathepsin B structure determined by using an X-ray laser. Science 2013, 339, 227-230. [CrossRef] [PubMed]

33. Wernimont, A.K.; Pizarro, J.C.; Artz, J.D.; Amaya, M.F.; Xiao, T.; Lew, J.; Wasney, G.; Senesterra, G.; Kozieradzki, I.; Cossar, D.; et al. Crystal structure of choline kinase from Plasmodium Falciparum, PF14_0020. Unpublished work, 2009, doi:10.2210/pdb3fi8/pdb.

34. Gillmor, S.A.; Craik, C.S.; Fletterick, R.J. Structural determinants of specificity in the cysteine protease cruzain. Protein Sci. 1997, 6, 1603-1611. [CrossRef] [PubMed]

35. Brinen, L.S.; Hansell, E.; Cheng, J.; Roush, W.R.; McKerrow, J.H.; Fletterick, R.J. A target within the target: Probing cruzain's P1' site to define structural determinants for the Chagas' disease protease. Structure 2000, 8, 831-840. [CrossRef]

36. Huang, L.; Brinen, L.S.; Ellman, J.A. Crystal structures of reversible ketone-based inhibitors of the cysteine protease cruzain. Bioorg. Med. Chem. 2003, 11, 21-92. [CrossRef]

37. Choe, Y.; Brinen, L.S.; Price, M.S.; Engel, J.C.; Lange, M.; Grisostomi, C.; Weston, S.G.; Pallai, P.V.; Cheng, H.; Hardy, L.W.; et al. Development of $\alpha$-keto-based inhibitors of cruzain, a cysteine protease implicated in Chagas disease. Bioorg. Med. Chem. 2005, 13, 2141-2156. [CrossRef] [PubMed]

38. Kerr, I.D.; Lee, J.H.; Farady, C.J.; Marion, R.; Rickert, M.; Sajid, M.; Pandey, K.C.; Caffrey, C.R.; Legac, J.; Hansell, E.; et al. Vinyl sulfones as antiparasitic agents and a structural basis for drug design. J. Biol. Chem. 2009, 284, 25697-25703. [CrossRef] [PubMed]

39. Bryant, C.; Kerr, I.D.; Debnath, M.; Ang, K.K.; Ratnam, J.; Ferreira, R.S.; Jaishankar, P.; Zhao, D.; Arkin, M.R.; McKerrow, J.H.; et al. Novel non-peptidic vinylsulfones targeting the S2 and S3 subsites of parasite cysteine proteases. Bioorg. Med. Chem. Lett. 2009, 19, 6218-6221. [CrossRef] [PubMed]

40. Mott, B.T.; Ferreira, R.S.; Simeonov, A.; Jadhav, A.; Ang, K.K.; Leister, W.; Shen, M.; Silveira, J.T.; Doyle, P.S.; Arkin, M.R.; et al. Identification and optimization of inhibitors of Trypanosomal cysteine proteases: Cruzain, rhodesain, and TbCatB. J. Med. Chem. 2010, 53, 52-60. [CrossRef] [PubMed]

41. Brak, K.; Kerr, I.D.; Barrett, K.T.; Fuchi, N.; Debnath, M.; Ang, K.; Engel, J.C.; McKerrow, J.H.; Doyle, P.S.; Brinen, L.S.; et al. Nonpeptidic tetrafluorophenoxymethyl ketone cruzain inhibitors as promising new leads for Chagas disease chemotherapy. J. Med. Chem. 2010, 53, 1763-1773. [CrossRef] [PubMed]

42. Chen, Y.T.; Brinen, L.S.; Kerr, I.D.; Hansell, E.; Doyle, P.S.; McKerrow, J.H.; Roush, W.R. In vitro and in vivo studies of the trypanocidal properties of WRR-483 against Trypanosoma cruzi. PLoS Negl. Trop. Dis. 2010, 4, e825. [CrossRef] [PubMed] 
43. Wiggers, H.J.; Rocha, J.R.; Fernandes, W.B.; Sesti-Costa, R.; Carneiro, Z.A.; Cheleski, J.; da Silva, A.B.; Juliano, L.; Cezari, M.H.; Silva, J.S.; et al. Non-peptidic cruzain inhibitors with trypanocidal activity discovered by virtual screening and in vitro assay. PLoS Negl. Trop. Dis. 2013, 7, e2370. [CrossRef] [PubMed]

44. Brinen, L.S.; Gillmor, S.A.; Fletterick, R.J. Crystal structures of cruzain bound to three different substrates. Unpublished work, 2003, doi:10.2210/pdb1ewl/pdb, doi:10.2210/pdb1ewm/pdb, doi:10.2210/ $\mathrm{pdb} 1 \mathrm{ewo} / \mathrm{pdb}$.

45. Venugopal, V.; Datta, A.K.; Bhattacharyya, D.; Dasgupta, D.; Banerjee, R. Structure of cyclophilin from Leishmania donovani bound to cyclosporin at $2.6 \AA$ resolution: Correlation between structure and thermodynamic data. Acta Crystallogr. D Biol. Crystallogr. 2009, 65, 1187-1195. [CrossRef] [PubMed]

46. Arakaki, T.L.; Merritt, E.A. Cyclophilin from Leishmania major. Unpublished work, 2006, doi:10.2210/ $\mathrm{pdb} 2 \mathrm{hqj} / \mathrm{pdb}$.

47. Peterson, M.R.; Hall, D.R.; Berriman, M.; Nunes, J.A.; Leonard, G.A.; Fairlamb, A.H.; Hunter, W.N. The three-dimensional structure of a Plasmodium falciparum cyclophilin in complex with the potent anti-malarial cyclosporin A. J. Mol. Biol. 2000, 298, 123-133. [CrossRef] [PubMed]

48. Fyfe, P.K.; Westrop, G.D.; Ramos, T.; Müller, S.; Coombs, G.H.; Hunter, W.N. Structure of Leishmania major cysteine synthase. Acta Crystallogr. Sect. F Struct. Biol. Cryst. Commun. 2012, 68, 738-743. [CrossRef] [PubMed]

49. Hemsworth, G.R.; Moroz, O.V.; Fogg, M.J.; Scott, B.; Bosch-Navarrete, C.; González-Pacanowska, D.; Wilson, K.S. The crystal structure of the Leishmania major deoxyuridine triphosphate nucleotidohydrolase in complex with nucleotide analogues, dUMP, and deoxyuridine. J. Biol. Chem. 2011, 286, 16470-16481. [CrossRef] [PubMed]

50. Whittingham, J.L.; Leal, I.; Nguyen, C.; Kasinathan, G.; Bell, E.; Jones, A.F.; Berry, C.; Benito, A.; Turkenburg, J.P.; Dodson, E.J.; et al. dUTPase as a platform for antimalarial drug design: Structural basis for the selectivity of a class of nucleoside inhibitors. Structure 2005, 13, 329-338. [CrossRef] [PubMed]

51. Baragaña, B.; McCarthy, O.; Sánchez, P.; Bosch-Navarrete, C.; Kaiser, M.; Brun, R.; Whittingham, J.L.; Roberts, S.M.; Zhou, X.X.; Wilson, K.S.; et al. $\beta$-Branched acyclic nucleoside analogues as inhibitors of Plasmodium falciparum dUTPase. Bioorg. Med. Chem. 2011, 19, 2378-2391. [CrossRef] [PubMed]

52. Hampton, S.E.; Baragaña, B.; Schipani, A.; Bosch-Navarrete, C.; Musso-Buendía, J.A.; Recio, E.; Kaiser, M.; Whittingham, J.L.; Roberts, S.M.; Shevtsov, M.; et al. Design, synthesis, and evaluation of $5^{\prime}$-diphenyl nucleoside analogues as inhibitors of the Plasmodium falciparum dUTPase. ChemMedChem 2011, 6, 1816-1831. [CrossRef] [PubMed]

53. Hemsworth, G.R.; González-Pacanowska, D.; Wilson, K.S. On the catalytic mechanism of dimeric dUTPases. Biochem. J. 2013, 456, 81-88. [CrossRef] [PubMed]

54. Harkiolaki, M.; Dodson, E.J.; Bernier-Villamor, V.; Turkenburg, J.P.; González-Pacanowska, D.; Wilson, K.S. The crystal structure of Trypanosoma cruzi dUTPase reveals a novel dUTP/dUDP binding fold. Structure 2004, 12, 41-53. [CrossRef] [PubMed]

55. Almo, S.C.; Bonanno, J.B.; Sauder, J.M.; Emtage, S.; Dilorenzo, T.P.; Malashkevich, V.; Wasserman, S.R.; Swaminathan, S.; Eswaramoorthy, S.; Agarwal, R.; et al. Structural genomics of protein phosphatases. J. Struct. Funct. Genom. 2007, 8, 121-140. [CrossRef] [PubMed]

56. Yuvaniyama, J.; Chitnumsub, P.; Kamchonwongpaisan, S.; Vanichtanankul, J.; Sirawaraporn, W.; Taylor, P.; Walkinshaw, M.D.; Yuthavong, Y. Insights into antifolate resistance from malarial DHFR-TS structures. Nat. Struct. Biol. 2003, 10, 357-365. [CrossRef] [PubMed]

57. Dasgupta, T.; Chitnumsub, P.; Kamchonwongpaisan, S.; Maneeruttanarungroj, C.; Nichols, S.E.; Lyons, T.M.; Tirado-Rives, J.; Jorgensen, W.L.; Yuthavong, Y.; Anderson, K.S. Exploiting structural analysis, in silico screening, and serendipity to identify novel inhibitors of drug-resistant falciparum malaria. ACS Chem. Biol. 2009, 4, 29-40. [CrossRef] [PubMed]

58. Vanichtanankul, J.; Taweechai, S.; Yuvaniyama, J.; Vilaivan, T.; Chitnumsub, P.; Kamchonwongpaisan, S.; Yuthavong, Y. Trypanosomal dihydrofolate reductase reveals natural antifolate resistance. ACS Chem. Biol. 2011, 6, 905-911. [CrossRef] [PubMed]

59. Vanichtanankul, J.; Taweechai, S.; Uttamapinant, C.; Chitnumsub, P.; Vilaivan, T.; Yuthavong, Y.; Kamchonwongpaisan, S. Combined spatial limitation around residues 16 and 108 of Plasmodium falciparum dihydrofolate reductase explains resistance to cycloguanil. Antimicrob. Agents Chemother. 2012, 56, 3928-3935. [CrossRef] [PubMed] 
60. Yuthavong, Y.; Tarnchompoo, B.; Vilaivan, T.; Chitnumsub, P.; Kamchonwongpaisan, S.; Charman, S.A.; McLennan, D.N.; White, K.L.; Vivas, L.; Bongard, E.; et al. Malarial dihydrofolate reductase as a paradigm for drug development against a resistance-compromised target. Proc. Natl. Acad. Sci. USA 2012, 109, 16823-16828. [CrossRef] [PubMed]

61. Schormann, N.; Senkovich, O.; Walker, K.; Wright, D.L.; Anderson, A.C.; Rosowsky, A.; Ananthan, S.; Shinkre, B.; Velu, S.; Chattopadhyay, D. Structure-based approach to pharmacophore identification, in silico screening, and three-dimensional quantitative structure-activity relationship studies for inhibitors of Trypanosoma cruzi dihydrofolate reductase function. Proteins 2008, 73, 889-901. [CrossRef] [PubMed]

62. Senkovich, O.; Schormann, N.; Chattopadhyay, D. Structures of dihydrofolate reductase-thymidylate synthase of Trypanosoma cruzi in the folate-free state and in complex with two antifolate drugs, trimetrexate and methotrexate. Acta Crystallogr. D Biol. Crystallogr. 2009, 65, 704-716. [CrossRef] [PubMed]

63. Schormann, N.; Velu, S.E.; Murugesan, S.; Senkovich, O.; Walker, K.; Chenna, B.C.; Shinkre, B.; Desai, A.; Chattopadhyay, D. Synthesis and characterization of potent inhibitors of Trypanosoma cruzi dihydrofolate reductase. Bioorg. Med. Chem. 2010, 18, 4056-4066. [CrossRef] [PubMed]

64. Arakaki, T.L.; Merritt, E.A.; Ullman, B.; Yates, P.A. Crystal structure of dihydroorotate dehydrogenase from Leishmania donovani. Unpublished work, 2008, doi:10.2210/pdb3c61/pdb.

65. Cheleski, J.; Rocha, J.R.; Pinheiro, M.P.; Wiggers, H.J.; da Silva, A.B.; Nonato, M.C.; Montanari, C.A. Novel insights for dihydroorotate dehydrogenase class 1A inhibitors discovery. Eur. J. Med. Chem. 2010, 45, 5899-5909. [CrossRef] [PubMed]

66. Cordeiro, A.T.; Feliciano, P.R.; Pinheiro, M.P.; Nonato, M.C. Crystal structure of dihydroorotate dehydrogenase from Leishmania major. Biochimie 2012, 94, 1739-1748. [CrossRef] [PubMed]

67. Pinheiro, M.P.; Emery, F.S.; Nonato, M.C. Target sites for the design of anti-trypanosomatid drugs based on the structure of dihydroorotate dehydrogenase. Curr. Pharm. Des. 2013, 19, 2615-2627. [CrossRef] [PubMed]

68. Cordeiro, A.T.; Feliciano, P.R.; Nonato, M.C. Crystal structure of Leishmania major dihydroorotate dehydrogenase. Unpublished work, 2010, doi:10.2210/pdb3gye/pdb, doi:10.2210/pdb3gz3/pdb.

69. Hurt, D.E.; Widom, J.; Clardy, J. Structure of Plasmodium falciparum dihydroorotate dehydrogenase with a bound inhibitor. Acta Crystallogr. D Biol. Crystallogr. 2006, 62, 312-323. [CrossRef] [PubMed]

70. Deng, X.; Gujjar, R.; El Mazouni, F.; Kaminsky, W.; Malmquist, N.A.; Goldsmith, E.J.; Rathod, P.K.; Phillips, M.A. Structural plasticity of malaria dihydroorotate dehydrogenase allows selective binding of diverse chemical scaffolds. J. Biol. Chem. 2009, 284, 26999-27009. [CrossRef] [PubMed]

71. Booker, M.L.; Bastos, C.M.; Kramer, M.L.; Barker, R.H.; Skerlj, R.; Sidhu, A.B.; Deng, X.; Celatka, C.; Cortese, J.F.; Guerrero Bravo, J.E.; et al. Novel inhibitors of Plasmodium falciparum dihydroorotate dehydrogenase with anti-malarial activity in the mouse model. J. Biol. Chem. 2010, 285, 33054-33064. [CrossRef] [PubMed]

72. Coteron, J.M.; Marco, M.; Esquivias, J.; Deng, X.; White, K.L.; White, J.; Koltun, M.; El Mazouni, F.; Kokkonda, S.; Katneni, K.; et al. Structure-guided lead optimization of triazolopyrimidine-ring substituents identifies potent Plasmodium falciparum dihydroorotate dehydrogenase inhibitors with clinical candidate potential. J. Med. Chem. 2011, 54, 5540-5561. [CrossRef] [PubMed]

73. Ross, L.S.; Javier Gamo, F.; Lafuente-Monasterio, M.J.; Singh, O.M.; Rowland, P.; Wiegand, R.C.; Wirth, D.F. In vitro resistance selections for Plasmodium falciparum dihydroorotate dehydrogenase inhibitors give mutants with multiple point mutations in the drug-binding site and altered growth. J. Biol. Chem. 2014, 289, 17980-17995. [CrossRef] [PubMed]

74. Arakaki, T.L.; Buckner, F.S.; Gillespie, J.R.; Malmquist, N.A.; Phillips, M.A.; Kalyuzhniy, O.; Luft, J.R.; Detitta, G.T.; Verlinde, C.L.; van Voorhis, W.C.; et al. Characterization of Trypanosoma brucei dihydroorotate dehydrogenase as a possible drug target; structural, kinetic and RNAi studies. Mol. Microbiol. 2008, 68, 37-50. [CrossRef] [PubMed]

75. Pinheiro, M.P.; Iulek, J.; Cristina Nonato, M. Crystal structure of Trypanosoma cruzi dihydroorotate dehydrogenase from Y strain. Biochem. Biophys. Res. Commun. 2008, 369, 812-817. [CrossRef] [PubMed]

76. Inaoka, D.K.; Sakamoto, K.; Shimizu, H.; Shiba, T.; Kurisu, G.; Nara, T.; Aoki, T.; Kita, K.; Harada, S. Structures of Trypanosoma cruzi dihydroorotate dehydrogenase complexed with substrates and products: Atomic resolution insights into mechanisms of dihydroorotate oxidation and fumarate reduction. Biochemistry 2008, 47, 10881-10891. [CrossRef] [PubMed] 
77. Inaoka, D.K.; Shimizu, H.; Sakamoto, K.; Shiba, T.; Kurisu, G.; Nara, T.; Aoki, T.; Harada, S.; Kita, K. Crystal structures of Trypanosoma cruzi dihydroorotate dehydrogenase. Unpublished work, 2008, doi:10.2210/pdb2e68/pdb, doi:10.2210/pdb2e6a/pdb, doi:10.2210/pdb2e6f/pdb, doi:10.2210/pdb2djl/pdb, doi:10.2210/pdb2djx/pdb.

78. Inaoka, D.K.; Iida, M.; Tabuchi, T.; Lee, N.; Matsuoka, S.; Shiba, T.; Sakamoto, K.; Suzuki, S.; Balogun, E.O.; Nara, T.; et al. Structures of Trypanosoma cruzi dihydroorotate dehydrogenase. Unpublished work, 2013, doi:10.2210/pdb3w1a/pdb, doi:10.2210/pdb3w1l/pdb, doi:10.2210/pdb3w1m/pdb, doi:10.2210/pdb3w1n/ pdb, doi:10.2210/pdb3w1p/pdb, doi:10.2210/pdb3w1q/pdb, doi:10.2210/pdb3w1r/pdb, doi:10.2210/ pdb3w1t/pdb, doi:10.2210/pdb3w1ut/pdb, doi:10.2210/pdb3w1x/pdb, doi:10.2210/pdb3w22/pdb, doi:10.2210/pdb3w23/pdb, doi:10.2210/pdb3w2j/pdb, doi:10.2210/pdb3w2k/pdb, doi:10.2210/pdb3w2l/ pdb, doi:10.2210/pdb3w2m/pdb, doi:10.2210/pdb3w2n/pdb, doi:10.2210/pdb3w2u/pdb.

79. Inaoka, D.K.; Iida, M.; Tabuchi, T.; Lee, N.; Matsuoka, S.; Shiba, T.; Sakamoto, K.; Suzuki, S.; Rocha, J.R.; Balogun, E.O.; et al. Structure of Trypanosoma cruzi dihydroorotate dehydrogenase in complex with MII-4-053. Unpublished work, 2014, doi:10.2210/pdb3w3o/pdb.

80. Inaoka, D.K.; Iida, M.; Tabuchi, T.; Lee, N.; Hashimoto, S.; Matsuoka, S.; Kuranaga, T.; Shiba, T.; Sakamoto, K.; Suzuki, S.; et al. Structures of Trypanosoma cruzi dihydroorotate dehydrogenase. Unpublished work, 2014, doi:10.2210/pdb3w6y/pdb, doi:10.2210/pdb3w70/pdb, doi:10.2210/pdb3w71/pdb, doi:10.2210/pdb3w72/ pdb, doi:10.2210/pdb3w73/pdb, doi:10.2210/pdb3w74/pdb, doi:10.2210/pdb3w75/pdb, doi:10.2210/ pdb3w76/pdb, doi:10.2210/pdb3w7c/pdb, doi:10.2210/pdb3w7d/pdb, doi:10.2210/pdb3w7e/pdb, doi:10.2210/pdb3w7g/pdb, doi:10.2210/pdb3w7h/pdb, doi:10.2210/pdb3w7i/pdb, doi:10.2210/pdb3w7j/ pdb, doi:10.2210/pdb3w7k/pdb, doi:10.2210/pdb3w7l/pdb, doi:10.2210/pdb3w7m/pdb, doi:10.2210/ pdb3w7n/pdb, doi:10.2210/pdb3w7o/pdb, doi:10.2210/pdb3w7p/pdb, doi:10.2210/pdb3w7q/pdb, doi:10.2210/pdb4jd4/pdb, doi:10.2210/pdb4jdb/pdb.

81. Inaoka, D.K.; Iida, M.; Tabuchi, T.; Lee, N.; Hashimoto, S.; Matsuoka, S.; Kuranaga, T.; Shiba, T.; Sakamoto, K.; Suzuki, S.; et al. Structures of Trypanosoma cruzi dihydroorotate dehydrogenase. Unpublished work, 2014, doi:10.2210/pdb3w83/pdb, doi:10.2210/pdb3w84/pdb, doi:10.2210/pdb3w85/pdb.

82. Inaoka, D.K.; Hashimoto, S.; Rocha, J.R.; Iida, M.; Tabuchi, T.; Lee, N.; Matsuoka, S.; Kuranaga, T.; Shiba, T.; Balogun, E.O.; et al. Structures of Trypanosoma cruzi dihydroorotate dehydrogenase. Unpublished work, 2014, doi:10.2210/pdb3w86/pdb, doi:10.2210/pdb3w87/pdb, doi:10.2210/pdb3w88/pdb.

83. Bhatt, T.K.; Yogavel, M.; Wydau, S.; Berwal, R.; Sharma, A. Ligand-bound structures provide atomic snapshots for the catalytic mechanism of D-amino acid deacylase. J. Biol. Chem. 2010, 285, 5917-5930. [CrossRef] [PubMed]

84. Yogavel, M.; Khan, S.; Bhatt, T.K.; Sharma, A. Structure of D-tyrosyl-tRNATyr deacylase using home-source $\mathrm{Cu}$ Kalpha and moderate-quality iodide-SAD data: Structural polymorphism and HEPES-bound enzyme states. Acta Crystallogr. D Biol. Crystallogr. 2010, 66, 584-592. [CrossRef] [PubMed]

85. Ahmad, S.; Routh, S.B.; Kamarthapu, V.; Chalissery, J.; Muthukumar, S.; Hussain, T.; Kruparani, S.P.; Deshmukh, M.V.; Sankaranarayanan, R. Mechanism of chiral proofreading during translation of the genetic code. Elife 2013, 2, e01519. [CrossRef] [PubMed]

86. Da Silva Giotto, M.T.; Hannaert, V.; Vertommen, D.; de AS Navarro, M.V.; Rider, M.H.; Michels, P.A.; Garratt, R.C.; Rigden, D.J. The crystal structure of Trypanosoma brucei enolase: Visualisation of the inhibitory metal binding site III and potential as target for selective, irreversible inhibition. J. Mol. Biol. 2003, 331, 653-665. [CrossRef]

87. De AS Navarro, M.V.; Gomes Dias, S.M.; Mello, L.V.; da Silva Giotto, M.T.; Gavalda, S.; Blonski, C.; Garratt, R.C.; Rigden, D.J. Structural flexibility in Trypanosoma brucei enolase revealed by X-ray crystallography and molecular dynamics. FEBS J. 2007, 274, 5077-5089. [CrossRef] [PubMed]

88. Perozzo, R.; Kuo, M.; Sidhu, A.B.; Valiyaveettil, J.T.; Bittman, R.; Jacobs, W.R.; Fidock, D.A.; Sacchettini, J.C. Structural elucidation of the specificity of the antibacterial agent triclosan for malarial enoyl acyl carrier protein reductase. J. Biol. Chem. 2002, 277, 13106-13114. [CrossRef] [PubMed]

89. Pidugu, L.S.; Kapoor, M.; Surolia, N.; Surolia, A.; Suguna, K. Structural basis for the variation in triclosan affinity to enoyl reductases. J. Mol. Biol. 2004, 343, 147-155. [CrossRef] [PubMed] 
90. Freundlich, J.S.; Anderson, J.W.; Sarantakis, D.; Shieh, H.M.; Yu, M.; Valderramos, J.C.; Lucumi, E.; Kuo, M.; Jacobs, W.R.; Fidock, D.A.; et al. Synthesis, biological activity, and X-ray crystal structural analysis of diaryl ether inhibitors of malarial enoyl acyl carrier protein reductase. Part 1: $4^{\prime}$-substituted triclosan derivatives. Bioorg. Med. Chem. Lett. 2005, 15, 5247-5252. [CrossRef] [PubMed]

91. Muench, S.P.; Prigge, S.T.; McLeod, R.; Rafferty, J.B.; Kirisits, M.J.; Roberts, C.W.; Mui, E.J.; Rice, D.W. Studies of Toxoplasma gondii and Plasmodium falciparum enoyl acyl carrier protein reductase and implications for the development of antiparasitic agents. Acta Crystallogr. D Biol. Crystallogr. 2007, 63, 328-338. [CrossRef] [PubMed]

92. Freundlich, J.S.; Wang, F.; Tsai, H.C.; Kuo, M.; Shieh, H.M.; Anderson, J.W.; Nkrumah, L.J.; Valderramos, J.C.; Yu, M.; Kumar, T.R.; et al. X-ray structural analysis of Plasmodium falciparum enoyl acyl carrier protein reductase as a pathway toward the optimization of triclosan antimalarial efficacy. J. Biol. Chem. 2007, 282, 25436-25444. [CrossRef] [PubMed]

93. Maity, K.; Bhargav, S.P.; Sankaran, B.; Surolia, N.; Surolia, A.; Suguna, K. X-ray crystallographic analysis of the complexes of enoyl acyl carrier protein reductase of Plasmodium falciparum with triclosan variants to elucidate the importance of different functional groups in enzyme inhibition. IUBMB Life 2010, 62, 467-476. [PubMed]

94. Belluti, F.; Perozzo, R.; Lauciello, L.; Colizzi, F.; Kostrewa, D.; Bisi, A.; Gobbi, S.; Rampa, A.; Bolognesi, M.L.; Recanatini, M.; et al. Design, synthesis, and biological and crystallographic evaluation of novel inhibitors of Plasmodium falciparum enoyl-ACP-reductase (PfFabI). J. Med. Chem. 2013, 56, 7516-7526. [CrossRef] [PubMed]

95. Wang, S.X.; Pandey, K.C.; Somoza, J.R.; Sijwali, P.S.; Kortemme, T.; Brinen, L.S.; Fletterick, R.J.; Rosenthal, P.J.; McKerrow, J.H. Structural basis for unique mechanisms of folding and hemoglobin binding by a malarial protease. Proc. Natl. Acad. Sci. USA 2006, 103, 11503-11508. [CrossRef] [PubMed]

96. Hogg, T.; Nagarajan, K.; Herzberg, S.; Chen, L.; Shen, X.; Jiang, H.; Wecke, M.; Blohmke, C.; Hilgenfeld, R.; Schmidt, C.L. Structural and functional characterization of Falcipain-2, a hemoglobinase from the malarial parasite Plasmodium falciparum. J. Biol. Chem. 2006, 281, 25425-25437. [CrossRef] [PubMed]

97. Wang, S.X.; Pandey, K.C.; Scharfstein, J.; Whisstock, J.; Huang, R.K.; Jacobelli, J.; Fletterick, R.J.; Rosenthal, P.J.; Abrahamson, M.; Brinen, L.S.; et al. The structure of chagasin in complex with a cysteine protease clarifies the binding mode and evolution of an inhibitor family. Structure 2007, 15, 535-543. [CrossRef] [PubMed]

98. Kerr, I.D.; Lee, J.H.; Pandey, K.C.; Harrison, A.; Sajid, M.; Rosenthal, P.J.; Brinen, L.S. Structures of falcipain-2 and falcipain-3 bound to small molecule inhibitors: Implications for substrate specificity. J. Med. Chem. 2009, 52, 852-857. [CrossRef] [PubMed]

99. Hansen, G.; Heitmann, A.; Witt, T.; Li, H.; Jiang, H.; Shen, X.; Heussler, V.T.; Rennenberg, A.; Hilgenfeld, R. Structural basis for the regulation of cysteine-protease activity by a new class of protease inhibitors in Plasmodium. Structure 2011, 19, 919-929. [CrossRef] [PubMed]

100. Aripirala, S.; Gonzalez-Pacanowska, D.; Oldfield, E.; Kaiser, M.; Amzel, L.M.; Gabelli, S.B. Structural and thermodynamic basis of the inhibition of Leishmania major farnesyl diphosphate synthase by nitrogen-containing bisphosphonates. Acta Crystallogr. D Biol. Crystallogr. 2014, 70, 802-810. [CrossRef] [PubMed]

101. Mao, J.; Mukherjee, S.; Zhang, Y.; Cao, R.; Sanders, J.M.; Song, Y.; Zhang, Y.; Meints, G.A.; Gao, Y.G.; Mukkamala, D.; et al. Solid-state NMR, crystallographic, and computational investigation of bisphosphonates and farnesyl diphosphate synthase-bisphosphonate complexes. J. Am. Chem. Soc. 2006, 128, 14485-14497. [CrossRef] [PubMed]

102. Cao, R.; Chen, C.K.; Guo, R.T.; Wang, A.H.; Oldfield, E. Structures of a potent phenylalkyl bisphosphonate inhibitor bound to farnesyl and geranylgeranyl diphosphate synthases. Proteins 2008, 73, 431-439. [CrossRef] [PubMed]

103. Zhang, Y.; Cao, R.; Yin, F.; Hudock, M.P.; Guo, R.T.; Krysiak, K.; Mukherjee, S.; Gao, Y.G.; Robinson, H.; Song, Y.; et al. Lipophilic bisphosphonates as dual farnesyl/geranylgeranyl diphosphate synthase inhibitors: An X-ray and NMR investigation. J. Am. Chem. Soc. 2009, 131, 5153-5162. [CrossRef] [PubMed]

104. Zhang, Y.; Cao, R.; Leon, A.; Guo, R.T.; Krysiak, K.; Yin, F.; Hudock, M.P.; Mukherjee, S.; Gao, Y.; Robinson, H.; et al. Bisphosphonates: Teaching old drugs with new tricks. Unpublished work, 2007, doi:10.2210/pdb2ogd/pdb. 
105. Gabelli, S.B.; McLellan, J.S.; Montalvetti, A.; Oldfield, E.; Docampo, R.; Amzel, L.M. Structure and mechanism of the farnesyl diphosphate synthase from Trypanosoma cruzi: Implications for drug design. Proteins 2006, 62, 80-88. [CrossRef] [PubMed]

106. Huang, C.H.; Gabelli, S.B.; Oldfield, E.; Amzel, L.M. Binding of nitrogen-containing bisphosphonates (N-BPs) to the Trypanosoma cruzi farnesyl diphosphate synthase homodimer. Proteins 2010, 78, 888-899. [CrossRef] [PubMed]

107. Aripirala, S.; Szajnman, S.H.; Jakoncic, J.; Rodriguez, J.B.; Docampo, R.; Gabelli, S.B.; Amzel, L.M. Design, synthesis, calorimetry, and crystallographic analysis of 2-alkylaminoethyl-1,1-bisphosphonates as inhibitors of Trypanosoma cruzi farnesyl diphosphate synthase. J. Med. Chem. 2012, 55, 6445-6454. [CrossRef] [PubMed]

108. Milani, M.; Balconi, E.; Aliverti, A.; Mastrangelo, E.; Seeber, F.; Bolognesi, M.; Zanetti, G. Ferredoxin-NADP ${ }^{+}$ reductase from Plasmodium falciparum undergoes $\mathrm{NADP}^{+}$-dependent dimerization and inactivation: Functional and crystallographic analysis. J. Mol. Biol. 2007, 367, 501-513. [CrossRef] [PubMed]

109. Harikishore, A.; Niang, M.; Rajan, S.; Preiser, P.R.; Yoon, H.S. Small molecule Plasmodium FKBP35 inhibitor as a potential antimalaria agent. Sci. Rep. 2013, 3, 2501. [CrossRef] [PubMed]

110. Chudzik, D.M.; Michels, P.A.; de Walque, S.; Hol, W.G. Structures of type 2 peroxisomal targeting signals in two trypanosomatid aldolases. J. Mol. Biol. 2000, 300, 697-707. [CrossRef] [PubMed]

111. Lafrance-Vanasse, J.; Sygusch, J. Carboxy-terminus recruitment induced by substrate binding in eukaryotic fructose bis-phosphate aldolases. Biochemistry 2007, 46, 9533-9540. [CrossRef] [PubMed]

112. Kim, H.; Certa, U.; Döbeli, H.; Jakob, P.; Hol, W.G. Crystal structure of fructose-1,6-bisphosphate aldolase from the human malaria parasite Plasmodium falciparum. Biochemistry 1998, 37, 4388-4396. [CrossRef] [PubMed]

113. Zocher, K.; Fritz-Wolf, K.; Kehr, S.; Fischer, M.; Rahlfs, S.; Becker, K. Biochemical and structural characterization of Plasmodium falciparum glutamate dehydrogenase 2. Mol. Biochem. Parasitol. 2012, 183, 52-62. [CrossRef] [PubMed]

114. Patel, S.; Hussain, S.; Harris, R.; Sardiwal, S.; Kelly, J.M.; Wilkinson, S.R.; Driscoll, P.C.; Djordjevic, S. Structural insights into the catalytic mechanism of Trypanosoma cruzi GPXI (glutathione peroxidase-like enzyme I). Biochem. J. 2010, 425, 513-522. [CrossRef] [PubMed]

115. Sarma, G.N.; Savvides, S.N.; Becker, K.; Schirmer, M.; Schirmer, R.H.; Karplus, P.A. Glutathione reductase of the malarial parasite Plasmodium falciparum: Crystal structure and inhibitor development. J. Mol. Biol. 2003, 328, 893-907. [CrossRef]

116. Fritz-Wolf, K.; Becker, A.; Rahlfs, S.; Harwaldt, P.; Schirmer, R.H.; Kabsch, W.; Becker, K. X-ray structure of glutathione $S$-transferase from the malarial parasite Plasmodium falciparum. Proc. Natl. Acad. Sci. USA 2003, 100, 13821-13826. [CrossRef] [PubMed]

117. Perbandt, M.; Burmeister, C.; Walter, R.D.; Betzel, C.; Liebau, E. Native and inhibited structure of a Mu class-related glutathione S-transferase from Plasmodium falciparum. J. Biol. Chem. 2004, 279, 1336-1342. [CrossRef] [PubMed]

118. Hiller, N.; Fritz-Wolf, K.; Deponte, M.; Wende, W.; Zimmermann, H.; Becker, K. Plasmodium falciparum glutathione $S$-transferase-Structural and mechanistic studies on ligand binding and enzyme inhibition. Protein Sci. 2006, 15, 281-289. [CrossRef] [PubMed]

119. Kim, H.; Feil, I.K.; Verlinde, C.L.; Petra, P.H.; Hol, W.G. Crystal structure of glycosomal glyceraldehyde-3-phosphate dehydrogenase from Leishmania mexicana: Implications for structure-based drug design and a new position for the inorganic phosphate binding site. Biochemistry 1995, 34, 14975-14986. [CrossRef] [PubMed]

120. Kim, H.; Hol, W.G. Crystal structure of Leishmania mexicana glycosomal glyceraldehyde-3-phosphate dehydrogenase in a new crystal form confirms the putative physiological active site structure. J. Mol. Biol. 1998, 278, 5-11. [CrossRef] [PubMed]

121. Aronov, A.M.; Suresh, S.; Buckner, F.S.; van Voorhis, W.C.; Verlinde, C.L.; Opperdoes, F.R.; Hol, W.G.; Gelb, M.H. Structure-based design of submicromolar, biologically active inhibitors of trypanosomatid glyceraldehyde-3-phosphate dehydrogenase. Proc. Natl. Acad. Sci. USA 1999, 96, 4273-4278. [CrossRef] [PubMed]

122. Satchell, J.F.; Malby, R.L.; Luo, C.S.; Adisa, A.; Alpyurek, A.E.; Klonis, N.; Smith, B.J.; Tilley, L.; Colman, P.M. Structure of glyceraldehyde-3-phosphate dehydrogenase from Plasmodium falciparum. Acta Crystallogr. D Biol. Crystallogr. 2005, 61, 1213-1221. [CrossRef] [PubMed] 
123. Robien, M.A.; Bosch, J.; Buckner, F.S.; van Voorhis, W.C.; Worthey, E.A.; Myler, P.; Mehlin, C.; Boni, E.E.; Kalyuzhniy, O.; Anderson, L.; et al. Crystal structure of glyceraldehyde-3-phosphate dehydrogenase from Plasmodium falciparum at $2.25 \AA$ resolution reveals intriguing extra electron density in the active site. Proteins 2006, 62, 570-577. [CrossRef] [PubMed]

124. Vellieux, F.M.; Hajdu, J.; Verlinde, C.L.; Groendijk, H.; Read, R.J.; Greenhough, T.J.; Campbell, J.W.; Kalk, K.H.; Littlechild, J.A.; Watson, H.C.; et al. Structure of glycosomal glyceraldehyde-3-phosphate dehydrogenase from Trypanosoma brucei determined from Laue data. Proc. Natl. Acad. Sci. USA 1993, 90, 2355-2359. [CrossRef] [PubMed]

125. Seattle Structural Genomics Center for Infectious Disease; Abendroth, J.; Lorimer, D.; Edwards, T.E. Structure of a glycosomal glyceraldehyde 3-phosphate dehydrogenase from Trypanosoma brucei. Unpublished work, 2014, doi:10.2210/pdb4p8r/pdb.

126. Pavão, F.; Castilho, M.S.; Pupo, M.T.; Dias, R.L.; Correa, A.G.; Fernandes, J.B.; da Silva, M.F.; Mafezoli, J.; Vieira, P.C.; Oliva, G. Structure of Trypanosoma cruzi glycosomal glyceraldehyde-3-phosphate dehydrogenase complexed with chalepin, a natural product inhibitor, at 1.95 Å resolution. FEBS Lett. 2002, 520, 13-17. [CrossRef]

127. Castilho, M.S.; Pavão, F.; Oliva, G.; Ladame, S.; Willson, M.; Périé, J. Evidence for the two phosphate binding sites of an analogue of the thioacyl intermediate for the Trypanosoma cruzi glyceraldehyde-3-phosphate dehydrogenase-catalyzed reaction, from its crystal structure. Biochemistry 2003, 42, 7143-7151. [CrossRef] [PubMed]

128. Ladame, S.; Castilho, M.S.; Silva, C.H.; Denier, C.; Hannaert, V.; Périé, J.; Oliva, G.; Willson, M. Crystal structure of Trypanosoma cruzi glyceraldehyde-3-phosphate dehydrogenase complexed with an analogue of 1,3-bisphospho-D-glyceric acid. Eur. J. Biochem. 2003, 270, 4574-4586. [CrossRef] [PubMed]

129. Balliano, T.L.; Guido, R.V.C.; Andricopulo, A.D.; Oliva, G. Structure of glycosomal glyceraldehyde-3phosphate dehydrogenase from Trypanosoma cruzi in complex with the irreversible iodoacetamide inhibitor. Unpublished work, 2009, doi:10.2210/pdb3ids/pdb.

130. Suresh, S.; Turley, S.; Opperdoes, F.R.; Michels, P.A.; Hol, W.G. A potential target enzyme for trypanocidal drugs revealed by the crystal structure of NAD-dependent glycerol-3-phosphate dehydrogenase from Leishmania mexicana. Structure 2000, 8, 541-552. [CrossRef]

131. Choe, J.; Suresh, S.; Wisedchaisri, G.; Kennedy, K.J.; Gelb, M.H.; Hol, W.G. Anomalous differences of light elements in determining precise binding modes of ligands to glycerol-3-phosphate dehydrogenase. Chem. Biol. 2002, 9, 1189-1197. [CrossRef]

132. Choe, J.; Guerra, D.; Michels, P.A.; Hol, W.G. Leishmania mexicana glycerol-3-phosphate dehydrogenase showed conformational changes upon binding a bi-substrate adduct. J. Mol. Biol. 2003, 329, 335-349. [CrossRef]

133. Ariza, A.; Vickers, T.J.; Greig, N.; Armour, K.A.; Dixon, M.J.; Eggleston, I.M.; Fairlamb, A.H.; Bond, C.S. Specificity of the trypanothione-dependent Leishmania major glyoxalase I: Structure and biochemical comparison with the human enzyme. Mol. Microbiol. 2006, 59, 1239-1248. [CrossRef] [PubMed]

134. Silva, M.S.; Barata, L.; Ferreira, A.E.; Romão, S.; Tomás, A.M.; Freire, A.P.; Cordeiro, C. Catalysis and structural properties of Leishmania infantum glyoxalase II: Trypanothione specificity and phylogeny. Biochemistry 2008, 47, 195-204. [CrossRef] [PubMed]

135. Wernimont, A.K.; Dong, A.; Hills, T.; Amani, M.; Perieteanu, A.; Lin, Y.H.; Loppnau, P.; Arrowsmith, C.H.; Edwards, A.M.; Bountra, C.; et al. Crystal Structure of PF10_0123, a GMP synthetase from Plasmodium falciparum. Unpublished work, 2011, doi:10.2210/pdb3uow/pdb.

136. Vedadi, M.; Lew, J.; Artz, J.; Amani, M.; Zhao, Y.; Dong, A.; Wasney, G.A.; Gao, M.; Hills, T.; Brokx, S.; et al. Genome-scale protein expression and structural biology of Plasmodium falciparum and related Apicomplexan organisms. Mol. Biochem. Parasitol. 2007, 151, 100-110. [CrossRef] [PubMed]

137. Wernimont, A.K.; Tempel, W.; Lin, Y.H.; Hutchinson, A.; Mackenzie, F.; Fairlamb, A.; Kozieradzki, I.; Cossar, D.; Zhao, Y.; Schapira, M.; et al. Crystal structure of the amino-terminal domain of HSP90 from Leishmania major, LmjF33.0312:M1-K213. Unpublished work, 2009, doi:10.2210/pdb3h80/pdb.

138. Wernimont, A.K.; Tempel, W.; Lin, Y.H.; Hutchinson, A.; MacKenzie, F.; Fairlamb, A.; Cossar, D.; Zhao, Y.; Schapira, M.; Arrowsmith, C.H.; et al. Crystal structure of the amino-terminal domain of HSP90 from Leishmania major, LMJF33.0312:M1-K213. Unpublished work, 2011, doi:10.2210/pdb3q5j/pdb, doi:10.2210/pdb3q5k/pdb, doi:10.2210/pdb3q5l/pdb. 
139. Hills, T.; Pizarro, J.C.; Wernimont, A.K.; Ferguson, M.A.J.; Hui, R. Crystal structure of the N-terminal domain of Hsp90 from Leishmania major (LmjF33.0312) in complex with ADP. Unpublished work, 2012, doi:10.2210/pdb3u67/pdb.

140. Merritt, E.A.; Arakaki, T.L.; Gillespie, J.R.; Larson, E.T.; Kelley, A.; Mueller, N.; Napuli, A.J.; Kim, J.; Zhang, L.; Verlinde, C.L.; et al. Crystal structures of trypanosomal histidyl-tRNA synthetase illuminate differences between eukaryotic and prokaryotic homologs. J. Mol. Biol. 2010, 397, 481-494. [CrossRef] [PubMed]

141. Bhaumik, P.; Xiao, H.; Parr, C.L.; Kiso, Y.; Gustchina, A.; Yada, R.Y.; Wlodawer, A. Crystal structures of the histo-aspartic protease (HAP) from Plasmodium falciparum. J. Mol. Biol. 2009, 388, 520-540. [CrossRef] [PubMed]

142. Maity, K.; Venkata, B.S.; Kapoor, N.; Surolia, N.; Surolia, A.; Suguna, K. Structural basis for the functional and inhibitory mechanisms of $\beta$-hydroxyacyl-acyl carrier protein dehydratase (FabZ) of Plasmodium falciparum. J. Struct. Biol. 2011, 176, 238-249. [CrossRef] [PubMed]

143. Rekittke, I.; Olkhova, E.; Wiesner, J.; Demmer, U.; Warkentin, E.; Jomaa, H.; Ermler, U. Structure of the (E)-4-hydroxy-3-methyl-but-2-enyl-diphosphate reductase from Plasmodium falciparum. FEBS Lett. 2013, 587, 3968-3972. [CrossRef] [PubMed]

144. Shi, W.; Li, C.M.; Tyler, P.C.; Furneaux, R.H.; Cahill, S.M.; Girvin, M.E.; Grubmeyer, C.; Schramm, V.L.; Almo, S.C. The $2.0 \AA$ structure of malarial purine phosphoribosyltransferase in complex with a transition-state analogue inhibitor. Biochemistry 1999, 38, 9872-9880. [CrossRef] [PubMed]

145. Focia, P.J.; Craig, S.P.; Eakin, A.E. Approaching the transition state in the crystal structure of a phosphoribosyltransferase. Biochemistry 1998, 37, 17120-17127. [CrossRef] [PubMed]

146. Canyuk, B.; Medrano, F.J.; Wenck, M.A.; Focia, P.J.; Eakin, A.E.; Craig, S.P. Interactions at the dimer interface influence the relative efficiencies for purine nucleotide synthesis and pyrophosphorolysis in a phosphoribosyltransferase. J. Mol. Biol. 2004, 335, 905-921. [CrossRef] [PubMed]

147. Dunn, C.R.; Banfield, M.J.; Barker, J.J.; Higham, C.W.; Moreton, K.M.; Turgut-Balik, D.; Brady, R.L.; Holbrook, J.J. The structure of lactate dehydrogenase from Plasmodium falciparum reveals a new target for anti-malarial design. Nat. Struct. Biol. 1996, 3, 912-915. [CrossRef] [PubMed]

148. Read, J.A.; Wilkinson, K.W.; Tranter, R.; Sessions, R.B.; Brady, R.L. Chloroquine binds in the cofactor binding site of Plasmodium falciparum lactate dehydrogenase. J. Biol. Chem. 1999, 274, 10213-10218. [CrossRef] [PubMed]

149. Cameron, A.; Read, J.; Tranter, R.; Winter, V.J.; Sessions, R.B.; Brady, R.L.; Vivas, L.; Easton, A.; Kendrick, H.; Croft, S.L.; et al. Identification and activity of a series of azole-based compounds with lactate dehydrogenase-directed anti-malarial activity. J. Biol. Chem. 2004, 279, 31429-31439. [CrossRef] [PubMed]

150. Conners, R.; Schambach, F.; Read, J.; Cameron, A.; Sessions, R.B.; Vivas, L.; Easton, A.; Croft, S.L.; Brady, R.L. Mapping the binding site for gossypol-like inhibitors of Plasmodium falciparum lactate dehydrogenase. Mol. Biochem. Parasitol. 2005, 142, 137-148. [CrossRef] [PubMed]

151. Chaikuad, A.; Fairweather, V.; Conners, R.; Joseph-Horne, T.; Turgut-Balik, D.; Brady, R.L. Structure of lactate dehydrogenase from Plasmodium vivax: Complexes with NADH and APADH. Biochemistry 2005, 44, 16221-16228. [CrossRef] [PubMed]

152. Birkinshaw, R.W.; Brady, R.L. The crystal structure of Plasmodium falciparum L-lactate dehydrogenase in complex with a novel bicine ligand. Unpublished work, 2012, doi:10.2210/pdb4b7u/pdb.

153. Werner, C.; Krauth-Siegel, R.L.; Stubbs, M.T.; Klebe, G. Crystal structure of lipoamide dehydrogenase from Trypanosoma cruzi: A putative target for the design of new drugs against Chagas disease. Unpublished work, 2008, doi:10.2210/pdb2qae/pdb.

154. Khan, S.; Garg, A.; Camacho, N.; van Rooyen, J.; Kumar Pole, A.; Belrhali, H.; Ribas de Pouplana, L.; Sharma, V.; Sharma, A. Structural analysis of malaria-parasite lysyl-tRNA synthetase provides a platform for drug development. Acta Crystallogr. D Biol. Crystallogr. 2013, 69, 785-795. [CrossRef] [PubMed]

155. Kannan Sivaraman, K.; Paiardini, A.; Sieńczyk, M.; Ruggeri, C.; Oellig, C.A.; Dalton, J.P.; Scammells, P.J.; Drag, M.; McGowan, S. Synthesis and structure-activity relationships of phosphonic arginine mimetics as inhibitors of the M1 and M17 aminopeptidases from Plasmodium falciparum. J. Med. Chem. 2013, 56, 5213-5217. [CrossRef] [PubMed] 
156. McGowan, S.; Oellig, C.A.; Birru, W.A.; Caradoc-Davies, T.T.; Stack, C.M.; Lowther, J.; Skinner-Adams, T.; Mucha, A.; Kafarski, P.; Grembecka, J.; et al. Structure of the Plasmodium falciparum M17 aminopeptidase and significance for the design of drugs targeting the neutral exopeptidases. Proc. Natl. Acad. Sci. USA 2010, 107, 2449-2454. [CrossRef] [PubMed]

157. Harbut, M.B.; Velmourougane, G.; Dalal, S.; Reiss, G.; Whisstock, J.C.; Onder, O.; Brisson, D.; McGowan, S.; Klemba, M.; Greenbaum, D.C. Bestatin-based chemical biology strategy reveals distinct roles for malaria M1and M17-family aminopeptidases. Proc. Natl. Acad. Sci. USA 2011, 108, E526-E334. [CrossRef] [PubMed]

158. Sivaraman, K.K.; Oellig, C.A.; Huynh, K.; Atkinson, S.C.; Poreba, M.; Perugini, M.A.; Trenholme, K.R.; Gardiner, D.L.; Salvesen, G.; Drag, M.; et al. X-ray crystal structure and specificity of the Plasmodium falciparum malaria aminopeptidase PfM18AAP. J. Mol. Biol. 2012, 422, 495-507. [CrossRef] [PubMed]

159. Pereira, P.J.; Vega, M.C.; González-Rey, E.; Fernández-Carazo, R.; Macedo-Ribeiro, S.; Gomis-Rüth, F.X.; González, A.; Coll, M. Trypanosoma cruzi macrophage infectivity potentiator has a rotamase core and a highly exposed alpha-helix. EMBO Rep. 2002, 3, 88-94. [CrossRef] [PubMed]

160. McLuskey, K.; Rudolf, J.; Proto, W.R.; Isaacs, N.W.; Coombs, G.H.; Moss, C.X.; Mottram, J.C. Crystal structure of a Trypanosoma brucei metacaspase. Proc. Natl. Acad. Sci. USA 2012, 109, 7469-7474. [CrossRef] [PubMed]

161. Niemirowicz, G.; Fernández, D.; Solà, M.; Cazzulo, J.J.; Avilés, F.X.; Gomis-Rüth, F.X. The molecular analysis of Trypanosoma cruzi metallocarboxypeptidase 1 provides insight into fold and substrate specificity. Mol. Microbiol. 2008, 70, 853-866. [PubMed]

162. Wernimont, A.K.; Artz, J.D.; Crombet, L.; Lew, J.; Weadge, J.; Arrowsmith, C.H.; Edwards, A.M.; Weigelt, J.; Bountra, C.; Hui, R.; et al. Crystal structure of methionine aminopeptidase $1 \mathrm{~b}$ from Plasmodium falciparum, PF10_0150. Unpublished work, 2011, doi:10.2210/pdb3s6b/pdb.

163. Larson, E.T.; Kim, J.E.; Zucker, F.H.; Kelley, A.; Mueller, N.; Napuli, A.J.; Verlinde, C.L.; Fan, E.; Buckner, F.S.; van Voorhis, W.C.; et al. Structure of Leishmania major methionyl-tRNA synthetase in complex with intermediate products methionyladenylate and pyrophosphate. Biochimie 2011, 93, 570-582. [CrossRef] [PubMed]

164. Koh, C.Y.; Kim, J.E.; Shibata, S.; Ranade, R.M.; Yu, M.; Liu, J.; Gillespie, J.R.; Buckner, F.S.; Verlinde, C.L.; Fan, E.; et al. Distinct states of methionyl-tRNA synthetase indicate inhibitor binding by conformational selection. Structure 2012, 20, 1681-1691. [CrossRef] [PubMed]

165. Koh, C.Y.; Kim, J.E.; Wetzel, A.B.; de van der Schueren, W.J.; Shibata, S.; Ranade, R.M.; Liu, J.; Zhang, Z.; Gillespie, J.R.; Buckner, F.S.; et al. Structures of Trypanosoma brucei methionyl-tRNA synthetase with urea-based inhibitors provide guidance for drug design against sleeping sickness. PLoS Negl. Trop. Dis. 2014, 8, e2775. [CrossRef] [PubMed]

166. Horjales, S.; Schmidt-Arras, D.; Limardo, R.R.; Leclercq, O.; Obal, G.; Prina, E.; Turjanski, A.G.; Späth, G.F.; Buschiazzo, A. The crystal structure of the MAP kinase LmaMPK10 from Leishmania major reveals parasite-specific features and regulatory mechanisms. Structure 2012, 20, 1649-1660. [CrossRef] [PubMed]

167. Eadsforth, T.C.; Cameron, S.; Hunter, W.N. The crystal structure of Leishmania major $\mathrm{N}^{5}, \mathrm{~N}^{10}$ methylenetetrahydrofolate dehydrogenase/cyclohydrolase and assessment of a potential drug target. Mol. Biochem. Parasitol. 2012, 181, 178-185. [CrossRef] [PubMed]

168. Gazanion, E.; Garcia, D.; Silvestre, R.; Gérard, C.; Guichou, J.F.; Labesse, G.; Seveno, M.; Cordeiro-Da-Silva, A.; Ouaissi, A.; Sereno, D.; et al. The Leishmania nicotinamidase is essential for $\mathrm{NAD}^{+}$production and parasite proliferation. Mol. Microbiol. 2011, 82, 21-38. [CrossRef] [PubMed]

169. Brannigan, J.A.; Smith, B.A.; Yu, Z.; Brzozowski, A.M.; Hodgkinson, M.R.; Maroof, A.; Price, H.P.; Meier, F.; Leatherbarrow, R.J.; Tate, E.W.; et al. N-myristoyltransferase from Leishmania donovani: Structural and functional characterisation of a potential drug target for visceral leishmaniasis. J. Mol. Biol. 2010, 396, 985-999. [CrossRef] [PubMed]

170. Frearson, J.A.; Brand, S.; McElroy, S.P.; Cleghorn, L.A.; Smid, O.; Stojanovski, L.; Price, H.P.; Guther, M.L.; Torrie, L.S.; Robinson, D.A.; et al. $N$-myristoyltransferase inhibitors as new leads to treat sleeping sickness. Nature 2010, 464, 728-732. [CrossRef] [PubMed]

171. Brand, S.; Cleghorn, L.A.; McElroy, S.P.; Robinson, D.A.; Smith, V.C.; Hallyburton, I.; Harrison, J.R.; Norcross, N.R.; Spinks, D.; Bayliss, T.; et al. Discovery of a novel class of orally active trypanocidal N-myristoyltransferase inhibitors. J. Med. Chem. 2012, 55, 140-152. [CrossRef] [PubMed] 
172. Bosch, J.; Robien, M.A.; Mehlin, C.; Boni, E.; Riechers, A.; Buckner, F.S.; van Voorhis, W.C.; Myler, P.J.; Worthey, E.A.; DeTitta, G.; et al. Using fragment cocktail crystallography to assist inhibitor design of Trypanosoma brucei nucleoside 2-deoxyribosyltransferase. J. Med. Chem. 2006, 49, 5939-5946. [CrossRef] [PubMed]

173. Souza, T.A.; Trindade, D.M.; Tonoli, C.C.; Santos, C.R.; Ward, R.J.; Arni, R.K.; Oliveira, A.H.; Murakami, M.T. Molecular adaptability of nucleoside diphosphate kinase b from trypanosomatid parasites: Stability, oligomerization and structural determinants of nucleotide binding. Mol. Biosyst. 2011, 7, 2189-2195. [CrossRef] [PubMed]

174. Gardberg, A.S.; Edwards, T.E.; Seattle Structural Genomics Center for Infectious Disease. Crystal structure of nucleoside diphosphate kinase B from Trypanosoma brucei. Unpublished work, 2012, doi:10.2210/pdb4fkx/pdb, doi:10.2210/pdb4fky/pdb.

175. Seattle Structural Genomics Center for Infectious Disease; Gardberg, A.S.; Edwards, T.E.; Staker, B.; Stewart, L. Crystal structure of nucleoside diphosphate kinase B from Trypanosoma brucei. Unpublished work, 2012, doi:10.2210/pdb4f4a/pdb, doi:10.2210/pdb4f36/pdb.

176. Shi, W.; Schramm, V.L.; Almo, S.C. Nucleoside hydrolase from Leishmania major. Cloning, expression, catalytic properties, transition state inhibitors, and the 2.5- $\AA$ crystal structure. J. Biol. Chem. 1999, 274, 21114-21120. [CrossRef] [PubMed]

177. Giannese, F.; Berg, M.; van der Veken, P.; Castagna, V.; Tornaghi, P.; Augustyns, K.; Degano, M. Structures of purine nucleosidase from Trypanosoma brucei bound to isozyme-specific trypanocidals and a novel metalorganic inhibitor. Acta Crystallogr. D Biol. Crystallogr. 2013, 69, 1553-1566. [CrossRef] [PubMed]

178. Vandemeulebrouke, A.; Minici, C.; Bruno, I.; Muzzolini, L.; Tornaghi, P.; Parkin, D.W.; Versées, W.; Steyaert, J.; Degano, M. Structure and mechanism of the 6-oxopurine nucleosidase from Trypanosoma brucei brucei. Biochemistry 2010, 49, 8999-9010. [CrossRef] [PubMed]

179. Gill, J.; Yogavel, M.; Kumar, A.; Belrhali, H.; Jain, S.K.; Rug, M.; Brown, M.; Maier, A.G.; Sharma, A. Crystal structure of malaria parasite nucleosome assembly protein: Distinct modes of protein localization and histone recognition. J. Biol. Chem. 2009, 284, 10076-10087. [CrossRef] [PubMed]

180. Yogavel, M.; Gill, J.; Sharma, A. Iodide-SAD, SIR and SIRAS phasing for structure solution of a nucleosome assembly protein. Acta Crystallogr. D Biol. Crystallogr. 2009, 65, 618-622. [CrossRef] [PubMed]

181. Okamoto, N.; Yamaguchi, K.; Mizohata, E.; Tokuoka, K.; Uchiyama, N.; Sugiyama, S.; Matsumura, H.; Inaka, K.; Urade, Y.; Inoue, T. Structural insight into the stereoselective production of PGF2 $\alpha$ by Old Yellow Enzyme from Trypanosoma cruzi. J. Biochem. 2011, 150, 563-568. [CrossRef] [PubMed]

182. Murakami, M.T.; Rodrigues, N.C.; Gava, L.M.; Canduri, F.; Oliva, G.; Barbosa, L.R.S.; Borgers, J.C. High resolution crystal structure and in solution studies of the old yellow enzyme from Trypanosoma cruzi: Insights into oligomerization, enzyme dynamics and specificity. Unpublished work, 2013, doi:10.2210/pdb4e2b/pdb, doi: $10.2210 / \mathrm{pdb} 4 \mathrm{e} 2 \mathrm{~d} / \mathrm{pdb}$.

183. McLuskey, K.; Paterson, N.G.; Bland, N.D.; Isaacs, N.W.; Mottram, J.C. Crystal structure of Leishmania major oligopeptidase B gives insight into the enzymatic properties of a trypanosomatid virulence factor. J. Biol. Chem. 2010, 285, 39249-39259. [CrossRef] [PubMed]

184. Canning, P.; Rea, D.; Morty, R.E.; Fülöp, V. Crystal structures of Trypanosoma brucei oligopeptidase B broaden the paradigm of catalytic regulation in prolyl oligopeptidase family enzymes. PLoS ONE 2013, 8, e79349. [CrossRef] [PubMed]

185. Grishin, N.V.; Osterman, A.L.; Brooks, H.B.; Phillips, M.A.; Goldsmith, E.J. X-ray structure of ornithine decarboxylase from Trypanosoma brucei: The native structure and the structure in complex with alpha-difluoromethylornithine. Biochemistry 1999, 38, 15174-15184. [CrossRef] [PubMed]

186. Jackson, L.K.; Brooks, H.B.; Osterman, A.L.; Goldsmith, E.J.; Phillips, M.A. Altering the reaction specificity of eukaryotic ornithine decarboxylase. Biochemistry 2000, 39, 11247-11257. [CrossRef] [PubMed]

187. Jackson, L.K.; Goldsmith, E.J.; Phillips, M.A. X-ray structure determination of Trypanosoma brucei ornithine decarboxylase bound to D-ornithine and to G418: Insights into substrate binding and ODC conformational flexibility. J. Biol. Chem. 2003, 278, 22037-22043. [CrossRef] [PubMed]

188. Jortzik, E.; Fritz-Wolf, K.; Sturm, N.; Hipp, M.; Rahlfs, S.; Becker, K. Redox regulation of Plasmodium falciparum ornithine $\delta$-aminotransferase. J. Mol. Biol. 2010, 402, 445-459. [CrossRef] [PubMed] 
189. French, J.B.; Yates, P.A.; Soysa, D.R.; Boitz, J.M.; Carter, N.S.; Chang, B.; Ullman, B.; Ealick, S.E. The Leishmania donovani UMP synthase is essential for promastigote viability and has an unual tetrameric structure that exhibits substrate-controlled oligomerization. J. Biol. Chem. 2011, 286, 20930-20941. [CrossRef] [PubMed]

190. Bello, A.M.; Poduch, E.; Liu, Y.; Wei, L.; Crandall, I.; Wang, X.; Dyanand, C.; Kain, K.C.; Pai, E.F.; Kotra, L.P. Structure-activity relationships of C6-uridine derivatives targeting plasmodia orotidine monophosphate decarboxylase. J. Med. Chem. 2008, 51, 439-448. [CrossRef] [PubMed]

191. Langley, D.B.; Shojaei, M.; Chan, C.; Lok, H.C.; Mackay, J.P.; Traut, T.W.; Guss, J.M.; Christopherson, R.I. Structure and inhibition of orotidine $5^{\prime}$-monophosphate decarboxylase from Plasmodium falciparum. Biochemistry 2008, 47, 3842-3854. [CrossRef] [PubMed]

192. Tokuoka, K.; Kusakari, Y.; Krungkrai, S.R.; Matsumura, H.; Kai, Y.; Krungkrai, J.; Horii, T.; Inoue, T. Structural basis for the decarboxylation of orotidine 5'-monophosphate (OMP) by Plasmodium falciparum OMP decarboxylase. J. Biochem. 2008, 143, 69-78. [CrossRef] [PubMed]

193. Bello, A.M.; Konforte, D.; Poduch, E.; Furlonger, C.; Wei, L.; Liu, Y.; Lewis, M.; Pai, E.F.; Paige, C.J.; Kotra, L.P. Structure-activity relationships of orotidine-5'-monophosphate decarboxylase inhibitors as anticancer agents. J. Med. Chem. 2009, 52, 1648-1658. [CrossRef] [PubMed]

194. Takashima, Y.; Mizohata, E.; Krungkrai, S.R.; Fukunishi, Y.; Kinoshita, T.; Sakata, T.; Matsumura, H.; Krungkrai, J.; Horii, T.; Inoue, T. The in silico screening and X-ray structure analysis of the inhibitor complex of Plasmodium falciparum orotidine 5'-monophosphate decarboxylase. J. Biochem. 2012, 152, $133-138$. [CrossRef] [PubMed]

195. Liu, Y.; Lau, W.; Lew, J.; Amani, M.; Hui, R.; Pai, E.F. Crystal structure of orotidine 5'-phosphate decarboxylase from Plasmodium falciparum. Unpublished work, 2005, doi:10.2210/pdb2f84/pdb.

196. Caruthers, J.M.; Robein, M.; Zucker, F.; Mehlin, C.; Luft, J.; Boni, E.; Lauricella, A.; Merritt, E.A.; Hol, W.G.J. Crystal structure of an orotidine-5' $5^{\prime}$-monophosphate decarboxylase homolog from P. falciparum. Unpublished work, 2005, doi:10.2210/pdb2f84/pdb.

197. Liu, Y.; Kotra, L.P.; Pai, E.F. Crystal structure of Plasmodium falciparum orotidine 5'-monophosphate decarboxylase. Unpublished work, 2011, doi:10.2210/pdb3mwa/pdb, doi:10.2210/pdb3n2m/pdb, doi:10.2210/pdb3n34/pdb, doi:10.2210/pdb3n3m/pdb.

198. Wickramasinghe, S.R.; Inglis, K.A.; Urch, J.E.; Müller, S.; van Aalten, D.M.; Fairlamb, A.H. Kinetic, inhibition and structural studies on 3-oxoacyl-ACP reductase from Plasmodium falciparum, a key enzyme in fatty acid biosynthesis. Biochem. J. 2006, 393, 447-557. [CrossRef] [PubMed]

199. Kumar, A.; Nguyen, K.T.; Srivathsan, S.; Ornstein, B.; Turley, S.; Hirsh, I.; Pei, D.; Hol, W.G. Crystals of peptide deformylase from Plasmodium falciparum reveal critical characteristics of the active site for drug design. Structure 2002, 10, 357-367. [CrossRef]

200. Robien, M.A.; Nguyen, K.T.; Kumar, A.; Hirsh, I.; Turley, S.; Pei, D.; Hol, W.G. An improved crystal form of Plasmodium falciparum peptide deformylase. Protein Sci. 2004, 13, 1155-1163. [CrossRef] [PubMed]

201. Sampathkumar, P.; Roach, C.; Michels, P.A.; Hol, W.G. Structural insights into the recognition of peroxisomal targeting signal 1 by Trypanosoma brucei peroxin 5. J. Mol. Biol. 2008, 381, 867-880. [CrossRef] [PubMed]

202. Lee, S.G.; Kim, Y.; Alpert, T.D.; Nagata, A.; Jez, J.M. Structure and reaction mechanism of phosphoethanolamine methyltransferase from the malaria parasite Plasmodium falciparum: An antiparasitic drug target. J. Biol. Chem. 2012, 287, 1426-1434. [CrossRef] [PubMed]

203. Wang, H.; Yan, Z.; Geng, J.; Kunz, S.; Seebeck, T.; Ke, H. Crystal structure of the Leishmania major phosphodiesterase LmjPDEB1 and insight into the design of the parasite-selective inhibitors. Mol. Microbiol. 2007, 66, 1029-1038. [CrossRef] [PubMed]

204. Jansen, C.; Wang, H.; Kooistra, A.J.; de Graaf, C.; Orrling, K.M.; Tenor, H.; Seebeck, T.; Bailey, D.; de Esch, I.J.; $\mathrm{Ke}, \mathrm{H}$; ; et al. Discovery of novel Trypanosoma brucei phosphodiesterase B1 inhibitors by virtual screening against the unliganded TbrPDEB1 crystal structure. J. Med. Chem. 2013, 56, 2087-2096. [CrossRef] [PubMed]

205. Wang, H.; Kunz, S.; Chen, G.; Seebeck, T.; Wan, Y.; Robinson, H.; Martinelli, S.; Ke, H. Biological and structural characterization of Trypanosoma cruzi phosphodiesterase $\mathrm{C}$ and implications for design of parasite selective inhibitors. J. Biol. Chem. 2012, 287, 11788-11797. [CrossRef] [PubMed]

206. Wang, H.; Kunz, S.; Chen, G.; Seebeck, T.; Wan, Y.; Robinson, H.; Martinelli, S.; Ke, H. TcrPDEC1 catalytic domain in complex with inhibitor wyq16. Unpublished work, 2012, doi:10.2210/pdb3v94/pdb. 
207. Trapani, S.; Linss, J.; Goldenberg, S.; Fischer, H.; Craievich, A.F.; Oliva, G. Crystal structure of the dimeric phosphoenolpyruvate carboxykinase (PEPCK) from Trypanosoma cruzi at 2 A resolution. J. Mol. Biol. 2001, 313, 1059-1072. [CrossRef] [PubMed]

208. McNae, I.W.; Martinez-Oyanedel, J.; Keillor, J.W.; Michels, P.A.; Fothergill-Gilmore, L.A.; Walkinshaw, M.D. The crystal structure of ATP-bound phosphofructokinase from Trypanosoma brucei reveals conformational transitions different from those of other phosphofructokinases. J. Mol. Biol. 2009, 385, 1519-1533. [CrossRef] [PubMed]

209. Delarue, M.; Duclert-Savatier, N.; Miclet, E.; Haouz, A.; Giganti, D.; Ouazzani, J.; Lopez, P.; Nilges, M.; Stoven, V. Three dimensional structure and implications for the catalytic mechanism of 6-phosphogluconolactonase from Trypanosoma brucei. J. Mol. Biol. 2007, 366, 868-881. [CrossRef] [PubMed]

210. Duclert-Savatier, N.; Poggi, L.; Miclet, E.; Lopes, P.; Ouazzani, J.; Chevalier, N.; Nilges, M.; Delarue, M.; Stoven, V. Insights into the enzymatic mechanism of 6-phosphogluconolactonase from Trypanosoma brucei using structural data and molecular dynamics simulation. J. Mol. Biol. 2009, 388, 1009-1021. [CrossRef] [PubMed]

211. Phillips, C.; Dohnalek, J.; Gover, S.; Barrett, M.P.; Adams, M.J. A $2.8 \AA$ resolution structure of 6-phosphogluconate dehydrogenase from the protozoan parasite Trypanosoma brucei: Comparison with the sheep enzyme accounts for differences in activity with coenzyme and substrate analogues. J. Mol. Biol. 1998, 282, 667-681. [CrossRef] [PubMed]

212. Cordeiro, A.T.; Michels, P.A.; Delboni, L.F.; Thiemann, O.H. The crystal structure of glucose-6-phosphate isomerase from Leishmania mexicana reveals novel active site features. Eur. J. Biochem. 2004, 271, 2765-2772. [CrossRef] [PubMed]

213. Arsenieva, D.; Appavu, B.L.; Mazock, G.H.; Jeffery, C.J. Crystal structure of phosphoglucose isomerase from Trypanosoma brucei complexed with glucose-6-phosphate at $1.6 \AA$ resolution. Proteins 2009, 74, 72-80. [CrossRef] [PubMed]

214. Smith, C.D.; Chattopadhyay, D.; Pal, B. Crystal structure of Plasmodium falciparum phosphoglycerate kinase: Evidence for anion binding in the basic patch. Biochem. Biophys. Res. Commun. 2011, 412, 203-206. [CrossRef] [PubMed]

215. Bernstein, B.E.; Michels, P.A.; Hol, W.G. Synergistic effects of substrate-induced conformational changes in phosphoglycerate kinase activation. Nature 1997, 385, 275-278. [CrossRef] [PubMed]

216. Bernstein, B.E.; Williams, D.M.; Bressi, J.C.; Kuhn, P.; Gelb, M.H.; Blackburn, G.M.; Hol, W.G. A bisubstrate analog induces unexpected conformational changes in phosphoglycerate kinase from Trypanosoma brucei. J. Mol. Biol. 1998, 279, 1137-1148. [CrossRef] [PubMed]

217. Nowicki, M.W.; Kuaprasert, B.; McNae, I.W.; Morgan, H.P.; Harding, M.M.; Michels, P.A.; Fothergill-Gilmore, L.A.; Walkinshaw, M.D. Crystal structures of Leishmania mexicana phosphoglycerate mutase suggest a one-metal mechanism and a new enzyme subclass. J. Mol. Biol. 2009, 394, 535-543. [CrossRef] [PubMed]

218. Hills, T.; Srivastava, A.; Ayi, K.; Wernimont, A.K.; Kain, K.; Waters, A.P.; Hui, R.; Pizarro, J.C. Characterization of a new phosphatase from Plasmodium. Mol. Biochem. Parasitol. 2011, 179, 69-79. [CrossRef] [PubMed]

219. Mercaldi, G.F.; Pereira, H.M.; Cordeiro, A.T.; Michels, P.A.; Thiemann, O.H. Structural role of the active-site metal in the conformation of Trypanosoma brucei phosphoglycerate mutase. FEBS J. 2012, 279, 2012-2021. [CrossRef] [PubMed]

220. Kedzierski, L.; Malby, R.L.; Smith, B.J.; Perugini, M.A.; Hodder, A.N.; Ilg, T.; Colman, P.M.; Handman, E. Structure of Leishmania mexicana phosphomannomutase highlights similarities with human isoforms. J. Mol. Biol. 2006, 363, 215-227. [CrossRef] [PubMed]

221. Wernimont, A.K.; Lam, A.; Ali, A.; Lin, Y.H.; Guther, L.; Shamshad, A.; Bandini, G.; MacKenzie, F.; Kozieradzki, I.; Cossar, D.; et al. Crystal structure of Trypanosoma brucei phosphomannosemutase, TB.10.700.370. Unpublished work, 2009, doi:10.2210/pdb3f9r/pdb.

222. Liu, P.; Marzahn, M.R.; Robbins, A.H.; Gutiérrez-de-Terán, H.; Rodríguez, D.; McClung, S.H.; Stevens, S.M.; Yowell, C.A.; Dame, J.B.; McKenna, R.; et al. Recombinant plasmepsin 1 from the human malaria parasite Plasmodium falciparum: Enzymatic characterization, active site inhibitor design, and structural analysis. Biochemistry 2009, 48, 4086-4099. [CrossRef] [PubMed] 
223. Bhaumik, P.; Horimoto, Y.; Xiao, H.; Miura, T.; Hidaka, K.; Kiso, Y.; Wlodawer, A.; Yada, R.Y.; Gustchina, A. Crystal structures of the free and inhibited forms of plasmepsin I (PMI) from Plasmodium falciparum. J. Struct. Biol. 2011, 175, 73-84. [CrossRef] [PubMed]

224. Silva, A.M.; Lee, A.Y.; Gulnik, S.V.; Maier, P.; Collins, J.; Bhat, T.N.; Collins, P.J.; Cachau, R.E.; Luker, K.E.; Gluzman, I.Y.; et al. Structure and inhibition of plasmepsin II, a hemoglobin-degrading enzyme from Plasmodium falciparum. Proc. Natl. Acad. Sci. USA 1996, 93, 10034-10039. [CrossRef] [PubMed]

225. Asojo, O.A.; Afonina, E.; Gulnik, S.V.; Yu, B.; Erickson, J.W.; Randad, R.; Medjahed, D.; Silva, A.M. Structures of Ser205 mutant plasmepsin II from Plasmodium falciparum at $1.8 \AA$ in complex with the inhibitors rs 367 and rs370. Acta Crystallogr. D Biol. Crystallogr. 2002, 58, 2001-2008. [CrossRef] [PubMed]

226. Asojo, O.A.; Gulnik, S.V.; Afonina, E.; Yu, B.; Ellman, J.A.; Haque, T.S.; Silva, A.M. Novel uncomplexed and complexed structures of plasmepsin II, an aspartic protease from Plasmodium falciparum. J. Mol. Biol. 2003, 327, 173-181. [CrossRef]

227. Prade, L.; Jones, A.F.; Boss, C.; Richard-Bildstein, S.; Meyer, S.; Binkert, C.; Bur, D. X-ray structure of plasmepsin II complexed with a potent achiral inhibitor. J. Biol. Chem. 2005, 280, 23837-23843. [CrossRef] [PubMed]

228. Boss, C.; Corminboeuf, O.; Grisostomi, C.; Meyer, S.; Jones, A.F.; Prade, L.; Binkert, C.; Fischli, W.; Weller, T.; Bur, D. Achiral, cheap, and potent inhibitors of Plasmepsins I, II, and IV. ChemMedChem 2006, 1, 1341-1345. [CrossRef] [PubMed]

229. Robbins, A.H.; Dunn, B.M.; Agbandje-McKenna, M.; McKenna, R. Crystallographic evidence for noncoplanar catalytic aspartic acids in plasmepsin II resides in the Protein Data Bank. Acta Crystallogr. D Biol. Crystallogr. 2009, 65, 294-296. [CrossRef] [PubMed]

230. Asojo, O.A.; Silva, A.M.; Gulnik, S. Novel uncomplexed and complex structures of PM II, an aspartic protease from P. falciparum. Unpublished work, 2005, doi:10.2210/pdb1m43/pdb.

231. Freire, E.; Nezami, A.G.; Amzel, L.M. Crystal structure of plasmepsin II, an aspartyl protease from Plasmodium falciparum, in complex with a statine-based inhibitor. Unpublished work, 2004, doi:10.2210/ $\mathrm{pdb} 1 \mathrm{me} 6 / \mathrm{pdb}$.

232. Lindberg, J.; Johansson, P.-O.; Rosenquist, A.; Kvarnstroem, I.; Vrang, L.; Samuelsson, B.; Unge, T. Structural study of a novel inhibitor with bulky P1 side chain in complex with Plasmepsin II-Implications for drug design. Unpublished work, 2006, doi:10.2210/pdb1w6h/pdb, doi:10.2210/pdb1w6i/pdb.

233. Prade, L. Structure of plasmepsin II. Unpublished work, 2005, doi:10.2210/pdb1xdh/pdb, doi:10.2210/ pdb1xe5/pdb, doi:10.2210/pdb1xe6/pdb.

234. Buschiazzo, A.; Goytia, M.; Schaeffer, F.; Degrave, W.; Shepard, W.; Grégoire, C.; Chamond, N.; Cosson, A.; Berneman, A.; Coatnoan, N.; et al. Crystal structure, catalytic mechanism, and mitogenic properties of Trypanosoma cruzi proline racemase. Proc. Natl. Acad. Sci. USA 2006, 103, 1705-1710. [CrossRef] [PubMed]

235. Holton, S.; Merckx, A.; Burgess, D.; Doerig, C.; Noble, M.; Endicott, J. Structures of P. falciparum PfPK5 test the CDK regulation paradigm and suggest mechanisms of small molecule inhibition. Structure 2003, 11, 1329-1337. [CrossRef] [PubMed]

236. Chou, S.; Jensen, B.C.; Parsons, M.; Alber, T.; Grundner, C. The Trypanosoma brucei life cycle switch TbPTP1 is structurally conserved and dephosphorylates the nucleolar protein NOPP44/46. J. Biol. Chem. 2010, 285, 22075-22081. [CrossRef] [PubMed]

237. Lountos, G.T.; Tropea, J.E.; Waugh, D.S. Structure of the Trypanosoma cruzi protein tyrosine phosphatase TcPTP1, a potential therapeutic target for Chagas' disease. Mol. Biochem. Parasitol. 2013, 187, 1-8. [CrossRef] [PubMed]

238. Barrack, K.L.; Tulloch, L.B.; Burke, L.A.; Fyfe, P.K.; Hunter, W.N. Structure of recombinant Leishmania donovani pteridine reductase reveals a disordered active site. Acta Crystallogr. Sect. F Struct. Biol. Cryst. Commun. 2011, 67, 33-37. [CrossRef] [PubMed]

239. Gourley, D.G.; Schüttelkopf, A.W.; Leonard, G.A.; Luba, J.; Hardy, L.W.; Beverley, S.M.; Hunter, W.N. Pteridine reductase mechanism correlates pterin metabolism with drug resistance in trypanosomatid parasites. Nat. Struct. Biol. 2001, 8, 521-525. [CrossRef] [PubMed]

240. McLuskey, K.; Gibellini, F.; Carvalho, P.; Avery, M.A.; Hunter, W.N. Inhibition of Leishmania major pteridine reductase by 2,4,6-triaminoquinazoline: Structure of the NADPH ternary complex. Acta Crystallogr. D Biol. Crystallogr. 2004, 60, 1780-1785. [CrossRef] [PubMed] 
241. Schüttelkopf, A.W.; Hardy, L.W.; Beverley, S.M.; Hunter, W.N. Structures of Leishmania major pteridine reductase complexes reveal the active site features important for ligand binding and to guide inhibitor design. J. Mol. Biol. 2005, 352, 105-116. [CrossRef] [PubMed]

242. Cavazzuti, A.; Paglietti, G.; Hunter, W.N.; Gamarro, F.; Piras, S.; Loriga, M.; Allecca, S.; Corona, P.; McLuskey, K.; Tulloch, L.; et al. Discovery of potent pteridine reductase inhibitors to guide antiparasite drug development. Proc. Natl. Acad. Sci. USA 2008, 105, 1448-1453. [CrossRef] [PubMed]

243. Dawson, A.; Gibellini, F.; Sienkiewicz, N.; Tulloch, L.B.; Fyfe, P.K.; McLuskey, K.; Fairlamb, A.H.; Hunter, W.N. Structure and reactivity of Trypanosoma brucei pteridine reductase: Inhibition by the archetypal antifolate methotrexate. Mol. Microbiol. 2006, 61, 1457-1468. [CrossRef] [PubMed]

244. Mpamhanga, C.P.; Spinks, D.; Tulloch, L.B.; Shanks, E.J.; Robinson, D.A.; Collie, I.T.; Fairlamb, A.H.; Wyatt, P.G.; Frearson, J.A.; Hunter, W.N.; et al. One scaffold, three binding modes: Novel and selective pteridine reductase 1 inhibitors derived from fragment hits discovered by virtual screening. J. Med. Chem. 2009, 52, 4454-4465. [CrossRef] [PubMed]

245. Shanks, E.J.; Ong, H.B.; Robinson, D.A.; Thompson, S.; Sienkiewicz, N.; Fairlamb, A.H.; Frearson, J.A. Development and validation of a cytochrome c-coupled assay for pteridine reductase 1 and dihydrofolate reductase. Anal. Biochem. 2010, 396, 194-203. [CrossRef] [PubMed]

246. Tulloch, L.B.; Martini, V.P.; Iulek, J.; Huggan, J.K.; Lee, J.H.; Gibson, C.L.; Smith, T.K.; Suckling, C.J.; Hunter, W.N. Structure-based design of pteridine reductase inhibitors targeting African sleeping sickness and the leishmaniases. J. Med. Chem. 2010, 53, 221-229. [CrossRef] [PubMed]

247. Dawson, A.; Tulloch, L.B.; Barrack, K.L.; Hunter, W.N. High-resolution structures of Trypanosoma brucei pteridine reductase ligand complexes inform on the placement of new molecular entities in the active site of a potential drug target. Acta Crystallogr. D Biol. Crystallogr. 2010, 66, 1334-1340. [CrossRef] [PubMed]

248. Nerini, E.; Dawson, A.; Hannaert, V.; Michels, P.A.; Hunter, W.N.; Costi, M.P. Structural studies of thiadiazole derivatives that inhibit Trypanosoma brucei growth. Unpublished work, 2012, doi:10.2210/pdb2yhi/pdb.

249. Schormann, N.; Pal, B.; Senkovich, O.; Carson, M.; Howard, A.; Smith, C.; Delucas, L.; Chattopadhyay, D. Crystal structure of Trypanosoma cruzi pteridine reductase 2 in complex with a substrate and an inhibitor. J. Struct. Biol. 2005, 152, 64-75. [CrossRef] [PubMed]

250. Shi, W.; Ting, L.M.; Kicska, G.A.; Lewandowicz, A.; Tyler, P.C.; Evans, G.B.; Furneaux, R.H.; Kim, K.; Almo, S.C.; Schramm, V.L. Plasmodium falciparum purine nucleoside phosphorylase: Crystal structures, immucillin inhibitors, and dual catalytic function. J. Biol. Chem. 2004, 279, 18103-18106. [CrossRef] [PubMed]

251. Schnick, C.; Robien, M.A.; Brzozowski, A.M.; Dodson, E.J.; Murshudov, G.N.; Anderson, L.; Luft, J.R.; Mehlin, C.; Hol, W.G.; Brannigan, J.A.; et al. Structures of Plasmodium falciparum purine nucleoside phosphorylase complexed with sulfate and its natural substrate inosine. Acta Crystallogr. D Biol. Crystallogr. 2005, 61, 1245-1254. [CrossRef] [PubMed]

252. Chaikuad, A.; Brady, R.L. Conservation of structure and activity in Plasmodium purine nucleoside phosphorylases. BMC Struct. Biol. 2009, 9, 42. [CrossRef] [PubMed]

253. Jones, D.C.; Alphey, M.S.; Wyllie, S.; Fairlamb, A.H. Chemical, genetic and structural assessment of pyridoxal kinase as a drug target in the African trypanosome. Mol. Microbiol. 2012, 86, 51-64. [CrossRef] [PubMed]

254. Rigden, D.J.; Phillips, S.E.; Michels, P.A.; Fothergill-Gilmore, L.A. The structure of pyruvate kinase from Leishmania mexicana reveals details of the allosteric transition and unusual effector specificity. J. Mol. Biol. 1999, 291, 615-635. [CrossRef] [PubMed]

255. Tulloch, L.B.; Morgan, H.P.; Hannaert, V.; Michels, P.A.; Fothergill-Gilmore, L.A.; Walkinshaw, M.D. Sulphate removal induces a major conformational change in Leishmania mexicana pyruvate kinase in the crystalline state. J. Mol. Biol. 2008, 383, 615-626. [CrossRef] [PubMed]

256. Morgan, H.P.; McNae, I.W.; Hsin, K.Y.; Michels, P.A.; Fothergill-Gilmore, L.A.; Walkinshaw, M.D. An improved strategy for the crystallization of Leishmania mexicana pyruvate kinase. Acta Crystallogr. Sect. F Struct. Biol. Cryst. Commun. 2010, 66, 215-218. [CrossRef] [PubMed]

257. Morgan, H.P.; McNae, I.W.; Nowicki, M.W.; Hannaert, V.; Michels, P.A.; Fothergill-Gilmore, L.A.; Walkinshaw, M.D. Allosteric mechanism of pyruvate kinase from Leishmania mexicana uses a rock and lock model. J. Biol. Chem. 2010, 285, 12892-12898. [CrossRef] [PubMed] 
258. Morgan, H.P.; McNae, I.W.; Nowicki, M.W.; Zhong, W.; Michels, P.A.; Auld, D.S.; Fothergill-Gilmore, L.A.; Walkinshaw, M.D. The trypanocidal drug suramin and other trypan blue mimetics are inhibitors of pyruvate kinases and bind to the adenosine site. J. Biol. Chem. 2011, 286, 31232-31240. [CrossRef] [PubMed]

259. Morgan, H.P.; Walsh, M.; Blackburn, E.A.; Wear, M.A.; Boxer, M.; Shen, M.; McNae, I.W.; Michels, P.A.M.; Auld, D.S.; Fothergill-Gilmore, L.A.; et al. A new class of suicide inhibitor blocks nucleotide binding to pyruvate kinase. Unpublished work, 2012, doi:10.2210/pdb3srk/pdb.

260. Wernimont, A.K.; Hutchinson, A.; Hassanali, A.; Mackenzie, F.; Cossar, D.; Bochkarev, A.; Arrowsmith, C.H.; Bountra, C.; Weigelt, J.; Edwards, A.M.; et al. Crystal structure of PFF1300w. Unpublished work, 2005, doi:10.2210/pdb3khd/pdb.

261. Zhong, W.; Morgan, H.P.; McNae, I.W.; Michels, P.A.; Fothergill-Gilmore, L.A.; Walkinshaw, M.D. 'In crystallo' substrate binding triggers major domain movements and reveals magnesium as a co-activator of Trypanosoma brucei pyruvate kinase. Acta Crystallogr. D Biol. Crystallogr. 2013, 69, 1768-1779. [CrossRef] [PubMed]

262. Zhong, W.; Morgan, H.P.; Nowicki, M.W.; McNae, I.W.; Yuan, M.; Bella, J.; Michels, P.A.; Fothergill-Gilmore, L.A.; Walkinshaw, M.D. Pyruvate kinases have an intrinsic and conserved decarboxylase activity. Biochem. J. 2014, 458, 301-311. [CrossRef] [PubMed]

263. Marion, R.; Hansell, E.; Caffrey, C.; Roush, W.R.; Brinen, L.S. The high resolution structure of rhodesain, the major cathepsin L protease from Trypanosoma brucei rhodesiense, illustrates the basis for differences in inhibition profiles from other papain family cysteine proteases. Unpublished work, 2008, doi:10.2210/pdb2p86/pdb.

264. Stern, A.L.; Naworyta, A.; Cazzulo, J.J.; Mowbray, S.L. Structures of type B ribose 5-phosphate isomerase from Trypanosoma cruzi shed light on the determinants of sugar specificity in the structural family. FEBS J. 2011, 278, 793-808. [CrossRef] [PubMed]

265. Caruthers, J.; Bosch, J.; Buckner, F.; van Voorhis, W.; Myler, P.; Worthey, E.; Mehlin, C.; Boni, E.; DeTitta, G.; Luft, J.; et al. Structure of a ribulose 5-phosphate 3-epimerase from Plasmodium falciparum. Proteins 2006, 62, 338-342. [CrossRef] [PubMed]

266. Deng, J.; Schnaufer, A.; Salavati, R.; Stuart, K.D.; Hol, W.G. High resolution crystal structure of a key editosome enzyme from Trypanosoma brucei: RNA editing ligase 1. J. Mol. Biol. 2004, 343, 601-613. [CrossRef] [PubMed]

267. Siponen, M.I.; Welin, M.; Arrowsmith, C.H.; Berglund, H.; Bountra, C.; Collins, R.; Dahlgren, L.G.; Edwards, A.M.; Flodin, S.; Flores, A.; et al. Crystal structure of Leishmania major S-adenosylhomocysteine hydrolase. Unpublished work, 2009, doi:10.2210/pdb3g1u/pdb.

268. Tanaka, N.; Nakanishi, M.; Kusakabe, Y.; Shiraiwa, K.; Yabe, S.; Ito, Y.; Kitade, Y.; Nakamura, K.T. Crystal structure of $S$-adenosyl-L-homocysteine hydrolase from the human malaria parasite Plasmodium falciparum. J. Mol. Biol. 2004, 343, 1007-1017. [CrossRef] [PubMed]

269. Siponen, M.I.; Schutz, P.; Arrowsmith, C.H. Crystal structure of S-adenosyl homocysteine hydrolase (SAHH) from Trypanosoma brucei. Unpublished work, 2009, doi:10.2210/pdb3h9u/pdb.

270. Larson, E.T.; Zhang, L.; Napuli, A.; Mueller, N.; Verlinde, C.L.M.J.; van Voorhis, W.C.; Buckner, F.S.; Fan, E.; Hol, W.G.J.; Merritt, E.A. X-ray crystal structure of Seryl-tRNA synthetase from the eukaryotic parasite Trypanosoma brucei. Unpublished work, 2010, doi:10.2210/pdb3lsq/pdb, doi:10.2210/pdb3lss/pdb.

271. Zhu, A.Y.; Zhou, Y.; Khan, S.; Deitsch, K.W.; Hao, Q.; Lin, H. Plasmodium falciparum Sir2A preferentially hydrolyzes medium and long chain fatty acyl lysine. ACS Chem. Biol. 2012, 7, 155-159. [CrossRef] [PubMed]

272. Dufe, V.T.; Qiu, W.; Müller, I.B.; Hui, R.; Walter, R.D.; Al-Karadaghi, S. Crystal structure of Plasmodium falciparum spermidine synthase in complex with the substrate decarboxylated S-adenosylmethionine and the potent inhibitors 4MCHA and AdoDATO. J. Mol. Biol. 2007, 373, 167-177. [CrossRef] [PubMed]

273. Qiu, W.; Dong, A.; Ren, H.; Wu, H.; Zhao, Y.; Schapira, M.; Wasney, G.; Vedadi, M.; Lew, J.; Kozieradzki, I.; Edwards, A.M.; et al. Crystal structure of spermidine synthase from Plasmodium falciparum, Unpublished work, 2007, doi:10.2210/pdb2pwp/pdb.

274. Burger, P.B.; Williams, M.; Reeksting, S.B.; Muller, I.B.; Al-Karadaghi, S.; Briggs, J.M.; Joubert, F.; Birkholtz, L.; Louw, A.I. Insights into the design of novel inhibitors against Plasmodium falciparum spermidine synthase using structurally derived binding descriptors. Unpublished work, 2012, doi:10.2210/pdb3rie/pdb.

275. Bosch, J.; Arakaki, T.L.; Le Trong, I.; Merritt, E.A.; Hol, W.G.J. Crystal structure of spermidine synthase from Trypanosoma cruzi. Unpublished work, 2008, doi:10.2210/pdb3bwc/pdb. 
276. Hargrove, T.Y.; Wawrzak, Z.; Liu, J.; Nes, W.D.; Waterman, M.R.; Lepesheva, G.I. Substrate preferences and catalytic parameters determined by structural characteristics of sterol $14 \alpha$-demethylase (CYP51) from Leishmania infantum. J. Biol. Chem. 2011, 286, 26838-26848. [CrossRef] [PubMed]

277. Lepesheva, G.I.; Park, H.W.; Hargrove, T.Y.; Vanhollebeke, B.; Wawrzak, Z.; Harp, J.M.; Sundaramoorthy, M.; Nes, W.D.; Pays, E.; Chaudhuri, M.; et al. Crystal structures of Trypanosoma brucei sterol 14 $\alpha$-demethylase and implications for selective treatment of human infections. J. Biol. Chem. 2010, 285, 1773-1780. [CrossRef] [PubMed]

278. Chen, C.K.; Leung, S.S.; Guilbert, C.; Jacobson, M.P.; McKerrow, J.H.; Podust, L.M. Structural characterization of CYP51 from Trypanosoma cruzi and Trypanosoma brucei bound to the antifungal drugs posaconazole and fluconazole. PLoS Negl. Trop. Dis. 2010, 4, e651. [CrossRef] [PubMed]

279. Hargrove, T.Y.; Wawrzak, Z.; Liu, J.; Waterman, M.R.; Nes, W.D.; Lepesheva, G.I. Structural complex of sterol $14 \alpha$-demethylase (CYP51) with $14 \alpha$-methylenecyclopropyl- $\Delta 7-24,25$-dihydrolanosterol. J. Lipid Res. 2012, 53, 311-320. [CrossRef] [PubMed]

280. Buckner, F.S.; Bahia, M.T.; Suryadevara, P.K.; White, K.L.; Shackleford, D.M.; Chennamaneni, N.K.; Hulverson, M.A.; Laydbak, J.U.; Chatelain, E.; Scandale, I.; et al. Pharmacological characterization, structural studies, and in vivo activities of anti-Chagas disease lead compounds derived from tipifarnib. Antimicrob. Agents Chemother. 2012, 56, 4914-4921. [CrossRef] [PubMed]

281. Choi, J.Y.; Calvet, C.M.; Gunatilleke, S.S.; Ruiz, C.; Cameron, M.D.; McKerrow, J.H.; Podust, L.M.; Roush, W.R. Rational development of 4-aminopyridyl-based inhibitors targeting Trypanosoma cruzi CYP51 as anti-Chagas agents. J. Med. Chem. 2013, 56, 7651-7668. [CrossRef] [PubMed]

282. Hargrove, T.Y.; Wawrzak, Z.; Waterman, M.R.; Lepesheva, G.I. CYP51 structure-based VNI scaffold development. Unpublished work, 2005, doi:10.2210/pdb4g7g/pdb.

283. Lepesheva, G.I.; Hargrove, T.Y.; Anderson, S.; Kleshchenko, Y.; Furtak, V.; Wawrzak, Z.; Villalta, F.; Waterman, M.R. Structural insights into inhibition of sterol $14 \alpha$-demethylase in the human pathogen Trypanosoma cruzi. J. Biol. Chem. 2010, 285, 25582-25590. [CrossRef] [PubMed]

284. Andriani, G.; Amata, E.; Beatty, J.; Clements, Z.; Coffey, B.J.; Courtemanche, G.; Devine, W.; Erath, J.; Juda, C.E.; Wawrzak, Z.; et al. Antitrypanosomal lead discovery: Identification of a ligand-efficient inhibitor of Trypanosoma cruzi CYP51 and parasite growth. J. Med. Chem. 2013, 56, 2556-2567. [CrossRef] [PubMed]

285. Hargrove, T.Y.; Wawrzak, Z.; Alexander, P.W.; Chaplin, J.H.; Keenan, M.; Charman, S.A.; Perez, C.J.; Waterman, M.R.; Chatelain, E.; Lepesheva, G.I. Complexes of Trypanosoma cruzi sterol $14 \alpha$-demethylase (CYP51) with two pyridine-based drug candidates for Chagas disease: Structural basis for pathogen selectivity. J. Biol. Chem. 2013, 288, 31602-31615. [CrossRef] [PubMed]

286. Vieira, D.F.; Choi, J.Y.; Roush, W.R.; Podust, L.M. Expanding the binding envelope of CYP51 inhibitors targeting Trypanosoma cruzi with 4-aminopyridyl-based sulfonamide derivatives. ChemBiochem 2014, 15, 1111-1120. [CrossRef] [PubMed]

287. Choi, J.Y.; Calvet, C.M.; Vieira, D.F.; Gunatilleke, S.S.; Cameron, M.D.; Mckerrow, J.H.; Podust, L.M.; Roush, W.R. R-Configuration of 4-aminopyridyl-based inhibitors of CYP51 confers superior efficacy against Trypanosoma cruzi. ACS Med. Chem. Lett. 2014, 5, 434-439. [CrossRef] [PubMed]

288. Calvet, C.M.; Vieira, D.F.; Choi, J.Y.; Kellar, D.; Cameron, M.D.; Siqueira-Neto, J.L.; Gut, J.; Johnston, J.B.; Lin, L.; et al. 4-Aminopyridyl-based CYP51 inhibitors as anti-Trypanosoma cruzi drug leads with improved pharmacokinetic profile and in vivo potency. J. Med. Chem. 2014, 57, 6989-7005. [CrossRef] [PubMed]

289. Harijan, R.K.; Kiema, T.R.; Karjalainen, M.P.; Janardan, N.; Murthy, M.R.; Weiss, M.S.; Michels, P.A.; Wierenga, R.K. Crystal structures of SCP2-thiolases of Trypanosomatidae, human pathogens causing widespread tropical diseases: The importance for catalysis of the cysteine of the unique HDCF loop. Biochem. J. 2013, 455, 119-130. [CrossRef] [PubMed]

290. Boucher, I.W.; Brzozowski, A.M.; Brannigan, J.A.; Schnick, C.; Smith, D.J.; Kyes, S.A.; Wilkinson, A.J. The crystal structure of superoxide dismutase from Plasmodium falciparum. BMC Struct. Biol. 2006, 6, 20. [CrossRef] [PubMed]

291. Bachega, J.F.; Navarro, M.V.; Bleicher, L.; Bortoleto-Bugs, R.K.; Dive, D.; Hoffmann, P.; Viscogliosi, E.; Garratt, R.C. Systematic structural studies of iron superoxide dismutases from human parasites and a statistical coupling analysis of metal binding specificity. Proteins 2009, 77, 26-37. [CrossRef] [PubMed]

292. Deng, J.; Ernst, N.L.; Turley, S.; Stuart, K.D.; Hol, W.G. Structural basis for UTP specificity of RNA editing TUTases from Trypanosoma brucei. EMBO J. 2005, 24, 4007-4017. [CrossRef] [PubMed] 
293. Stagno, J.; Aphasizheva, I.; Rosengarth, A.; Luecke, H.; Aphasizhev, R. UTP-bound and Apo structures of a minimal RNA uridylyltransferase. J. Mol. Biol. 2007, 366, 882-899. [CrossRef] [PubMed]

294. Stagno, J.; Aphasizheva, I.; Aphasizhev, R.; Luecke, H. Dual role of the RNA substrate in selectivity and catalysis by terminal uridylyl transferases. Proc. Natl. Acad. Sci. USA 2007, 104, 14634-14639. [CrossRef] [PubMed]

295. Saab-Rincón, G.; Olvera, L.; Olvera, M.; Rudiño-Piñera, E.; Benites, E.; Soberón, X.; Morett, E. Evolutionary walk between $(\beta / \alpha)(8)$ barrels: Catalytic migration from triosephosphate isomerase to thiamin phosphate synthase. J. Mol. Biol. 2012, 416, 255-270. [CrossRef] [PubMed]

296. Fyfe, P.K.; Westrop, G.D.; Silva, A.M.; Coombs, G.H.; Hunter, W.N. Leishmania TDR1 structure, a unique trimeric glutathione transferase capable of deglutathionylation and antimonial prodrug activation. Proc. Natl. Acad. Sci. USA 2012, 109, 11693-11698. [CrossRef] [PubMed]

297. Fritz-Wolf, K.; Jortzik, E.; Stumpf, M.; Preuss, J.; Iozef, R.; Rahlfs, S.; Becker, K. Crystal structure of the Plasmodium falciparum thioredoxin reductase-thioredoxin complex. J. Mol. Biol. 2013, 425, 3446-3460. [CrossRef] [PubMed]

298. Whittingham, J.L.; Carrero-Lerida, J.; Brannigan, J.A.; Ruiz-Perez, L.M.; Silva, A.P.; Fogg, M.J.; Wilkinson, A.J.; Gilbert, I.H.; Wilson, K.S.; González-Pacanowska, D. Structural basis for the efficient phosphorylation of AZT-MP (3'-azido-3'-deoxythymidine monophosphate) and dGMP by Plasmodium falciparum type I thymidylate kinase. Biochem. J. 2010, 428, 499-509. [CrossRef] [PubMed]

299. Cui, H.; Carrero-Lérida, J.; Silva, A.P.; Whittingham, J.L.; Brannigan, J.A.; Ruiz-Pérez, L.M.; Read, K.D.; Wilson, K.S.; González-Pacanowska, D.; Gilbert, I.H. Synthesis and evaluation of $\alpha$-thymidine analogues as novel antimalarials. J. Med. Chem. 2012, 55, 10948-10957. [CrossRef] [PubMed]

300. Veitch, N.J.; Maugeri, D.A.; Cazzulo, J.J.; Lindqvist, Y.; Barrett, M.P. Transketolase from Leishmania mexicana has a dual subcellular localization. Biochem. J. 2004, 382, 759-767. [CrossRef] [PubMed]

301. Eichhorn, T.; Winter, D.; Büchele, B.; Dirdjaja, N.; Frank, M.; Lehmann, W.D.; Mertens, R.; Krauth-Siegel, R.L.; Simmet, T.; Granzin, J.; et al. Molecular interaction of artemisinin with translationally controlled tumor protein (TCTP) of Plasmodium falciparum. Biochem. Pharmacol. 2013, 85, 38-45. [CrossRef] [PubMed]

302. Buschiazzo, A.; Amaya, M.F.; Cremona, M.L.; Frasch, A.C.; Alzari, P.M. The crystal structure and mode of action of trans-sialidase, a key enzyme in Trypanosoma cruzi pathogenesis. Mol. Cell 2002, 10, 757-768. [CrossRef]

303. Amaya, M.F.; Watts, A.G.; Damager, I.; Wehenkel, A.; Nguyen, T.; Buschiazzo, A.; Paris, G.; Frasch, A.C.; Withers, S.G.; Alzari, P.M. Structural insights into the catalytic mechanism of Trypanosoma cruzi trans-sialidase. Structure 2004, 12, 775-784. [CrossRef] [PubMed]

304. Buchini, S.; Buschiazzo, A.; Withers, S.G. A new generation of specific Trypanosoma cruzi trans-sialidase inhibitors. Angew. Chem. Int. Ed. Engl. 2008, 47, 2700-2703. [CrossRef] [PubMed]

305. Buschiazzo, A.; Muiá, R.; Larrieux, N.; Pitcovsky, T.; Mucci, J.; Campetella, O. Trypanosoma cruzi trans-sialidase in complex with a neutralizing antibody: Structure/function studies towards the rational design of inhibitors. PLoS Pathog. 2012, 8, e1002474. [CrossRef] [PubMed]

306. Williams, J.C.; Zeelen, J.P.; Neubauer, G.; Vriend, G.; Backmann, J.; Michels, P.A.; Lambeir, A.M.; Wierenga, R.K. Structural and mutagenesis studies of Leishmania triosephosphate isomerase: A point mutation can convert a mesophilic enzyme into a superstable enzyme without losing catalytic power. Protein Eng. 1999, 12, 243-250. [CrossRef] [PubMed]

307. Kursula, I.; Partanen, S.; Lambeir, A.M.; Antonov, D.M.; Augustyns, K.; Wierenga, R.K. Structural determinants for ligand binding and catalysis of triosephosphate isomerase. Eur. J. Biochem. 2001, 268, 5189-5196. [CrossRef] [PubMed]

308. Kursula, I.; Wierenga, R.K. Crystal structure of triosephosphate isomerase complexed with 2-phosphoglycolate at 0.83-Å resolution. J. Biol. Chem. 2003, 278, 9544-9551. [CrossRef] [PubMed]

309. Alahuhta, M.; Wierenga, R.K. Atomic resolution crystallography of a complex of triosephosphate isomerase with a reaction-intermediate analog: New insight in the proton transfer reaction mechanism. Proteins 2010, 78, 1878-1888. [CrossRef] [PubMed]

310. Venkatesan, R.; Alahuhta, M.; Pihko, P.M.; Wierenga, R.K. High resolution crystal structures of triosephosphate isomerase complexed with its suicide inhibitors: The conformational flexibility of the catalytic glutamate in its closed, liganded active site. Protein Sci. 2011, 20, 1387-1397. [CrossRef] [PubMed] 
311. Velanker, S.S.; Ray, S.S.; Gokhale, R.S.; Suma, S.; Balaram, H.; Balaram, P.; Murthy, M.R. Triosephosphate isomerase from Plasmodium falciparum: The crystal structure provides insights into antimalarial drug design. Structure 1997, 5, 751-761. [CrossRef]

312. Parthasarathy, S.; Ravindra, G.; Balaram, H.; Balaram, P.; Murthy, M.R. Structure of the Plasmodium falciparum triosephosphate isomerase-phosphoglycolate complex in two crystal forms: Characterization of catalytic loop open and closed conformations in the ligand-bound state. Biochemistry 2002, 41, 13178-13188. [CrossRef] [PubMed]

313. Parthasarathy, S.; Balaram, H.; Balaram, P.; Murthy, M.R. Structures of Plasmodium falciparum triosephosphate isomerase complexed to substrate analogues: Observation of the catalytic loop in the open conformation in the ligand-bound state. Acta Crystallogr. D Biol. Crystallogr. 2002, 58, 1992-2000. [CrossRef] [PubMed]

314. Parthasarathy, S.; Eaazhisai, K.; Balaram, H.; Balaram, P.; Murthy, M.R. Structure of Plasmodium falciparum triose-phosphate isomerase-2-phosphoglycerate complex at 1.1- $\AA$ resolution. J. Biol. Chem. 2003, 278, 52461-52470. [CrossRef] [PubMed]

315. Gayathri, P.; Banerjee, M.; Vijayalakshmi, A.; Balaram, H.; Balaram, P.; Murthy, M.R. Biochemical and structural characterization of residue 96 mutants of Plasmodium falciparum triosephosphate isomerase: Active-site loop conformation, hydration and identification of a dimer-interface ligand-binding site. Acta Crystallogr. D Biol. Crystallogr. 2009, 65, 847-857. [CrossRef] [PubMed]

316. Verlinde, C.L.; Noble, M.E.; Kalk, K.H.; Groendijk, H.; Wierenga, R.K.; Hol, W.G. Anion binding at the active site of trypanosomal triosephosphate isomerase. Monohydrogen phosphate does not mimic sulphate. Eur. J. Biochem. 1991, 198, 53-57. [CrossRef] [PubMed]

317. Wierenga, R.K.; Noble, M.E.; Postma, J.P.; Groendijk, H.; Kalk, K.H.; Hol, W.G.; Opperdoes, F.R. The crystal structure of the "open" and the "closed" conformation of the flexible loop of trypanosomal triosephosphate isomerase. Proteins 1991, 10, 33-49. [CrossRef] [PubMed]

318. Noble, M.E.; Wierenga, R.K.; Lambeir, A.M.; Opperdoes, F.R.; Thunnissen, A.M.; Kalk, K.H.; Groendijk, H.; Hol, W.G. The adaptability of the active site of trypanosomal triosephosphate isomerase as observed in the crystal structures of three different complexes. Proteins 1991, 10, 50-69. [CrossRef] [PubMed]

319. Wierenga, R.K.; Noble, M.E.; Vriend, G.; Nauche, S.; Hol, W.G. Refined $1.83 \AA$ A structure of trypanosomal triosephosphate isomerase crystallized in the presence of $2.4 \mathrm{M}$-ammonium sulphate. A comparison with the structure of the trypanosomal triosephosphate isomerase-glycerol-3-phosphate complex. J. Mol. Biol. 1991, 220, 995-1015. [CrossRef]

320. Noble, M.E.; Verlinde, C.L.; Groendijk, H.; Kalk, K.H.; Wierenga, R.K.; Hol, W.G. Crystallographic and molecular modeling studies on trypanosomal triosephosphate isomerase: A critical assessment of the predicted and observed structures of the complex with 2-phosphoglycerate. J. Med. Chem. 1991, 34, 2709-2718. [CrossRef] [PubMed]

321. Noble, M.E.; Zeelen, J.P.; Wierenga, R.K. Structures of the "open" and "closed" state of trypanosomal triosephosphate isomerase, as observed in a new crystal form: Implications for the reaction mechanism. Proteins 1993, 16, 311-326. [CrossRef] [PubMed]

322. Kishan, K.V.; Zeelen, J.P.; Noble, M.E.; Borchert, T.V.; Wierenga, R.K. Comparison of the structures and the crystal contacts of trypanosomal triosephosphate isomerase in four different crystal forms. Protein Sci. 1994, 3, 779-787. [PubMed]

323. Thanki, N.; Zeelen, J.P.; Mathieu, M.; Jaenicke, R.; Abagyan, R.A.; Wierenga, R.K.; Schliebs, W. Protein engineering with monomeric triosephosphate isomerase (monoTIM): The modelling and structure verification of a seven-residue loop. Protein Eng. 1997, 10, 159-167. [CrossRef] [PubMed]

324. Norledge, B.V.; Lambeir, A.M.; Abagyan, R.A.; Rottmann, A.; Fernandez, A.M.; Filimonov, V.V.; Peter, M.G.; Wierenga, R.K. Modeling, mutagenesis, and structural studies on the fully conserved phosphate-binding loop (loop 8) of triosephosphate isomerase: Toward a new substrate specificity. Proteins 2001, 42, 383-389. [CrossRef]

325. Casteleijn, M.G.; Alahuhta, M.; Groebel, K.; El-Sayed, I.; Augustyns, K.; Lambeir, A.M.; Neubauer, P.; Wierenga, R.K. Functional role of the conserved active site proline of triosephosphate isomerase. Biochemistry 2006, 45, 15483-15494. [CrossRef] [PubMed]

326. Salin, M.; Kapetaniou, E.G.; Vaismaa, M.; Lajunen, M.; Casteleijn, M.G.; Neubauer, P.; Salmon, L.; Wierenga, R.K. Crystallographic binding studies with an engineered monomeric variant of triosephosphate isomerase. Acta Crystallogr. D Biol. Crystallogr. 2010, 66, 934-944. [CrossRef] [PubMed] 
327. Maldonado, E.; Soriano-García, M.; Moreno, A.; Cabrera, N.; Garza-Ramos, G.; de Gómez-Puyou, M.; Gómez-Puyou, A.; Perez-Montfort, R. Differences in the intersubunit contacts in triosephosphate isomerase from two closely related pathogenic trypanosomes. J. Mol. Biol. 1998, 283, 193-203. [CrossRef] [PubMed]

328. Gao, X.G.; Maldonado, E.; Pérez-Montfort, R.; Garza-Ramos, G.; de Gómez-Puyou, M.T.; Gómez-Puyou, A.; Rodríguez-Romero, A. Crystal structure of triosephosphate isomerase from Trypanosoma cruzi in hexane. Proc. Natl. Acad. Sci. USA 1999, 96, 10062-10067. [CrossRef] [PubMed]

329. Téllez-Valencia, A.; Olivares-Illana, V.; Hernández-Santoyo, A.; Pérez-Montfort, R.; Costas, M.; Rodríguez-Romero, A.; López-Calahorra, F.; Tuena De Gómez-Puyou, M.; Gómez-Puyou, A. Inactivation of triosephosphate isomerase from Trypanosoma cruzi by an agent that perturbs its dimer interface. J. Mol. Biol. 2004, 341, 1355-1365. [CrossRef] [PubMed]

330. Olivares-Illana, V.; Rodríguez-Romero, A.; Becker, I.; Berzunza, M.; García, J.; Pérez-Montfort, R.; Cabrera, N.; López-Calahorra, F.; de Gómez-Puyou, M.T.; Gómez-Puyou, A. Perturbation of the dimer interface of triosephosphate isomerase and its effect on Trypanosoma cruzi. PLoS Negl. Trop. Dis. 2007, 1, e1. [CrossRef] [PubMed]

331. Zárate-Pérez, F.; Chánez-Cárdenas, M.E.; Vázquez-Contreras, E. The folding pathway of triosephosphate isomerase. Prog. Mol. Biol. Transl. Sci. 2008, 84, 251-267. [PubMed]

332. García-Torres, I.; Cabrera, N.; Torres-Larios, A.; Rodríguez-Bolaños, M.; Díaz-Mazariegos, S.; Gómez-Puyou, A.; Perez-Montfort, R. Identification of amino acids that account for long-range interactions in two triosephosphate isomerases from pathogenic trypanosomes. PLoS ONE 2011, 6, e18791. [CrossRef] [PubMed]

333. Aguirre, Y.; Cabrera, N.; Aguirre, B.; Pérez-Montfort, R.; Hernandez-Santoyo, A.; Reyes-Vivas, H.; Enríquez-Flores, S.; de Gómez-Puyou, M.T.; Gómez-Puyou, A.; Sanchez-Ruiz, J.M.; et al. Different contribution of conserved amino acids to the global properties of triosephosphate isomerases. Proteins 2014, 82, 323-335. [CrossRef] [PubMed]

334. Baiocco, P.; Colotti, G.; Franceschini, S.; Ilari, A. Molecular basis of antimony treatment in leishmaniasis. J. Med. Chem. 2009, 52, 2603-2612. [CrossRef] [PubMed]

335. Baiocco, P.; Ilari, A.; Ceci, P.; Orsini, S.; Gramiccia, M.; di Muccio, T.; Colotti, G. Inhibitory effect of silver nanoparticles on trypanothione reductase activity and Leishmania infantum proliferation. ACS Med. Chem. Lett. 2011, 2, 230-233. [CrossRef] [PubMed]

336. Ilari, A.; Baiocco, P.; Messori, L.; Fiorillo, A.; Boffi, A.; Gramiccia, M.; di Muccio, T.; Colotti, G. A gold-containing drug against parasitic polyamine metabolism: The X-ray structure of trypanothione reductase from Leishmania infantum in complex with auranofin reveals a dual mechanism of enzyme inhibition. Amino Acids 2012, 42, 803-811. [CrossRef] [PubMed]

337. Baiocco, P.; Poce, G.; Alfonso, S.; Cocozza, M.; Porretta, G.C.; Colotti, G.; Biava, M.; Moraca, F.; Botta, M.; Yardley, V.; et al. Inhibition of Leishmania infantum trypanothione reductase by azole-based compounds: A comparative analysis with its physiological substrate by X-ray crystallography. ChemMedChem 2013, 8, 1175-1183. [CrossRef] [PubMed]

338. Jones, D.C.; Ariza, A.; Chow, W.H.; Oza, S.L.; Fairlamb, A.H. Comparative structural, kinetic and inhibitor studies of Trypanosoma brucei trypanothione reductase with T. cruzi. Mol. Biochem. Parasitol. 2010, 169, 12-19. [CrossRef] [PubMed]

339. Patterson, S.; Alphey, M.S.; Jones, D.C.; Shanks, E.J.; Street, I.P.; Frearson, J.A.; Wyatt, P.G.; Gilbert, I.H.; Fairlamb, A.H. Dihydroquinazolines as a novel class of Trypanosoma brucei trypanothione reductase inhibitors: Discovery, synthesis, and characterization of their binding mode by protein crystallography. J. Med. Chem. 2011, 54, 6514-6530. [CrossRef] [PubMed]

340. Persch, E.; Bryson, S.; Todoroff, N.K.; Eberle, C.; Thelemann, J.; Dirdjaja, N.; Kaiser, M.; Weber, M.; Derbani, H.; Brun, R.; et al. Binding to large enzyme pockets: Small-molecule inhibitors of trypanothione reductase. ChemMedChem 2014, 9, 1880-1891. [CrossRef] [PubMed]

341. Lantwin, C.B.; Schlichting, I.; Kabsch, W.; Pai, E.F.; Krauth-Siegel, R.L. The structure of Trypanosoma cruzi trypanothione reductase in the oxidized and NADPH reduced state. Proteins 1994, 18, 161-173. [CrossRef] [PubMed]

342. Zhang, Y.; Bond, C.S.; Bailey, S.; Cunningham, M.L.; Fairlamb, A.H.; Hunter, W.N. The crystal structure of trypanothione reductase from the human pathogen Trypanosoma cruzi at $2.3 \AA$ A resolution. Protein Sci. 1996, 5, 52-61. [CrossRef] [PubMed] 
343. Bond, C.S.; Zhang, Y.; Berriman, M.; Cunningham, M.L.; Fairlamb, A.H.; Hunter, W.N. Crystal structure of Trypanosoma cruzi trypanothione reductase in complex with trypanothione, and the structure-based discovery of new natural product inhibitors. Structure 1999, 7, 81-89. [CrossRef]

344. Saravanamuthu, A.; Vickers, T.J.; Bond, C.S.; Peterson, M.R.; Hunter, W.N.; Fairlamb, A.H. Two interacting binding sites for quinacrine derivatives in the active site of trypanothione reductase: A template for drug design. J. Biol. Chem. 2004, 279, 29493-29500. [CrossRef] [PubMed]

345. Alphey, M.S.; König, J.; Fairlamb, A.H. Structural and mechanistic insights into type II trypanosomatid tryparedoxin-dependent peroxidases. Biochem. J. 2008, 414, 375-381. [CrossRef] [PubMed]

346. Piñeyro, M.D.; Pizarro, J.C.; Lema, F.; Pritsch, O.; Cayota, A.; Bentley, G.A.; Robello, C. Crystal structure of the tryparedoxin peroxidase from the human parasite Trypanosoma cruzi. J. Struct. Biol. 2005, 150, 11-22. [CrossRef] [PubMed]

347. Koh, C.Y.; Kim, J.E.; Napoli, A.J.; Verlinde, C.L.; Fan, E.; Buckner, F.S.; van Voorhis, W.C.; Hol, W.G. Crystal structures of Plasmodium falciparum cytosolic tryptophanyl-tRNA synthetase and its potential as a target for structure-guided drug design. Mol. Biochem. Parasitol. 2013, 189, 26-32. [CrossRef] [PubMed]

348. Merritt, E.A.; Arakaki, T.L.; Gillespie, R.; Napuli, A.J.; Kim, J.E.; Buckner, F.S.; van Voorhis, W.C.; Verlinde, C.L.; Fan, E.; Zucker, F.; et al. Crystal structures of three protozoan homologs of tryptophanyl-tRNA synthetase. Mol. Biochem. Parasitol. 2011, 177, 20-28. [CrossRef] [PubMed]

349. Larson, E.T.; Kim, J.E.; Castaneda, L.J.; Napuli, A.J.; Zhang, Z.; Fan, E.; Zucker, F.H.; Verlinde, C.L.; Buckner, F.S.; van Voorhis, W.C.; et al. The double-length tyrosyl-tRNA synthetase from the eukaryote Leishmania major forms an intrinsically asymmetric pseudo-dimer. J. Mol. Biol. 2011, 409, 159-176. [CrossRef] [PubMed]

350. Bhatt, T.K.; Khan, S.; Dwivedi, V.P.; Banday, M.M.; Sharma, A.; Chandele, A.; Camacho, N.; de Pouplana, L.R.; $\mathrm{Wu}$, Y.; Craig, A.G.; et al. Malaria parasite tyrosyl-tRNA synthetase secretion triggers pro-inflammatory responses. Nat. Commun. 2011, 2, 530. [CrossRef] [PubMed]

351. Artavanis-Tsakonas, K.; Weihofen, W.A.; Antos, J.M.; Coleman, B.I.; Comeaux, C.A.; Duraisingh, M.T.; Gaudet, R.; Ploegh, H.L. Characterization and structural studies of the Plasmodium falciparum ubiquitin and Nedd8 hydrolase UCHL3. J. Biol. Chem. 2010, 285, 6857-6866. [CrossRef] [PubMed]

352. Shaw, M.P.; Bond, C.S.; Roper, J.R.; Gourley, D.G.; Ferguson, M.A.; Hunter, W.N. High-resolution crystal structure of Trypanosoma brucei UDP-galactose 4'-epimerase: A potential target for structure-based development of novel trypanocides. Mol. Biochem. Parasitol. 2003, 126, 173-180. [CrossRef]

353. Dhatwalia, R.; Singh, H.; Oppenheimer, M.; Sobrado, P.; Tanner, J.J. Crystal structures of Trypanosoma cruzi UDP-galactopyranose mutase implicate flexibility of the histidine loop in enzyme activation. Biochemistry 2012, 51, 4968-4979. [CrossRef] [PubMed]

354. Führing, J.; Cramer, J.T.; Routier, F.H.; Lamerz, A.C.; Baruch, P.; Gerardy-Schahn, R.; Fedorov, R. Catalytic mechanism and allosteric regulation of UDP-glucose pyrophosphorylase from Leishmania major. ACS Catal. 2013, 3, 2976-2985. [CrossRef]

355. Urbaniak, M.D.; Collie, I.T.; Fang, W.; Aristotelous, T.; Eskilsson, S.; Raimi, O.G.; Harrison, J.; Navratilova, I.H.; Frearson, J.A.; van Aalten, D.M.; et al. A novel allosteric inhibitor of the uridine diphosphate $\mathrm{N}$-acetylglucosamine pyrophosphorylase from Trypanosoma brucei. ACS Chem. Biol. 2013, 8, 1981-1987. [CrossRef] [PubMed]

356. Larson, E.T.; Mudeppa, D.G.; Gillespie, J.R.; Mueller, N.; Napuli, A.J.; Arif, J.A.; Ross, J.; Arakaki, T.L.; Lauricella, A.; Detitta, G.; et al. The crystal structure and activity of a putative trypanosomal nucleoside phosphorylase reveal it to be a homodimeric uridine phosphorylase. J. Mol. Biol. 2010, 396, 1244-1259. [CrossRef] [PubMed]

357. Yuriev, E.; Holien, J.; Ramsland, P.A. Improvements, trands, and new ideas in molecular docking: 2012-2013 in review. J. Mol. Recognit. 2015, 28, 581-604. [CrossRef] [PubMed]

358. Ferreira, L.G.; dos Santos, R.N.; Oliva, G.; Andricopulo, A.D. Molecular docking and structure-based drug design strategies. Molecules 2015, 20, 13384-13421. [CrossRef] [PubMed]

359. Berry, M.; Fielding, B.; Gamieldien, J. Practical considerations in virtual screening and molecular docking. In Emerging Trends in Computational Biology, Bioinformatics, and Systems Biology; Tran, Q.N., Hamid, A.R., Eds.; Elsevier: Amsterdam, The Netherlands, 2015; pp. 487-502.

360. De Ruyck, J.; Brysbaert, G.; Blossey, R.; Lensink, M.F. Molecular docking as a popular tool in drug design, an in silico travel. Adv. Appl. Bioinform. Chem. 2016, 9, 1-11. [CrossRef] [PubMed] 
361. Yuriev, E.; Agostino, M.; Ramsland, P.A. Challenges and advances in computational docking: 2009 in review. J. Mol. Recognit. 2011, 24, 149-164. [CrossRef] [PubMed]

362. Yuriev, E.; Ramsland, P.A. Latest developments in molecular docking: 2010-2011 in review. J. Mol. Recognit. 2013, 26, 215-239. [CrossRef] [PubMed]

363. Irwin, J.J.; Shoichet, B.K. Docking screens for novel ligands conferring new biology. J. Med. Chem. 2016, 59, 4103-4120. [CrossRef] [PubMed]

364. Venkatesan, S.K.; Saudagar, P.; Shukla, A.K.; Dubey, V.K. Screening natural products database for identification of potential antileishmanial chemotherapeutic agents. Interdiscip. Sci. 2011, 3, 217-231. [CrossRef] [PubMed]

365. Herrmann, F.C.; Schmidt, T.J. In silico screening of natural product databases reveals new potential leads against neglected diseases. Planta Med. 2013, 79. [CrossRef]

366. Buckingham, J. (Ed.) Dictionary of Natural Products on DVD; CRC Press: Boca Raton, FL, USA, 2016.

367. Napralert. Natural Products Alert. Available online: http://napralert.org (accessed on 16 August 2016).

368. ZINC ${ }^{12}$. Bioinformatics and Chemical Informatics Research Center, Department of Pharmaceutical Chemistry, University of California: San Francisco, CA, USA. Available online: http://zinc.docking.org/ browse/catalogs/natural-products (accessed on 16 August 2016).

369. Morris, G.M.; Huey, R.; Lindstrom, W.; Sanner, M.F.; Belew, R.K.; Goodsell, D.S.; Olson, A.J. Autodock4 and AutoDockTools4: Automated docking with selective receptor flexiblity. J. Comput. Chem. 2009, 16, 2785-2791. [CrossRef] [PubMed]

370. Thomsen, R.; Christensen, M.H. MolDock: A new technique for high-accuracy molecular docking. J. Med. Chem. 2006, 49, 3315-3321. [CrossRef] [PubMed]

371. Friesner, R.A.; Banks, J.L.; Murphy, R.B.; Halgren, T.A.; Klicic, J.J.; Mainz, D.T.; Repasky, M.P.; Knoll, E.H.; Shaw, D.E.; Shelley, M.; et al. Glide: A new approach for rapid, accurate docking and scoring. 1. Method and assessment of docking accuracy. J. Med. Chem. 2004, 47, 1739-1749. [CrossRef] [PubMed]

372. Trott, O.; Olson, A.J. AutoDock Vina: Improving the speed and accuracy of docking with a new scoring function, efficient optimization, and multithreading. J. Comput. Chem. 2010, 31, 455-461. [CrossRef] [PubMed]

373. Jain, A.N. Surflex-Dock 2.1: Robust performance from ligand energetic modeling, ring, flexibility, and knowledge-based search. J. Comput. Aided Mol. Des. 2007, 21, 281-306. [CrossRef] [PubMed]

374. Ogungbe, I.V.; Ng, J.D.; Setzer, W.N. Interactions of antiparasitic alkaloids with Leishmania protein targets: A molecular docking analysis. Future Med. Chem. 2013, 5, 1777-1799. [CrossRef] [PubMed]

375. Ogungbe, I.V.; Setzer, W.N. In-silico Leishmania target selectivity of antiparasitic terpenoids. Molecules 2013, 18, 7761-7847. [CrossRef] [PubMed]

376. Kumar, M.; Dagar, A.; Gupta, V.K.; Sharma, A. In silico docking studies of bioactive natural plant products as putative DHFR antagonists. Med. Chem. Res. 2014, 23, 810-817. [CrossRef]

377. Ogungbe, I.V.; Erwin, W.R.; Setzer, W.N. Antileishmanial phytochemical phenolics: Molecular docking to potential protein targets. J. Mol. Graph. Model. 2014, 48, 105-117. [CrossRef] [PubMed]

378. Bernal, F.A.; Coy-Barrera, E. In-silico analyses of sesquiterpene-related compounds on selected Leishmania enzyme-based targets. Molecules 2014, 19, 5550-5569. [CrossRef] [PubMed]

379. Setzer, W.N.; Ogungbe, I.V. In-silico investigation of antitrypanosomal phytochemicals from Nigerian medicinal plants. PLoS Negl. Trop. Dis. 2012, 6, e1727. [CrossRef] [PubMed]

380. McCulley, S.F.; Setzer, W.N. An in-silico investigation of anti-Chagas phytochemicals. Curr. Clin. Pharmacol. 2014, 9, 205-257. [CrossRef] [PubMed]

381. Melo, T.S.; Gattass, C.R.; Soares, D.C.; Cunha, M.R.; Ferreira, C.; Tavares, M.T.; Saraiva, E.; Parise-Filho, R.; Braden, H.; Delorenzi, J.C. Oleanolic acid (OA) as an antileishmanial agent: Biological evaluation and in silico mechanistic insights. Parasitol. Int. 2016, 65, 227-237. [CrossRef] [PubMed]

382. Dos Reis, M.B.G.; Manjolin, L.C.; Maquiaveli, C.D.C.; Santos-Filho, O.A.; da Silva, E.R. Inhibition of Leishmania (Leishmania) amazonensis and rat arginases by green tea EGCG, (+)-catechin and (2)-epicatechin: A comparative structural analysis of enzyme-inhibitor interactions. PLoS ONE 2013, 8, e78387. [CrossRef] [PubMed]

383. Venkatesan, S.K.; Saudagar, P.; Dubey, V.K. Identification of novel inhibitor of trypanothione synthase from two Leishmania species: Comparative in silico analysis. J. Protein Proteom. 2011, 2, 41-48. 
384. Krauth-Siegel, R.L.; Inhoff, O. Parasite-specific trypanothione reductase as a drug target molecule. Parasitol. Res. 2003, 90 (Suppl. 2), S77-S85. [CrossRef] [PubMed]

385. Gundampati, R.K.; Jagannadham, M.V. Molecular docking based inhibition of trypanothione reductase activity of taxifolin novel target for antileishmanial activity. J. Appl. Pharmaceut. Sci. 2012, 2, 133-136. [CrossRef]

386. Ribeiro, F.F.; Junior, F.J.B.M.; da Silva, M.S.; Scotti, M.T.; Scotti, L. Computational and investigative study of flavonoids against Trypanosoma cruzi and Leishmania spp. Nat. Prod. Commun. 2015, 10, 917-920. [PubMed]

387. Lipinski, C.A.; Lombardo, F.; Dominy, B.W.; Feeney, P.J. Experimental and computational approaches to estimate solubility and permeability in drug discovery and development settings. Adv. Drug Deliv. Rev. 2001, 46, 3-26. [CrossRef]

388. Gundampati, R.K.; Chandrasekaran, S.; Jagannadham, M.V. Molecular docking study on the interaction between trypanothione reductase and mangiferin for antileishmanial activity. Bangladesh J. Pharmacol. 2013, 8, 40-43.

389. Chauhan, R. In Silico Approach towards Finding Inhibitory Effect of Phytochemicals on Trypanothione Reductase in Leishmania donovani. Master's Thesis, National Institute of Technology, Orissa, India, 2014.

390. Venkatesan, S.K.; Dubey, V.K. Footprinting of inhibitor interactions of in silico identified inhibitors of trypanothione reductase of Leishmania parasite. Sci. World J. 2012, 2012, 963658. [CrossRef] [PubMed]

391. Lavie, Y.; Harel-Orbital, T.; Gaffield, W.; Liscovitch, M. Inhibitory effect of steroidal alkaloids on drug transport and multidrug resistance in human cancer cells. Anticancer Res. 2001, 21, 1189-1194. [PubMed]

392. Medina, J.M.; Rodrigues, J.C.; de Souza, W.; Atella, G.C.; Barrabin, H. Tomatidine promotes the inhibition of 24-alkylated sterol biosynthesis and mitochondrial dysfunction in Leishmania amazonensis promastigotes. Parasitology 2012, 139, 1253-1265. [CrossRef] [PubMed]

393. Ogungbe, I.V.; Setzer, W.N. Comparative molecular docking of antitrypanosomal natural products into multiple Trypanosoma brucei drug targets. Molecules 2009, 14, 1513-1536. [CrossRef] [PubMed]

394. Izumi, E.; Ueda-Nakamura, T.; Dias Milho, B.P.; Veiga Júnior, V.F.; Vataru Nakamura, C. Natural products and Chagas' disease: A review of plant compounds studied for activity against Trypanosoma cruzi. Nat. Prod. Rep. 2011, 28, 809-823. [CrossRef] [PubMed]

395. Argüelles, A.J.; Cordell, G.A.; Maruenda, H. Molecular docking and binding mode analysis of plant alkaloids as in vitro and in silico inhibitors of trypanothione reductase from Trypanosoma cruzi. Nat. Prod. Commun. 2016, 11, 57-62. [PubMed]

396. Asthana, S.; Agarwal, T.; Banerjee, I.; Ray, S.S. In silico screening to elucidate the therapeutic potentials of asparagamine A. Int. J. Pharm. Pharmaceut. Sci. 2014, 6, 247-253.

397. Saha, D.; Sharma, A. Docking-based screening of natural product database in quest for dual site inhibitors of Trypanosoma cruzi trypanothione reductase (TcTR). Med. Chem. Res. 2015, 24, 316-333. [CrossRef]

398. Sahi, S.; Tewatia, P.; Shosal, S. Leishmania donovani pteridine reductase 1: Comparative protein modeling and protein-ligand interaction studies of the leishmanicidal constituents isolated from the fruits of Piper longum. J. Mol. Model. 2012, 18, 5065-5073. [CrossRef] [PubMed]

399. Herrmann, F.C.; Lenz, M.; Jose, J.; Kaiser, M.; Brun, R.; Schmidt, T.J. In silico identification and in vitro activity of novel natural inhibitors of Trypanosoma brucei glyceraldehyde-3-phosphate dehydrogenase. Molecules 2015, 20, 16154-16169. [CrossRef] [PubMed]

400. Scotti, L.; Ishiki, H.; Mondonça Júnior, F.J.B.; da Silva, M.S.; Scotti, M.T. In-silico analyses of natural products on Leishmania enzyme targets. Mini Rev. Med. Chem. 2015, 15, 253-269. [CrossRef] [PubMed]

401. Rakesh, N.R.; Pradeep, S. Comparative genomic studies and in-silico strategies on Leishmania braziliensis, Leishmania infantum and Leishmania major: Conserved features, putative functions and potential drug target. Int. J. Appl. Sci. Biotechnol. 2013, 1, 62-66. [CrossRef]

402. Soares, M.B.P.; Silva, C.V.; Bastos, T.M.; Guimarães, E.T.; Figueira, C.P.; Smirlis, D.; Azevedo, W.F., Jr. Anti-Trypanosoma cruzi activity of nicotinamide. Acta Trop. 2012, 122, 224-229. [CrossRef] [PubMed]

403. Sacconnay, L.; Angleviel, M.; Randazzo, G.M.; Queiroz, M.M.F.; Queiroz, E.F.; Wolfender, J.L.; Carrupt, P.A.; Nurisso, A. Computational studies on sirtuins from Trypansomoma cruzi: Structures, conformations and interactions with phytochemicals. PLoS Negl. Trop. Dis. 2014, 8, e2689. [CrossRef] [PubMed]

404. Looker, D.L.; Berens, R.L.; Marr, J.J. Purine metabolism in Leishmania donovani amastigotes and promastigotes. Mol. Biochem. Parasitol. 1983, 9, 15-28. [CrossRef] 
405. Kar, R.K.; Ansari, M.Y.; Suryadevara, P.; Sahoo, B.R.; Sahoo, G.C.; Dikhit, M.R.; Das, P. Computational elucidation of structural basis for ligand binding with Leishmania donovani adenosine kinase. BioMed Res. Int. 2013, 2013, 609289. [CrossRef] [PubMed]

406. Chakrabarti, R.; Rawat, P.S.; Cooke, B.M.; Coppel, R.L.; Patankar, S. Cellular effects of curcumin on Plasmodium falciparum include disruption of microtubules. PLoS ONE 2013, 8, e57302. [CrossRef] [PubMed]

407. Dahlström, S.; Veiga, M.I.; Ferreira, P.; Mårtensson, A.; Kaneko, A.; Andersson, B.; Björkman, A.; Gil, J.P. Diversity of the sarco/endoplasmic reticulum $\mathrm{Ca}^{2+}$-ATPase orthologue of Plasmodium falciparum (PfATP6). Infect. Genet. Evol. 2008, 8, 340-345. [CrossRef] [PubMed]

408. Jung, M.; Kim, H.; Nam, K.Y.; No, K.T. Three-dimensional structure of Plasmodium falciparum Ca ${ }^{2+}$-ATPase (PfATP6) and docking of artemisinin derivatives to PfATP6. Bioorg. Med. Chem. Lett. 2005, 15, 2994-2997. [CrossRef] [PubMed]

409. Ji, H.F.; Shen, L. Interactions of curcumin with the PfATP6 model and the implications for its antimalarial mechanism. Bioorg. Med. Chem. Lett. 2009, 19, 2453-2455. [CrossRef] [PubMed]

410. Shukla, A.; Singh, A.; Singh, A.; Pathak, L.P.; Shrivastava, N.; Tripathi, P.K.; Singh, M.P.; Singh, K. (Inhibition of P. falciparum PfATP6 by curcumin and its derivatives: A bioinformatics study. Cell. Mol. Biol. 2012, 58, 182-186. [PubMed]

411. Bousejra-El Garah, F.; Stigliani, J.L.; Coslédan, F.; Meunier, B.; Robert, A. Docking studies of structurally diverse antimalarial drugs targeting PfATP6: No correlation between in silico binding affinity and in vitro antimalarial activity. ChemMedChem 2009, 4, 1469-1479. [CrossRef] [PubMed]

412. Brown, W.M.; Yowell, C.A.; Hoard, A.; Vander Jagt, T.A.; Hunsaker, L.A.; Deck, L.M.; Royer, R.E.; Piper, R.C.; Dame, J.B.; Makler, M.T.; et al. Comparative structural analysis and kinetic properties of lactate dehydrogenases from the four species of human malarial parasites. Biochemistry 2004, 43, 6219-6229. [CrossRef] [PubMed]

413. Tegar, M.; Purnomo, H. Tea leaves extracted as anti-malaria based on molecular docking PLANTS. Proc. Environ. Sci. 2013, 17, 188-194. [CrossRef]

414. Kalani, K.; Agarwal, J.; Alam, S.; Khan, F.; Pal, A.; Srivastava, S.K. In silico and in vivo anti-malarial studies of 18ß-glycyrrhetinic acid from Glychrrhiza glabra. PLoS ONE 2013, 8, e74761. [CrossRef] [PubMed]

415. Lauinger, I.L.; Vivas, L.; Perozzo, R.; Stairiker, C.; Tarun, A.; Zloh, M.; Zhang, X.; Xu, H.; Tonge, P.J.; Franzblau, S.G.; et al. Potential of lichen secondary metabolites against Plasmodium liver stage parasites with FAS-II as the potential target. J. Nat. Prod. 2013, 76, 1064-1070. [CrossRef] [PubMed]

416. Tallorin, L.; Durrant, J.D.; Nguyen, Q.G.; McCammon, J.A.; Burkart, M.D. Celastrol inhibits Plasmodium falciparum enoyl-acyl carrier protein reductase. Bioorg. Med. Chem. 2014, 22, 6053-6061. [CrossRef] [PubMed]

417. Wadhwa, P.; Saha, D.; Sharma, A. Combined 3D-QSAR and molecular docking study for identification of diverse natural products as potent Pf ENR inhibitors. Curr. Comput. Aided Drug Des. 2015, 11, $245-257$. [CrossRef] [PubMed]

418. Gupta, C.L.; Akhtar, S.; Kumar, N.; Ali, J.; Pathak, N.; Bajpai, P. In silico elucidation and inhibition studies of selected phytoligands against mitogen-activated protein kinases of protozoan parasites. Inderdiscip. Sci. Comput. Life Sci. 2016, 8, 41-52. [CrossRef] [PubMed]

419. García-Sosa, A.T.; Maran, U.; Hetényi, C. Molecular property filters describing pharmacokinetics and drug binding. Curr. Med. Chem. 2012, 19, 1646-1662. [CrossRef] [PubMed]

420. Tian, S.; Wang, J.; Li, Y.; Li, D.; Xu, L.; Hou, T. The application of in silico drug-likeness predictions in pharmaceutical research. Adv. Drug Deliv. Rev. 2015, 86, 2-10. [CrossRef] [PubMed]

421. Hou, T.; Wang, J. Structure-ADME relationship: Still a long way to go? Expert. Opin. Drug Metab. Toxicol. 2008, 4, 759-770. [CrossRef] [PubMed]

422. Valerio, L.G. In silico toxicology for the pharmaceutical sciences. Toxicol. Appl. Pharmacol. 2009, 241, 356-370. [CrossRef] [PubMed]

(C) 2016 by the authors; licensee MDPI, Basel, Switzerland. This article is an open access article distributed under the terms and conditions of the Creative Commons Attribution (CC-BY) license (http://creativecommons.org/licenses/by/4.0/). 